\title{
CITOLOGIA DE HÍBRIDOS SOMÁTICOS DE Passiflora spp. OBTIDOS POR FUSÃO DE PROTOPLASTOS
}

\author{
LUCIANA VEIGA BARBOSA \\ Engenheira Agrônoma
}

Orientadora: Profa. Dra. Maria Lúcia Carneiro Vieira

Tese apresentada à Escola Superior de Agricultura 'Luiz de Queiroz', Universidade de São Paulo, para a obtenção do título de Doutor em Agronomia, Área de Concentração: Genética e Melhoramento de Plantas.

PIRACICABA

Estado de São Paulo - Brasil Abril - 1998 
Dados Internacionais de Catalogação na Publicação (CIP)

DIVISÃO DE BIBLIOTECA E DOCUMENTAÇÃO - Campus "Luiz de Queiroz"/USP

Barbosa, Luciana Veiga

Citologia de híbridos somáticos de Passifora spp. obtidos por fusão de protoplastos / Luciana Veiga Barbosa. - - Piracicaba, 1998.

127 p. : il.

Dissertação (doutorado) -- Escola Superior de Agricultura Luiz de Queiroz, 1998. Bibliografia.

1. Citologia vegetal 2. Fusão de protoplasto 3. Hibridação somática 4. Maracujá 5. Meiose 6. Melhoramento genético vegetal I. Título 


\title{
CITOLOGIA DE HÍBRIDOS SOMÁTICOS DE Passiflora spp. OBTIDOS POR FUSÃO DE PROTOPLASTOS
}

\author{
LUCIANA VEIGA BARBOSA
}

Aprovada em: 13.04.1998

Comissão julgadora

Profa. Dra. Maria Lúcia Carneiro Vieira ESALQ/USP

Profa. Dra. Lisete Chamma Davide UFLA/MG

Prof. Dr. Francisco de Assis Alves Mourão Filho ESALQ/USP

Dr. Mário Augusto Pinto da Cunha EMBRAPA/CNPMF

Dr. Rui Pereira Leite IAPAR/PR

$$
\text { MonialuciaCarneino Vilira }
$$

Profa. Dra. MARIA LÚCIA CARNEIRO VIEIRA (orientadora) 
Ao meu pai, dedico 


\section{AGRADECIMENTOS}

Ao Departamento de Genética da ESALQ/USP, pela possibilidade de realizar o curso;

À Profa. Dra. Maria Lúcia Cameiro Vieira, pela orientação, amizade, apoio e confiança;

Ao Prof. Dr. João Carlos de Oliveira, do Departamento de Fitotecnia da Faculdade de Ciências Agrárias e Veterinárias de Jaboticabal/UNESP$\mathrm{SP}$, pelos ensinamentos e auxílio na parte prática;

Aos colegas do Curso de Pós-Graduação em Genética e Melhoramento de Plantas, da ESALQ/USP;

Ao CNPq, pela concessão da bolsa de doutorado;

À FAPESP, pelo auxílio financeiro que permitiu a condução deste trabalho;

Aos colegas de laboratório, especialmente ao Carlos Alberto de Oliveira, pelo apoio técnico e carinho nessa convivência de quatro anos;

Aos colegas Augusto, Gilberto, Cláudio e Rainner, pelo auxílio nas análises estatísticas;

À Vera Maria Quecini, pelo auxílio na elaboração do summary;

À minha amiga especial, Marcela, pela longa convivência de três anos, pelo respeito, carinho e compreensão;

Às minhas amigas, Márcia, Cristiane, Daniele, Cléo, Nívea e Rô, pelo apoio e carinho;

A todos que, de uma forma direta ou indireta, contribuíram para a execução deste trabalho. 


\section{SUMÁRIO}

LISTA DE FIGURAS

LISTA DE TABELAS...........................................................................

RESUMO.................................................................................................... xii

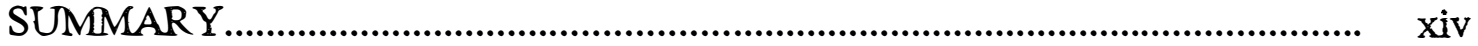

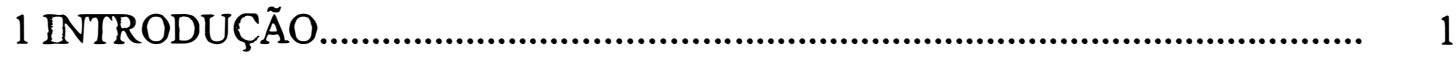

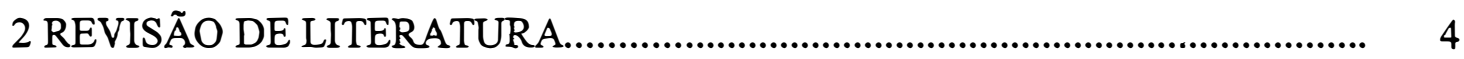

2.1 Botânica........................................................................................................... 4

2.2 Importância econômica....................................................................... 5

2.3 Principais problemas da cultura.......................................................... 6

2.4 Melhoramento genético.................................................................. 9

2.5 Melhorarnento assistido por biotecnologia......................................... 13

2.6 Citogenética de híbridos somáticos.................................................. 15

2.6.1 Mitose de híbridos somáticos.................................................... 16

2.6.2 Meiose e viabilidade do grão de pólen em híbridos somáticos..................................................................................... 20

2.7 Hibridação somática no maracujazeiro.................................................... 23

2.8 Efeito da poliploidia nas células da epiderme foliar dos híbridos somáticos.

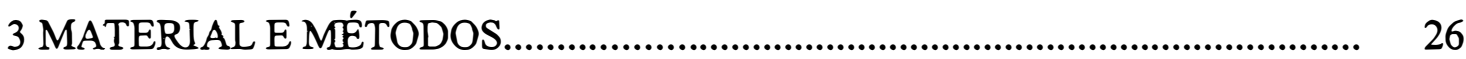

3.1 Material vegetal e local de plantio.................................................... 26

3.2 Descrição dos parentais................................................................. 29

3.3 Morfologia foliar e florescimento; Comportamento cromossômico na meiose.

3.4 Análise da viabilidade do grão de pólen............................................. 33

3.5 Efeito da poliploidia nas células da epiderme foliar dos híbridos somáticos. 
4.1 Morfologia foliar e florescimento............................................. 36

4.2 Comportamento cromossômico na meiose........................................ 44

4.2.1 Análise meiótica das espécies parentais (grupo 1).................. 44

4.2.2 Análise meiótica dos híbridos somáticos................................ 47

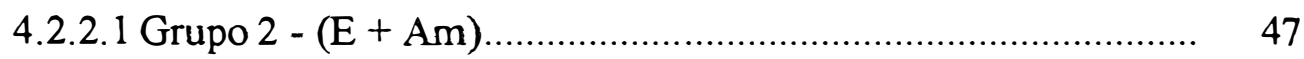

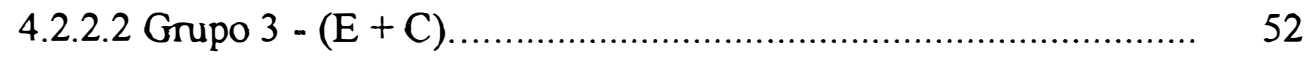

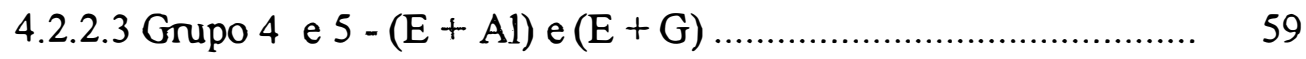

4.3 Análise da viabilidade do grão de pólen.......................................... 66

4.4 Efeito da poliploidia nas células da epiderme foliar dos híbridos

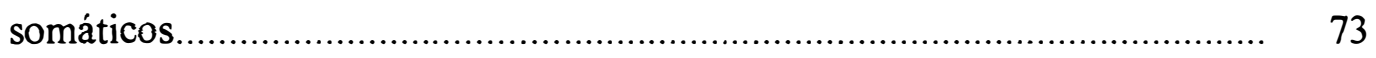

5 CONCLUSÕES

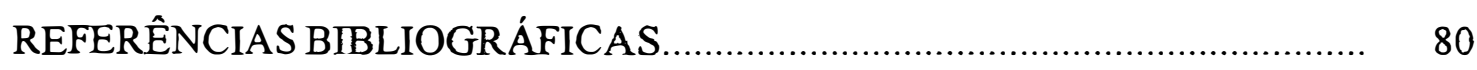

ANEXO 


\section{LISTA DE FIGURAS}

1. Incidência da morte prematura das plantas (A) e da bacteriose causada por Xanthomonas campestris pv. passiflorae (B), em P. edulis Sims f. flavicarpa Deg.

2. Híbridos somáticos de Passiflora spp. A. $(\mathrm{E}+\mathrm{Am}) \# 28$ em fase de aclimatação na casa de vegetação. B. $(E+C)$ no campo experimental da ESALQ/USP, em Piracicaba, SP.

3. Morfologia floral em Passiflora spp. A. P. edulis Sims f. flavicarpa, B. P. cincinnata, C. P. giberti, D. P. amethystina e E. P. alata.

4.1. Aspectos da morfologia foliar em P. edulis Sims f. flavicarpa (E), $P$. amethystina (Am), P. cincinnata $(\mathrm{C})$ e dos respectivos híbridos somáticos (E + $\mathrm{Am}) \mathrm{e}(\mathrm{E}+\mathrm{C})$

4.2. Aspectos da morfologia foliar em P. edulis Sims f. flavicarpa (E), P. alata (Al), P. giberti $(\mathrm{G})$ e dos respectivos híbridos somáticos $(\mathrm{E}+\mathrm{Al})$ e $(\mathrm{E}+$ G).

5. Morfologia floral dos híbridos somáticos. A. $(E+G), B .(E+A m)$, C. $(E+$ $\mathrm{Al})$ e, D. $(\mathrm{E}+\mathrm{C})$.

6. Desenvolvimento do fruto em $(E+C) \# 25$ no qual se observa a formação de sementes anormais.

7. Meiose em Passiflora spp. A. P. edulis Sims f. flavicarpa, B. P. alata, C. P. cincinnata, D. P. giberti e, E. P. amethystina no estágio de diacinese. Dois bivalentes associados ao nucléolo são indicados por setas em B, C e D. Barra = $10 \mu \mathrm{m}$.

8. Meiose em $(E+A m) \#$ 12. A. Segregação de 14 bivalentes e dois tetravalentes (setas). B. Segregação de dois univalentes, 15 bivalentes e um tetravalente (seta). C. presença de cromossomo atrasado (seta) e, D. ocorrência de ponte cromossômica (seta). Barra $=10 \mu \mathrm{m}$.

9. A e B. Meiose em $(E+C) \# 25$ e \# 14, ambos com segregação de 18 bivalentes. C. Presença de pontes cromossômicas (seta). D. Ocorrência de cromátide atrasada (seta). E. Presença de cromossomos com ascenção precoce (seta). F. Ocorrência de ponte cromatídica (seta).Barra $=10 \mu \mathrm{m}$.

10. A. Tétrades normais em $(E+C) \# 14$. B. presença de micronúcleos em $(E+$

C) \#25 (seta). Barra $=10 \mu \mathrm{m}$ 
11. Diferentes fases da meiose em $(E+G) \#$ 05. A. Paquíteno. B e $C$. Segregação de 9 bivalentes. D. Presença de cromossomos atrasados em metáfase I (seta). E. Ponte cromossômica em anáfase I (seta). F. Telófase I. G. Prófase II. H. Metáfase II. I. Cromátide atrasada em anáfase II (seta). J. Telófase II. K. Tétrade. L. Grão de pólen. Barra $=10 \mu \mathrm{m}$.

12. Meiose em $(E+A l) \#$ 06. A. Segregação de 9 bivalentes. B. Ponte cromossômica (seta). C. Cromossomo atrasado (seta). D. Ponte cromatídica. (seta). Barra $=10 \mu \mathrm{m}$.

13. A e B. Viabilidade do grão de pólen em $(E+A m) \# 13$ e \# 28, respectivamente. V. Grão de pólen viável. I. Grão de pólen inviável. Barra = $100 \mu \mathrm{m}$.

14. Correlações(r) entre viabilidade média do grão de pólen e irregularidades meióticas observadas em $P$. edulis Sims f. flavicarpa (edu), P. amethystina (am) e respectivos híbridos somáticos $(\mathrm{E}+\mathrm{Am}) \# 12, \# 13$, \# 28 e \# 35

15. Correlações(r) entre viabilidade média do grão de pólen e irregularidades meióticas observadas em $P$. edulis Sims f. flavicarpa (edu), P. cincinnata (cin) e respectivos híbridos somáticos $(\mathrm{E}+\mathrm{C})$ \# 14 e \#25.

16. Aspecto geral das células guarda de estômatos. A. P. edulis Sims $\mathrm{f}$. flavicarpa. B. P. cincinnata. C. $(\mathrm{E}+\mathrm{C}) \# 14 \mathrm{e}, \mathrm{D} .(\mathrm{E}+\mathrm{C}) \# 25$ Barra $=30 \mu \mathrm{m} \ldots$ 


\section{LISTA DE TABELAS}

1. Lista das espécies parentais $P$. edulis Sims f. flovicarpa (E), P. cincinnata Página (C), P. amethystina (Am), P. giberti(G) e P. alata (Al), dos respectivos híbridos somáticos e grau de ploidia na fase de seleção

2. Grupos genotípicos considerando as espécies parentais e respectivos híbridos somáticos

3. Avaliação da época de florescimento nas cinco espécies de Passiflora e respectivos híbridos somáticos nos anos de 1995/96 e 1996/97 (ESALQ/USP, Piracicaba/SP).

4. Análise meiótica de $P$. edulis Sims f. flavicarpa, P. amethystina, $P$. alata, $P$. cincinnata, $P$. giberti evidenciando cromossomos atrasados, com ascenção precoce e pontes anafásicas. Dados em porcentagem (\%)

5. Análise meiótica das plantas híbridas, $(E+A m) \# 12$ \# \# 13 , \# 28 e \# 35 evidenciando cromossomos atrasados e pontes anafásicas. Dados em porcentagem (\%).

6. Segregações meióticas dos híbridos somáticos $(E+A m) \# 12$, \# 13, \# 28 e \# 35. Número de células analisadas $=30$. Dados em porcentagem $(\%)$.

7. Análise meiótica de híbridos somáticos $(E+C) \# 14$ e $(E+C) \# 25$, evidenciando cromossomos atrasados ou com ascenção precoce e pontes anafásicas. Dados em porcentagem (\%)

8. Segregações observadas na meiose dos híbridos somáticos $(E+C) \# 14$ e $(E$ $+\mathrm{C})$ \# \#25. Dados em porcentagem (\%)..

9. Análise de esporócitos $(E+C) \# 14$ e $(E+C) \# 25$, evidenciando a ocorrência de micronúcleos. Dados em porcentagem (\%)

10. Análise meiótica dos híbridos somáticos $(\mathrm{E}+\mathrm{G}) \# 05$, \# 08, \#23 e \#36 e dos híbridos $(\mathrm{E}+\mathrm{Al}) \# 06, \# 17$ e \# 31, evidenciando cromossomos atrasados e pontes anafásicas. Dados em porcentagem $(\%)$.

11. Segregações meióticas nos híbridos somáticos $(E+G) \# 05$, \# 08, \# 23 e $\# 36$, $(\mathrm{E}+\mathrm{Al}) \# 06$, \# 17 e \#31. Número de células analisadas $=30$

12. Porcentagem de viabilidade do grão de pólen (diagonal à esquerda) e teste $\mathrm{t}$ em $P$. edulis Sims f. flavicarpa (E), P. amethystina (Am) e, respecticvos híbridos somáticos $(\mathrm{E}+\mathrm{Am}) \# 12$, \# 28, \# 28 e \#35. 
13. Porcentagem de viabilidade do grão de pólen (diagonal à esquerda) e teste $\mathrm{t}$ em $P$. edulis Sims f. flavicarpa (E), P. cincinnata (C) e, respecticvos híbridos somáticos $(\mathrm{E}+\mathrm{C})$ \# 14 e \# 25

14. Porcentagem de viabilidade do grão de pólen (diagonal à esquerda) e teste $\mathrm{t}$ para comparação das médias de em $P$. edulis Sims f. flavicarpa (E), P. giberti (G) e, respecticvos híbridos somáticos $(E+G) \# 05$, \# 08, \# 23 e \# 36 . .

15. Porcentagem de viabilidade do grão de pólen (diagonal à esquerda) e teste $\mathrm{t}$ para comparação das médias de em $P$. edulis Sims f. flavicarpa (E), P. alata (Al) e, respectivos híbridos somáticos $(\mathrm{E}+\mathrm{Al}) \# 06, \# 17$ e \# 31

16. Teste Tukey para comparação de médias da área $\left(\mu \mathrm{m}^{2}\right)$ e número médio de estômatos entre diplóides $P$. edulis Sims f. flavicarpa (E) e $P$. amethystina (Am), e poliplóides $(E+A m) \# 12$, \# 28, \# 28 e \# 35 .

17. Teste Tukey para comparação de médias da área $\left(\mu \mathrm{m}^{2}\right)$ e número médio de estômatos $P$. edulis Sims f. flavicarpa (E) e P. cincinnata (C), e poliplóides (E + C) \# 14 e \# 25 .

18. Teste Tukey para comparação de médias da área $\left(\mu^{2}\right)$ e número médio de estômatos entre diplóides $P$. edulis Sims f. flavicarpa (E) e $P$. giberti (G), e poliplóides $(E+G) \# 05$, \# 08, \# 23 e \# 36

19. Teste Tukey para comparação de médias da área $\left(\mu \mathrm{m}^{2}\right)$ e número médio de estômatos entre $P$. edulis Sims f. flavicarpa $(\mathrm{E})$ e $P$. alata $(\mathrm{Al})$, e poliplóides (E $+\mathrm{Al}) \# 06, \# 17$ e \# 31 


\section{RESUMO}

\section{Autora: Luciana Veiga Barbosa}

Orientadora: Profa. Dra. Maria Lúcia Carneiro Vieira

O Brasil é considerado o maior produtor mundial de maracujá, com uma área aproximada de 33.000 ha. No entanto, apresenta baixa produtividade ( 8 a 10 t/ha) que é motivada principalmente por problemas fitossanitários. Programas de melhoramento genético, via hibridação sexual, visando introgredir genes de resistência a doenças presentes em espécies selvagens, têm sido conduzidos porém, apresentam resultados modestos. Isso se deve ao fato das espécies do gênero Passiflora, além de serem autoicompatíveis, apresentarem incompatibilidade cruzada, o que limita o uso da hibridação sexual. Uma alternativa para contornar essa barreira é a hibridação somática, via fusão de protoplastos. Dando continuidade à uma linha de pesquisa desenvolvida no Departamento de Genética (ESALQ/USP), esta tese se propôs a apresentar estudos sobre o desenvolvimento vegetativo e reprodutivo de alguns híbridos somáticos obtidos entre a espécie cultivada $P$. edulis Sims. f. flavicarpa Deg. (E) e, espécies portadoras de genes de resistência a doenças, $P$. alata $(\mathrm{Al}), P$. amethystina $(\mathrm{Am}), P$. cincinnata $(\mathrm{C}) \mathrm{e}$, $P$. giberti (G), todas com $2 \mathrm{n}=2 \mathrm{x}=18$ cromossomos. As análises citológicas confirmaram a natureza híbrida para $(E+A m)$ e $(E+C)$, pois as plantas dessas combinações apresentaram $2 \mathrm{n}=4 \mathrm{x}=36$ cromossomos. Alterações meióticas como a presença de cromossomos e cromátides atrasadas, cromossomos com ascenção precoce e pontes anafásicas foram observadas. Os híbridos $(\mathrm{E}+\mathrm{Am})$ apresentaram configurações do tipo univalentes, bivalentes 
e tetravalentes, indicando a ocorrência de crossing-over entre cromossomos homeólogos. Todas as plantas híbridas apresentaram elevados valores de viabilidade do grão de pólen, acima de $70 \%$. Os híbridos $(\mathrm{E}+\mathrm{C})$ mostraram, igualmente, irregularidades meióticas e configurações do tipo univalentes e tetravalentes, indicando também a ocorrência de pareamento homeólogo. Entretanto, cerca de $70 \%$ das células apresentaram 18 bivalentes, o que explica os altos valores de viabilidade do grão de pólen observados. Os híbridos $(E+A l)$ e $(E+G)$ mostraram $2 n=2 x=18$ cromossomos, foram fenotipicamente semelhantes aos parentais selvagens, com meiose regular e elevada viabilidade do grão de pólen. Nesse caso, provavelmente, ocorreu eliminação dos cromossomos do parental cultivado. Foi estudado o efeito da poliploidia nas células da epiderme inferior das plantas híbridas $(E+A m)$ e $(E$ + C). Pôde-se observar que, à medida que ocorre um incremento no nível de ploidia nas plantas, essas apresentam uma maior área e menor número de estômatos. 


\title{
SUMMARY
}

\author{
Author: Luciana Veiga Barbosa \\ Adviser: Profa. Dra. Maria Lúcia Carneiro Vieira
}

Brazil is considered the world's greatest passionfruit producer, with approximately 33,000 ha of area. Howerver, the yield is low (8 to 10 t/ha), which is mainly due to phytosanitary problems. Breeding programs, via sexual hybridization, aiming at introgressing resistance genes from wild species, have been conducted, but with modest results. This is caused by selfincompatibility and cross-incompatibility of the species from Passiflora genus, which impairs the utilization of sexual hybridization. An alternative to supars this barrier is somatic hybridization, via protoplast fusion. Following a research line developed at Genetic Departament (ESALQ/USP - Piracicaba (SP), this thesis work proposes to present studies on vegetative and reprodutive development of somatic hybrids between the commercial species P. edulis Sims f. flavicarpa Deg. (E) and wild species carrying disease resistance genes, $P$. alata $(\mathrm{AL}), P$. cincinnata $(\mathrm{C}), P$. giberti $(\mathrm{G})$ and $P$. amethystina $(\mathrm{Am})$, all with $2 \mathrm{n}=2 \mathrm{x}=18$ chromosomes. Cytological anayses confirmed the hybrid nature of $(E+A m)$ and $(E+C)$, as hybrids plants from these combinations showed $2 n=4 x=36$ chromosomes. Meiotic alterations with presence of laggard chromosomes and chromatids, early segregating chromosome and anaphase bridges were observed. The hybrids $(E+A m)$ showed univalent, bivalent and quadrivalent kinds of configurations, showing the occurrence of crossing-over between homoeologous chromosome. All hybrids had high polen viability values, up to $70 \%$. Somatic hybrids $(E+C)$ 
showed equally meiotic irregularities and univalents or quadrivalents configuration, also indicating occurence of homoelogous pairing. However, around $70 \%$ of the cells showed 18 bivalents, which explains the high polen viability values. Somatic hybrids $(E+A l)$ and $(E+G)$ showed $2 n=2 x=18$ chromosomes, there were phenotipically similar to wild type parents and presented regular meiosis with nine bivalents formation and high polen viability. In this case, commercial parent chromosome elimination has likely occurred. Poliploid effect on lower epidermis cells of $(E+A m)$ and $(E+C)$ hybrids plants was studied. As the ploidy level increased in the plants, a greater surface area and smaller stomata number were observed. 


\section{1 - INTRODUÇÃO}

A cultura do maracujazeiro possui inegável potencial sócioeconômico para o Brasil, hoje considerado o maior produtor mundial, com uma área plantada de aproximadamente 33.000 ha (BGE, 1993). Em 1994, o Brasil ganhou destaque com uma produção de $380.109 \mathrm{t}$ (FNP - Agrianual, 1998), sendo esse crescimento crescente resultado do impulso gerado pela agroindústria de suco e, principalmente, pela crescente demanda no mercado de fruta 'in natura' (Meleti et al., 1992).

A produção brasileira está distribuída entre as regiões Norte $(36,74$ $\%)$, Nordeste (37,22 \%), Sudeste (23,46\%), Sul (1,18 \%) e Centro-Oeste $(1,40$ \%). Destas regiões, o Estado do Pará é o principal produtor, com uma produção superior a $138.091 \mathrm{t}$, correspondendo a $36,32 \%$ do total produzido no país, seguido de São Paulo, Sergipe, Bahia, Ceará e, Minas Gerais (FNP - Agrianual, 1998), sendo os plantios comerciais, constituídos basicamente da espécie $P$. edulis Sims. f. flavicarpa Deg.

A expansão da cultura vem sendo limitada pela falta de recursos técnico-científicos para superar os problemas, particularmente os de ordem fitossanitária. Em vista disso, é considerada uma cultura de alto risco, com elevado custo de produção. Desta forma, torna-se evidente a necessidade de se investigarem métodos alternativos de controle de doenças.

Dentre as principais doenças, a morte súbita das plantas, doença que ocorre no sistema radicular, de etiologia desconhecida e que provoca a morte da planta em qualquer fase do seu desenvolvimento (Papa, 1990), e a bacteriose, 
provocada por Xanthomonas sp. pv. passiflorae, constituem-se nos principais problemas básicos da cultura, visto que o controle preventivo é oneroso (Dias \& Takatsu, 1990).

A resistência varietal constituir-se-ia na melhor alternativa para o controle de doenças. Programas de melhoramento genético do maracujazeiro têm sido conduzidos no Brasil visando a seleção de variedades mais produtivas e resistentes a pragas e doenças, por meio da hibridação entre a espécie cultivada e espécies selvagens. No entanto, existem dificuldades metodológicas uma vez que os maracujazeiros são autoincompatíveis e, dentro de uma mesma espécie, as plantas apresentam incompatibilidade cruzada limitando o uso de determinados métodos de melhoramento, como a hibridação interespecífica e o uso do retrocruzamento (Bruckner, 1994). Dessa forma, a utilização da hibridação interespecífica é dificultada, havendo a necessidade de alternativas para contornar as barreiras de incompatibilidade.

Métodos de biotecnologia vegetal têm sido indicados na literatura para complementar certos programas de melhoramento genético. Assim, no caso específico do maracujazeiro, a hibridação somática, via fusão de protoplastos, representa uma alternativa de transferência de genes de resistência a doenças, presentes em espécies selvagens, para a espécie cultivada.

Híbridos somáticos envolvendo a espécie cultivada e espécies selvagens de Passiflora, portadoras de genes de interesse, foram produzidos no Departamento de Genética da ESALQ/USP (Dornelas et al., 1995) e, após aclimatação em casa de vegetação, foram levados ao campo experimental onde se desenvolveram e apresentaram florescimento abundante. Informações sobre os arranjos cromossômicos e os mecanismos envolvidos no processo de recombinação são de grande importância para o processo de seleção e obtenção das progênies híbridas, permitindo um planejamento mais eficiente na condução dos programas de melhoramento genético. 
Dando continuidade à essa linha de pesquisa desenvolvida no Departamento de Genética (ESALQ/USP - Piracicaba/SP), esta tese se propôs a:

- Avaliar o comportamento reprodutivo das espécies cultivadas $P$. edulis Sims f. flavicarpa Deg., $P$. alata e das espécies selvagens $P$. giberti, $P$. amethystina e $P$. cincinnata, todas apresentando $2 \mathrm{n}=2 \mathrm{x}=18$ cromossomos e, dos híbridos somáticos obtidos via fusão química de protoplastos $(2 n=4 x=36)$, entre $P$. edulis Sims. f. flavicarpa Deg. e as demais espécies, visando inferir sobre a possibilidade da utilização desses híbridos em programas de melhoramento;

- Estimar os valores médios de viabilidade do grão de pólen das espécies e híbridos somáticos correspondentes, correlacionando-os com as irregularidades meióticas observadas;

- Avaliar o efeito da poliploidia nas células da epiderme foliar dos híbridos somáticos. 


\section{2 - REVISÃO DE LITERATURA}

\section{1 - Botânica}

O maracujazeiro pertence a ordem Passiflorales que possui três famílias, sendo a de maior interesse comercial a Passifloraceae, que compreende 18 gêneros que incluem cerca de 630 espécies, com distribuição principalmente nos trópicos da América, Ásia e África (Vanderplanck, 1996). Desses gêneros, destaca-se o Passiflora, com cerca de 150 espécies nativas do Brasil, dessas quais, mais de 60 produzem frutos que podem ser aproveitados direta ou indiretamente na alimentação (Teixeira, 1994).

O gênero Passiflora originou-se nas florestas da América do Sul tropical, na região da Amazônia brasileira e, possivelmente, no Paraguai e Argentina (Winks et al., 1988). Esse gênero compreende trepadeiras herbáceas ou lenhosas, podendo apresentar-se como ervas e arbustos de hastes cilíndricas ou quadrangulares, angulosas, suberificadas, glabras ou pilosas. Seus representantes apresentam as características da familia e diferem dos outros gêneros pela presença de cinco estames, cinco pétalas e cinco sépalas, pelo ginandróforo ereto com estames de extremidades livres e três estigmas.

Apesar do elevado número de espécies que formam o gênero Passiflora, apenas algumas apresentam importância econômica, devido à qualidade de seus frutos ou à sua adaptabilidade como trepadeiras ornamentais ou, ainda, pelas suas propriedades medicinais (Teixeira, 1994). 


\section{2 - Importância econômica}

O Brasil é o primeiro produtor mundial de maracujá (Ruggiero, 1991). Ao nível mundial, desde 1977 , o produto nacional vem despertando o interesse dos mercados internacionais, fazendo da cultura uma boa alternativa para um aumento de receita dos produtores e na obtenção de divisas para o país, devida à exportação de suco (Projeto Maracujá, 1977).

No Brasil, a cultura tomou grande impulso a partir de 1970, quando ela se expandiu principalmente na região Norte e Nordeste do país, para atender a demanda das indústrias de suco concentrado para a exportação (Chagas, 1991).

Vários Estados cultivam o maracujazeiro, com destaque para o Pará, Bahia, Sergipe, Rio de Janeiro, Ceará e Minas Gerais, apresentando uma produtividade média em torno de 8 a 10 tha, a qual pode ser considerada baixa, quando comparada à do Havaí que apresenta, em média, um rendimento de 50 t/ha. Em São Paulo, na região de Presidente Prudente, observa-se uma excelente produtividade média de 40 a 50 t/ha, sendo os plantios comerciais dominados pela espécie $P$. edulis Sims. f. flavicarpa Deg. ou maracujá amarelo (Oliveira \& Ferreira, 1991).

As exportações brasileiras, tanto de suco integral quanto concentrado, vêm apresentando um crescimento significativo, convertendo o Brasil no maior exportador. Por exemplo, no ano de 1992, o volume de maracujá amarelo comercializado no Brasil pelo CEAGESP foi de $15.172 \mathrm{t}$ e, no ano de 1996, esse volume duplicou, alcançando um patamar de 30.069 t, um aumento significativo de cerca de $100 \%$. No entanto, tem-se observado, grandes oscilações nas quantidades e preços do produto, devido à competição de outros produtos, levando a um desestímulo dos produtores; políticas de mercado, fatores não claramente definidos, que provocam drásticas reduções 
no preço e, principalmente, problemas de ordem fitossanitários, o que torna a cultura migratória (FRUPEX, 1996).

\section{3 - Principais problemas da cultura}

Vários são os problemas que surgiram com o avanço da cultura, e, entre eles, os de ordem fitossanitária, principalmente as doenças causadas por fungos, bactérias e vírus. No caso do maracujazeiro, o controle químico tem sido uma questão delicada (Souza \& Meletti, 1997).

Das doenças que ocorrem no maracujazeiro, duas se destacam. A morte prematura das plantas, doença que ocorre no sistema radicular, de etiologia desconhecida, se caracteriza ao nível de campo, por um ligeiro amarelecimento e uma murcha brusca das plantas. A região do colo destas plantas apresenta-se necrosada e, parte do sistema radicular apodrecido, ocasionando sua morte (Figura 1). Dias \& Takatsu (1990) relatam que esta doença, associada à presença de patógenos da parte aérea, é uma moléstia que vem afetando as plantações de maracujá amarelo desde a região Nordeste até a Sudeste do país, podendo reduzir a idade útil de produção da planta para menos de dois anos. No Brasil, a primeira constatação dessa doença foi feita no Estado de São Paulo, em Jaboticabal, onde causou danos severos à cultura, ocorrendo em alguns casos perdas de até 100\% na produção (Papa, 1990).

Em locais de plantio recente de maracujá amarelo, a doença sempre aparece na época quente e úmida, época em que a planta está em franco desenvolvimento e frutificação. A utilização de maracujazeiro amarelo enxertado sobre porta-enxerto resistente, a curto prazo, parece ser uma medida mais eficiente para o convívio com a morte prematura das plantas (Greeck \& Reijkenberg, 1991; Ruggiero, 1991). No entanto, o uso de plantas enxertadas requer maiores cuidados quanto ao controle de doenças da parte aérea, pois essas apresentam menor vigor, menor produção e menor capacidade de 
recuperação após a desfolha devido a pragas e doenças além do maior custo, período de tempo necessário para a obtenção da muda e, queda de cerca de 30\% na produção (Papa, 1990) (EMBRAPA - Reunião Técnica, 1998).

Outra doença de importância econômica é a bacteriose provocada por Xanthomonas campestris pv. Passiflorae, caracterizada por um lento e progressivo amarelecimento das folhas e dos ramos ponteiros, evoluindo para uma intensa desfolha e definhamento da planta após a primeira safra (Figura 1B) (Barbosa, 1995). Dias \& Takatsu (1990) comentam que essa bacteriose desempenha papel fundamental na morte precoce do maracujazeiro amarelo. Souza \& Meletti (1997) relatam que esta é uma das principais doenças da cultura, principalmente se associada à antracnose. Também ocorre em condições de elevada temperatura e umidade e, em plantas com distúrbios nutricionais. Medidas disponíveis para o controle da bacteriose, como a produção de mudas sadias, poda de limpeza, uso de quebra-ventos e aplicação de bactericidas não têm apresentado resultados satisfatórios no controle da doença (EMBRAPA - Reunião Técnica, 1998).

No maracujazeiro, as doenças fúngicas e bacterianas são controladas preventivamente, ou seja, por meio de pulverizações com oxicloreto de cobre, na dose recomendada pelo fabricante, a intervalos quinzenais no período seco do ano e semanais, nos meses quentes e chuvosos.

Ao se considerar que os problemas fitossanitários conduzem à uma redução da vida útil do maracujazeiro, um número maior de pesquisas deve ser desenvolvido para um melhor conhecimento do seu agente causal e para a adoção de medidas que possam minimizar a ocorrência de doenças (Teixeira, 1994). 

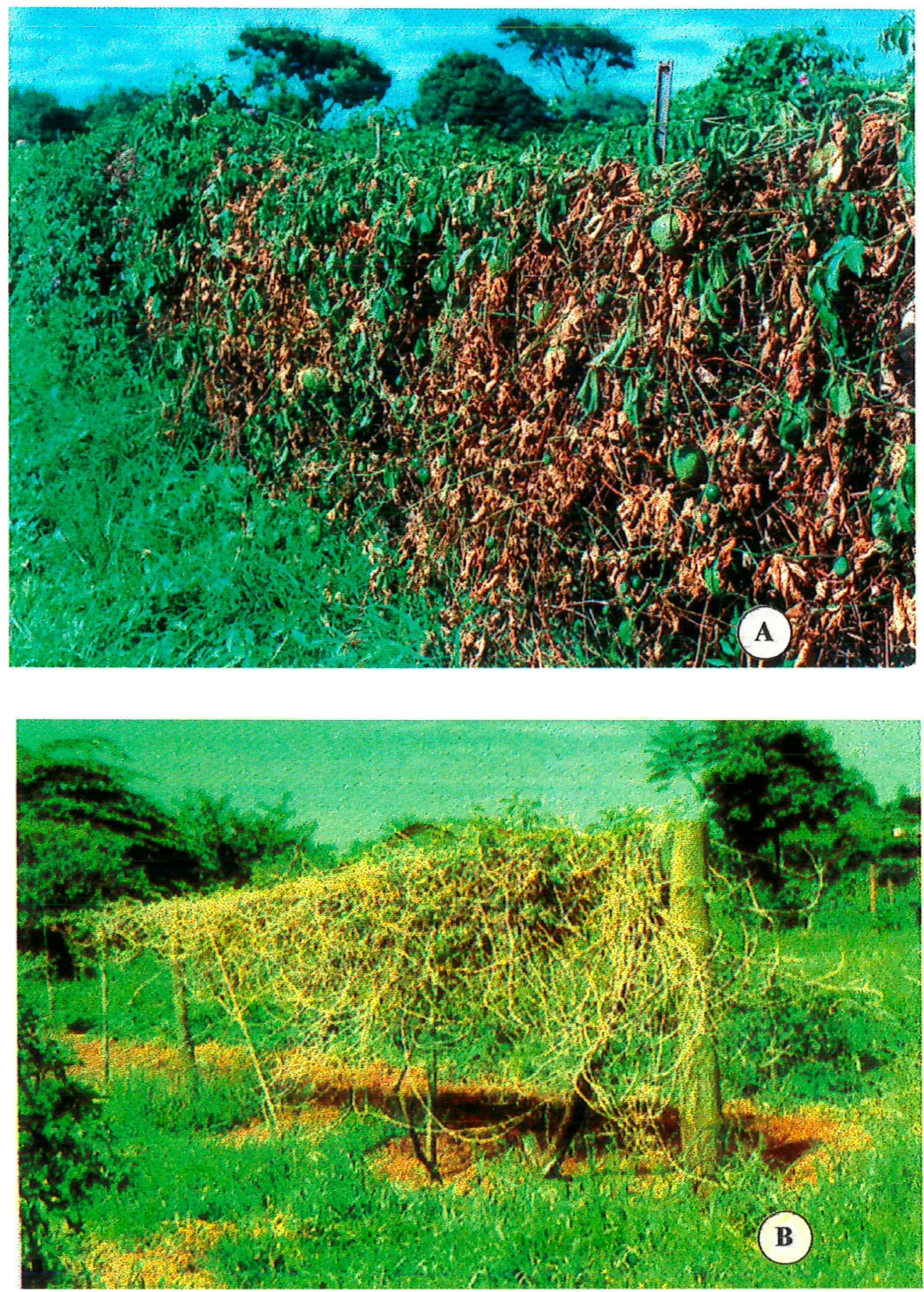

Figura 1 - Incidência da morte prematura das plantas (A) e da bacteriose causada por Xanthomonas campestris pv. passiflorae (B), em P. edulis Sims. $\mathrm{f}$. flonicarpa Deg. 


\section{4 - Melhoramento genético}

Sabe-se que, a expansão de qualquer monocultura leva a eliminação das espécies selvagens. Desta forma, muitos genótipos que poderiam ser utilizados, por exemplo, no melhoramento de uma determinada espécie desaparecem, uma vez que a tendência atual da agricultura é a eliminação de grande parte da diversidade, pela utilização de poucas variedades melhoradas e uniformes. Na tentativa de se evitar a redução da variabilidade genética, a coleta de germoplasma é prioritária para se continuar tendo sucesso em programas de melhoramento genético.

O gênero Passiflora é essencialmente americano, sendo o Brasil o principal centro de diversidade genética. Apesar dessa variabilidade, a preocupação em mantê-la não tem sido expressiva, sendo modesto o número de materiais mantido em coleções (Souza \& Meletti, 1997). Além disso, o aproveitamento e utilização dessa diversidade no país são limitados, já que a manutenção dos genótipos em coleções é laboriosa, o que dificulta o trabalho dos melhoristas (EMBRAPA - Reunião Técnica, 1998).

A flor do maracujá amarelo é perfeita, porém auto-estéril, sendo assim necessária a ocorrência de polinização cruzada entre plantas diferentes. As espécies apresentam variabilidade para características de fruto e morfologia da planta, coloração de folhas e frutos, caules e gavinhas e, principalmente, na susceptibilidade a patógenos (Oliveira, 1980; Oliveira et al., 1987). Muitas espécies de Passiflora apresentam igualmente características agronômicas e nutricionais que podem ser exploradas diretamente ou introduzidas por hibridação (Ruggiero, 1987) mas, apesar disso, a exploração dessas espécies tem sido praticamente nula.

O maracujazeiro é uma espécie alógama de cultivo recente, com ampla variabilidade genética a ser explorada (Oliveira et al. 1987) e, a 
ocorrência do mecanismo de incompatibilidade, tem também limitado o uso certos métodos de melhoramento genético (Bruckner, 1994).

O melhoramento genético de plantas alógamas se dá, essencialmente, pela obtenção de populações melhoradas a partir do aumento das frequências de genes favoráveis nessas populações ou pela utilização da heterose em híbridos.

O aumento da freqüência gênica é conseguido via seleção massal, que é mais efetiva para caracteres qualitativos de alta herdabilidade e seleção em testes de progênies, que se baseia na avaliação das progênies, levando em consideração a capacidade do indivíduo em produzir descendentes superiores do que propriamente o seu valor individual (Pinto, 1995).

A heterose por sua vez, é aproveitada em híbridos ou variedades sintéticas (Allard, 1971). Os híbridos são constituídos a partir de linhagens homozigóticas, variedades de polinização livre, clones ou outras populações divergentes. Híbridos heteróticos se caracterizam por uma maior uniformidade, estabilidade e homeostase genética (menor interação genótipo $\mathrm{x}$ ambiente). Além dessas características, pode-se combinar em um único indivíduo as características presentes nos parentais, obtendo genótipos superiores em espaço de tempo relativamente curto (Pinto, 1995).

As variedades sintéticas são obtidas por hibridação entre genótipos selecionados, que podem ser linhagens, clones ou populações melhoradas, sendo incluídos apenas genótipos que possuem maior capacidade de combinação. Essas variedades possibilitam a utilização controlada da heterose em grau apreciável (Allard, 1971).

Pesquisas têm sido conduzidas em maracujá visando um aumento de produtividade e resistência a doenças, através da introdução de plantas ou por obtenção de populações melhoradas a partir do aumento das freqüências de genes favoráveis obtidos através da seleção massal e com a seleção em testes de progênies (Bruckner, 1994). Hibridações interespecíficas também têm 
sido utilizadas, no entanto estas apresentam resultados modestos (Oliveira, 1980; Oliveira et al., 1987 e Oliveira \& Ferreira, 1991). A falta de uma variedade homogênea e produtiva, tolerante às principais moléstias que afetam a cultura, tem dificultado o aumento na qualidade e produtividade dos pomares comerciais. Para desenvolver essa variedade, é preciso manter, caracterizar e utilizar convenientemente o germoplasma disponível, em programas de melhoramento bem conduzidos.

A avaliação de plantas individuais de maracujazeiros para produtividade é muito difícil; devido ao modo de condução, a planta requer poda de ramos constantemente a fim de manter sua individualidade, o que contribui para a não identificação dos genótipos mais favoráveis. Outro fator considerado é a vida útil anual e a performance das plantas durante o cultivo. Em termos de melhoramento genético, os produtores, inconscientemente já praticam a seleção individual das plantas, pois na implantação de suas lavouras coletam sementes de boa procedência, plantas produtivas, sadias, frutos com bom tamanho, bom rendimento em suco, suco de coloração amarelo canário, alta acidez e teor de sólidos solúveis.

São escassos os trabalhos de melhoramento do maracujazeiro realizados tanto no Brasil como nos demais países produtores, onde ainda não existem variedades comercias definidas (Bruckner, 1994). Destacam-se por exemplo, os trabalhos desenvolvidos pelo Centro Nacional de Pesquisa em Mandioca e Fruticultura (EMBRAPA/CNPMF - Cruz das Almas, BA), Instituto Agronômico de Campinas (IAC - Campinas, SP), Instituto de Pesquisa Agropecuária do Paraná (IAPAR - Londrina, PR), Escola Superior de Agricultura Luiz de Queiroz (ESALQ/USP - Piracicaba, SP), Faculdade de Ciências Agrárias e Veterinárias de Jaboticabal (FCAVJ/UNESP - Jaboticabal, SP), Universidade Estadual do Sudoeste da Bahia (Vitória da Conquista, BA), entre outras. No entanto, esses ainda apresentam resultados modestos, principalmente no que diz respeito à avaliação individual das plantas 
(EMBRAPA - Reunião Técnica, 1998). Feitas tais considerações, a seguir serão resumidos alguns dos trabalhos desenvolvidos na cultura, ao nível nacional e internacional.

Objetivando estudar o funcionamento e herança da autoincompatibilidade presente em plantas de maracujazeiro, Bruckner (1994) avaliou plantas de $P$. edulis Sims. f. flavicarpa Deg. e P. edulis Sims. Progênies foram obtidas e analisadas em sistema de autofecundações, cruzamentos recíprocos em esquema de dialelo e em retrocruzamentos com relação à percentagem de pegamento e número de sementes por fruto. Os resultados indicaram que a auto-incompatibilidade no maracujazeiro é do tipo esporofitica, de herança monofatorial e que a relação de dominância entre os alelos responsáveis pela incompatibilidade é aparentemente a mesma no estigma e no pólen. O mesmo autor comenta que a ocorrência da incompatibilidade em espécies de maracujazeiro tem contribuído para o insucesso nos programas de melhoramento genético, via hibridação sexual.

Oliveira et al. (1983 e 1987), cultivando espécies de maracujazeiros em local com histórico da morte prematura de plantas, verificaram que $P$. giberti N.E. Brown, P. alata Ait e Passiflora sp. (maracujá de cobra) apresentaram resistência à doença. Já em $P$. edulis Sims f. flavicarpa Deg., as formas cultivadas e as formas de diferentes origens foram susceptíveis, o que levou os autores a concluir que nesta espécie não existem fontes de resistência.

No sentido de transferir os genes de resistência à morte prematura presente na espécie $P$. giberti, para a espécie cultivada $P$. edulis Sims. f. flavicarpa Deg., foram obtidos híbridos interespecíficos $F_{1}$, no entanto, além de apresentarem características morfológicas indesejáveis de $P$. giberti, foram altamente susceptíveis à doença, sugerindo que a resistência é condicionada por genes recessivos. Quando comparados aos progenitores, observou-se acentuada depressão dos mesmos, apresentando uma maior 
susceptibilidade também às doenças da parte aérea, fertilidade baixa e variável (Ruggiero, 1991).

Knight Jr \& Winters (1962), estudando a polinização e frutificação em cruzamentos recíprocos no maracujazeiro, observaram a ocorrência da incompatibilidade em vários cruzamentos, porém em diferentes graus. Em parte desses cruzamentos, o resultado foi o mesmo para plantas usadas como progenitor feminino ou masculino, mas em quatro cruzamentos recíprocos, foram encontradas diferenças que foram atribuídas a uma possível esterilidade masculina. Além do problema da auto-incompatibilidade, o maracujá amarelo apresenta incompatibilidade cruzada, isto é, na presença de várias plantas, pode não ocorrer uma boa frutificação. No entanto, em trabalhos de autofecundações com flores dessa espécie, foi observado uma taxa de $10 \%$ de pegamento.

\section{5 - Melhoramento assistido por biotecnologia}

A contribuição dos recursos genéticos no melhoramento de muitas espécies de plantas é indiscutível. Através da hibridação sexual, muitos genes de interesse presentes em espécies selvagens têm sido incorporados em espécies de interesse econômico. Por exemplo, no caso do tomateiro, algodão e a batata, se não fossem os genes presentes nas espécies selvagens, com certeza tais culturas não estariam sendo cultivadas em grande escala (Harlan, 1981; Vieira, 1997). No entanto, problemas relacionados à ocorrência de incompatibilidade em algumas espécies, tem impossibilitado o sucesso da hibridação sexual, uma vez que este depende das relações filogenéticas entre as espécies envolvidas no cruzamento. Uma alternativa para contornar esse problema é a técnica de resgate de embriões. Essa técnica se baseia na excisão de embriões imaturos e desenvolvimento 'in vitro'. Em batata essa técnica tem sido muito utilizada (Vieira, 1997). 
Métodos biotecnológicos, como a hibridação somática através da fusão de protoplastos, tem se constituído em uma alternativa para contornar barreiras de cruzamentos entre espécies sexualmente incompatíveis e para ampliar a variabilidade genética em plantas superiores (Lefrançois et al., 1993).

O termo protoplasto é normalmente usado para descrever células livres de parede celular. A ausência da parede celular faz dos protoplastos um sistema útil para uma variedade de manipulações experimentais que não são possíveis com células intactas (Fungaro \& Vieira, 1989). A fusão de protoplastos resulta em heterocários que contém o núcleo e organelas de ambos os parentais. Os núcleos geralmente se fundem, no entanto, as organelas passam por uma seleção. A presença de dois DNAs organelares, geneticamente diferentes mas, homólogos, pode resultar em recombinação do material genético. Todavia, isto pode ocorrer somente quando as organelas se fundem, permitindo a interação física das moléculas de DNA dentro das organelas (Wolters et al., 1994).

Os produtos gerados a partir da fusão de protoplastos podem ser classificados em três categorias, sendo esta caracterização dependente do objetivo e dos fenômenos biológicos que ocorrem durante o processo de fusão até a regeneração de plantas inteiras (Fungaro \& Vieira, 1989):

- Híbridos somáticos simétricos: quando o produto final apresenta núcleo e citoplasma híbridos;

- Híbridos somáticos assimétricos: quando o núcleo da espécie selvagem é fragmentado antes da fusão e;

- Cíbridos: quando há obtenção de çitoplasmas híbridos, a fim de combinar organelas de espécies onde estas são herdadas do progenitor materno ou, para obter recombinação entre organelas de espécies diferentes. 
Além disso, a hibridação somática tem sido igualmente utilizada para mapear genes e em estudos de filogenia das espécies submetidas ao processo de fusão (Gilissen et al., 1992).

Os protoplastos de plantas têm sido estudados desde a década de 60 , iniciando-se com os trabalhos de Cocking na Universidade de Nottingham, Inglaterra (Cocking, 1960). Entretanto, somente em 1972 foi relatada a regeneração de um híbrido vegetal (Carlson et al., 1972). Desde então, 60 espécies de plantas foram regeneradas (Binding et al., 1982) e, atualmente, algumas centenas de espécies e a maioria das plantas de interesse agronômico podem ser regeneradas a partir de protoplastos, inclusive algumas leguminosas e gramíneas, consideradas recalcitrantes à cultura "in vitro" (Dornelas, 1995).

Embora exista um grande número de trabalhos envolvendo a hibridação somática por meio da fusão de protoplastos (Glimelius et al., 1991; Knight Jr., 1991; Louzada et al., 1992; Taguchi et al., 1993; Fahleson et al., 1994; Parokonny et al., 1994; Wolters et al., 1994a; Yamagishi et al., 1994; Kisaka \& Kameya, 1994; Otoni et al., 1995), pouco se sabe a respeito do comportamento vegetativo e reprodutivo dos híbridos produzidos.

\section{6 - Citogenética de híbridos somáticos}

As estratégias utilizadas para a introgressão de genes em plantas dependem da incorporação estável desses genes no genoma hospedeiro, quer por hibridação sexual, fusão de células somáticas ou por transformação de plantas, via tecnologia do DNA recombinante.

A hibridação somática permite a incorporação em um mesmo organismo de cromossomos ou segmentos cromossômicos de espécies distintas porém, possui desvantagens, como a expressão de genes indesejáveis (particularmente aqueles presentes em espécies selvagens) bem como interações entre genomas parentais o que pode levar à ocorrência de meiose 
anormal nos híbridos ou eliminação unilateral dos cromossomos. No entanto, pequenos segmentos de DNA de uma espécie, incorporados no genoma da outra espécie, por translocação cromossômica, por exemplo, podem levar à introgressão estável de genes no genoma hospedeiro (Parokonny et al., 1994).

A ocorrência de recombinação meiótica entre os cromossomos dos dois genomas envolvidos no processo de fusão é essencial para a introgressão gênica. Ao contrário da hibridação sexual, os parentais do híbrido somático contribuem com lotes diplóides de cromossomos. Consequentemente, se nenhum pareamento ocorrer entre os cromossomos homeólogos, os híbridos somáticos tendem a mostrar um comportamento semelhante à um diplóide normal e somente serão observados bivalentes durante o processo meiótico. Esses híbridos podem se apresentar estáveis e férteis, porém a introgressão só será possível por uma substituição cromossômica. No entanto, se ocorrer pareamento entre os cromossomos homeólogos essa estabilidade e fertilidade tendem a ser reduzidas devido à formação de multivalentes; porém a introgressão gênica de uma espécie para outra pode ser possível (Barbosa \& Vieira, 1997).

\subsection{1 - Mitose em híbridos somáticos}

Nos experimentos de fusão de protoplastos, tem-se observado que as plantas híbridas regeneradas apresentam número de cromossomos variável, ocorrendo desde plantas totalmente estéreis até plantas totalmente férteis (Lefrançois et al.,1993). A combinação de genomas não-aparentados pode ocasionar a eliminação de cromossomos paternos, impedindo a formação de híbridos. Para espécies relacionadas, geralmente, a eliminação cromossômica é parcial de modo que é possível a introdução de certas características genéticas. 
A eliminação cromossômica é um processo aleatório, o que dificulta o controle do processo. A combinação de genomas não-aparentados pode levar a uma perda total ou parcial dos cromossomos, gerando os cíbridos (indivíduos cujo DNA nuclear é de uma espécie e o DNA citoplasmático é da outra espécie ou de ambas que foram envolvidas no processo de fusão). Essa situação possui vantagens pela possibilidade de combinação de genes citoplasmáticos. Esta eliminação tem sido relatada em algumas espécies. Em brassicas, Sundenberg \& Glimelius (1991) encontraram uma correlação entre a frequência de híbridos com eliminação cromossômica e a divergência genética $(r=0,94)$. Os autores sugerem que o fenômeno pode estar associado à duração do ciclo celular. Enquanto ocorre a síntese de DNA de um dos genomas no núcleo híbrido o outro genoma pode ainda não estar se duplicando. Assim, a segregação cromatídica pode ficar prejudicada, levando à ocorrência de perda cromossômica. Este não-sincronismo do ciclo celular e também do tempo de duração de cada fase da mitose pode ser maior à medida que aumenta a divergência das espécies envolvidas. Além destas observações, os autores concluíram que híbridos somáticos com um mesmo nível de ploidia apresentam menor porcentagem de eliminação cromossômica, quando comparados com aqueles em que as espécies parentais possuem níveis variados de ploidia.

Em híbridos somáticos intra e interespecíficos, híbridos intergenéricos e, algumas vezes, em híbridos entre espécies não relacionadas (híbridos intertribais, intersubfamiliais), ambos os genomas parentais podem ser estáveis, sem uma evidência de eliminação cromossômica (Babiychuk et al., 1992; Kisaka \& Kameya, 1994). Geralmente, em se tratando de espécies distantes, pode ocorrer essa eliminação espontânea de um dos genomas parentais.

Já para híbridos somáticos entre Solanum tuberosum + Nicotiana plumbaginifolia, Gilissen et al. (1992) observaram, pela análise do cariótipo 
dos calos híbridos produzidos após um ano de cultivo, uma tendência à eliminação cromossômica. Os autores comentam que o mecanismo envolvido nessa eliminação espontânea é ainda desconhecido, porém eles sugerem que um ou mais fatores estariam diretamente envolvidos. Interações dos genomas nucleares e citoplasmáticos relacionadas com distâncias filogenéticas, tipo de explante, origem dos tecidos, estado metabólico, volume celular, duração do ciclo celular e nível de ploidia dos protoplastos parentais e, complementando, distribuição dos genomas parentais dentro do núcleo híbrido e diferentes padrões de segregação cromatídica entre os cromossomos parentais durante a anáfase, seriam os principais mecanismos envolvidos nessa eliminação.

Willians et al. (1990) estudando híbridos somáticos entre as espécies Solanum brevidens $+S$. tuberosum, puderam observar que, em se tratando de cultura de tecidos, a eliminação cromossômica pode ocorrer aleatoriamente enquanto, em se tratando de híbridos somáticos, esta perda pode ser preferencial para certos cromossomos ou grupo de cromossomos parentais. Evidências citológicas sugerem ainda que aberrações estruturais, como presença de translocações heterozigotas, envolvendo vários cromossomos, podem resultar em uma alta porcentagem de gametas aneuplóides, sementes inviáveis e progênies estéreis.

Wolters et al. (1994) estudando as anormalidades mitóticas em híbridos somáticos entre Lycopersicon esculentum + Solanum tuberosum puderam observar uma alta porcentagem de aneuplóides, sendo que estas anormalidades provavelmente ocorreram durante a fase de calo. Essa aneuploidia pode ter ocorrido devido à uma não-disjunção cromossômica, ocasionando cromossomos atrasados na anáfase e pontes anafásicas (Sunderland, 1977). Esta eliminação cromossômica tem sido observada em outros estudos, os quais sugerem que a instabilidade mitótica assim como a segregação cromossômica desigual ocorrem durante a fase de propagação vegetativa, porém não são todos os cromossomos que são eliminados 
(Lefrançois et al., 1993). Em híbridos somáticos entre Solanum tuberosum $+S$. phureja, Pijnacker et al. (1987, 1989), puderam observar uma eliminação preferencial dos cromossomos de $S$. phureja.

Usando marcadores do tipo dos RFLPs, Wolters et al. (1994) observaram que os cromossomos dos híbridos somáticos entre tomate e batata foram eliminados aleatoriamente. Pela técnica da hibridação 'in situ' foi identificado que uma planta híbrida apresentava um cromossomo recombinante, constituído de um braço cromossômico de tomate e outro de batata. Este cromossomo recombinante é provavelmente produto de uma translocação Robertsoniana, resultante de quebra na região centromérica e fusão, envolvendo os cromossomos da batata e do tomate.

Em híbridos somáticos assimétricos, pode também ocorrer eliminação de cromossomos do parental cultivado. Essa variação no número de cromossomos está relacionada com aberrações citogenéticas como a aneuploidia e rearranjos cromossômicos. Isso pode levar a uma completa esterilidade da planta, o que dificulta os programas de melhoramento genético, uma vez que há a necessidade de realizar vários retrocruzamentos com o parental recorrente visando introgredir somente o gene de interesse (Wijbrandi et al., 1990). Cabe ressaltar que, em termos práticos, em um programa de melhoramento genético cujo objetivo é a transferência parcial do genoma silvestre é necessário um maior conhecimento dos fatores que induzem à essa eliminação cromossômica e dos mecanismos envolvidos nessa transferência, bem como o modo de expressão dos genes introgredidos (Gilissen et al., 1992). 


\subsection{2 - Meiose e viabilidade do grão de pólen em híbridos somáticos}

Vários são os estudos envolvendo a produção de híbridos somáticos tanto simétricos (nesse caso, o núcleo e o citoplasma do híbrido são constituídos de DNA de ambos os parentais envolvidos no processo de fusão) como assimétricos porém, poucos são os estudos encontrados na literatura sobre o seu comportamento meiótico.

O sucesso da técnica da hibridação somática depende da ocorrência de recombinação entre os cromossomos homeólogos e, consequentemente, da presença de irregularidades meióticas que reduz a viabilidade dos gametas (Jong et al., 1993; Wolters et al., 1994a; Barbosa \& Vieira, 1997). Se as duas espécies utilizadas no processo de fusão são relacionadas, é esperado que o híbrido somático contenha a soma dos complementos cromossômicos parentais. No entanto, existem vários relatos na literatura em que se observa uma alta frequência de híbridos somáticos aneuplóides (Wolters et al., 1994a).

Em se tratando de melhoramento genético, a introgressão de genes de uma espécie para outra de uma forma estável é um fator primordial, porém a fertilidade do híbrido somático é mais importante ainda, isto garante a possibilidade de se obter progênies, preferencialmente via retrocruzamento com a espécie recorrente (Wolters et al., 1994a). Dessa forma, há a possibilidade de ocorrer recombinação meiótica entre os cromossomos homeólogos. Neste caso, o pareamento e recombinação cromossômica estão diretamente relacionados às irregularidades meióticas e, consequentemente, à viabilidade parcial dos gametas (Jong et al, 1993).

Quando se obtém híbridos somáticos férteis (seja na parte feminina ou masculina), a ocorrência de recombinação homeóloga entre os cromossomos parentais é vantajosa, pois possibilita a introgressão gênica. Esta 
recombinação homeóloga é normalmente observada durante a diacinese ou metáfase I da meiose pelas configurações de multivalentes, ou por análises em microscopia eletrônica, observando a formação do complexo sinaptonêmico.

Os híbridos somáticos apresentam uma grande variação em termos de fertilidade, mostrando-se desde férteis até totalmente estéreis. Muitos dos híbridos somáticos obtidos entre espécies sexualmente incompatíveis descritos na literatura, têm apresentado baixa fertilidade ou até completa esterilidade, o que limita sua utilização nos programas de melhoramento genético (Taguchi et al., 1993). Lefrançois et al. (1993), estudando híbridos somáticos do gênero Lycopersicon relataram que os produtos de fusão entre as espécies $L$. pennellii $+L$. peruvianum apresentaram fertilidade em torno de $3 \%$. No entanto, quando se considerou híbridos somáticos entre L. esculentum + L. peruvianum, estes foram férteis, o que abre novas perspectivas para o melhoramento genético do tomateiro, uma vez que L. peruvianum (que é fonte de resistência a várias doenças) apresenta incompatibilidade bilateral com a espécie cultivada o que impossibilita o uso da metodologia de hibridação sexual. Em outras combinações híbridas, foi observada a ocorrência de uma meiose anormal, com a presença de cromossomos atrasados e de micronúcleos na telófase II.

Em híbridos somáticos entre Brassica oleracea + B. campestris, foram observados, em média, valores de $88 \%$ de viabilidade do grão de pólen, indicando um comportamento meiótico estável das plantas híbridas. Estes resultados indicam que tais híbridos são promissores em termos de melhoramento dada a possibilidade de se obter progênies híbridas (Yamagishi et al., 1994). Para os híbridos obtidos por fusão de protoplastos entre $B$. alboglabra e $B$. campestris, foi observado que todas as plantas apresentavam grãos de pólen viáveis, mesmo ocorrendo uma meiose anormal. Tais híbridos apresentaram cromossomos atrasados e pontes anafásicas. Essas aberrações foram atribuídas às falhas de pareamento cromossômico durante a meiose 
(Olin-Fatih et al., 1996). Nos híbridos somáticos, Brassica juncea + Diplotaxis harra, pode-se observar a formação de tetravalentes e um hexavalente na diacinese e metáfase I. Isto indica que ocorreu um pareamento homeólogo entre os cromossomos destas duas espécies, via crossing-over, sugerindo novos rearranjos cromossômicos. Além dessas configurações, ocorreu uma distribuição irregular dos cromossomos na anáfase I e metáfase II o que ocasionou uma completa esterilidade do grão de pólen (Begum et al., 1995).

Wolters et al. (1994), estudando anormalidades meióticas dos híbridos somáticos Lycopersicon esculentum + Solanum tuberosum, detectaram a presença de univalentes, bivalentes e tetravalentes e, em alguns casos, trivalentes. Outras irregularidades meióticas também foram encontradas, como a presença de pontes cromossômicas e cromossomos atrasados. Os autores sugerem ter havido recombinação homeóloga entre os cromossomos das duas espécies, pela presença de multivalentes, o que foi posteriormente confirmado pela de hibrização 'in situ'. No entanto, os híbridos apresentaramse estéreis, tanto na parte feminina quanto na masculina da flor, não sendo possível se obter progênies.

Ao contrário dessas observações, Jacobsen et al. (1992) puderam visualizar em híbridos somáticos entre o tomate e a batata, a formação de bivalentes e, em alguns casos, univalentes durante o paquíteno e metáfase I o que, em termos de introgressão gênica não é vantajoso, uma vez que não ocorreu recombinação cromossômica.

A tendência de formação de bivalentes observada na meiose de um anfidiplóide natural está diretamente relacionada com o grau de homologia entre os cromossomos parentais, que é consequência do grau de divergência genética entre as espécies (McConnell \& Kamemoto, 1993). Os híbridos somáticos são, na realidade, poliplóides artificiais: numa situação extrema de um híbrido entre espécies não relacionadas, o que se observa é a ocorrência de bivalentes porém, quando a fusão de protoplastos ocorre entre espécies 
relacionadas, há o pareamento e, consequentemente, recombinação refletida pelas configurações de multivalentes. A formação de univalentes geralmente resulta numa baixa fertilidade ou completa esterilidade do grão de pólen (Pagliarini, 1989).

Willians et al. (1993) realizaram uma análise molecular da segregação cromossômica de progênies de híbridos somáticos Solanum brevidens $+S$. tuberosum usando a técnica dos RFLPs. Os autores observaram uma tendência à formação de multivalentes, trivalentes e tetravalentes, bem como à formação de univalentes e bivalentes durante a meiose. Além disso, observaram que ocorreu recombinação em seis dos doze cromossomos analisados. Em híbridos somáticos entre Solanum tuberosum e a espécie selvagem $S$. circaeifolium subsp. circaeifolium Bitter, constatou-se a presença de multivalentes em todas as plantas híbridas, com tendência à formação de trivalentes e tetravalentes. Embora as plantas tenham apresentado uma elevada taxa de florescimento, apresentaram baixa fertilidade ou completa esterilidade (Mattheij et al., 1992).

Em Medicago, Pupilli et al. (1995) observaram que a meiose dos híbridos somáticos ( $M$. sativa + M. coerulea) apresentou algumas anormalidades como formação de univalentes na metáfase I, que resultou na formação de cromossomos atrasados na anáfase I, orientação anormal das fibras do fuso e diferentes tipos de produtos meióticos, como díades, tríades e pêntades. Estas anormalidades também foram observadas nos parentais porém, em baixa proporção quando comparada às dos híbridos.

\section{7 - Hibridação somática no maracujazeiro}

Como dito anteriormente, embora exista uma grande variabilidade no gênero Passiflora, o aproveitamento dessa tem sido praticamente nula, já que existe o mecanismo de incompatibilidade no gênero. 
Isso limita o uso da hibridação interespecífica para o aproveitamento desses genes desejáveis, via retrocruzamentos sucessivos. No caso específico do maracujazeiro, a hibridação somática, via fusão de protoplastos, representa uma alternativa de transferência de genes de espécies selvagens para a espécie cultivada, principalmente pelos avanços recentes sobre o comportamento 'in vitro' das espécies e, principalmente sobre a regeneração de plantas a partir de protoplastos (Domelas et al., 1995).

Existem relatos de hibridação somática entre a espécie comercial de maracujá $P$. edulis Sims. f. flavicarpa Deg. e algumas espécies selvagens objetivando a introgressão de genes para resistência a doenças e resistência ao frio (Domelas et al., 1995 e Otoni et al., 1995).

Em se tratando de hibridação somática em culturas tropicais, Otoni et al. (1995) apresentaram o primeiro relato no gênero Passiflora. Os autores obtiveram híbridos somáticos entre as espécies $P$. edulis Sims. f. flavicarpa Deg. e P. incarnata, citada como tolerante ao frio. Tais híbridos somáticos apresentaram características morfológicas intermediárias às formas parentais.

Na parte de resistência à doenças, Vieira \& Domelas (1996) foram os pioneiros na obtenção de híbridos somáticos entre a espécie cultivada e algumas espécies selvagens de Passiflora portadoras de genes para resistência à doenças, principalmente à morte prematura (presente em $P$. giberti) e à bacteriose provocada pela Xanthomonas campestris pv. Passiflorae (presente em P. cincinnata) (EMBRAPA - Reunião Técnica, 1998).

\section{8 - Efeito da poliploidia nas células da epiderme foliar dos híbridos somáticos}

Uma característica comum dos poliplóides (naturais ou artificiais) é o tamanho aumentado de suas partes vegetativas (chamado efeito 
giga), tornando os poliplóides geralmente bem mais vigorosos do que os diplóides correspondentes (Allard, 1971). O incremento no nível de ploidia de uma planta causa um aumento no tamanho de seus tecidos, devido ao maior volume celular. Desta forma, o número de estômatos observado por campo visual do microscópio ótico bem como o seu tamanho estão correlacionados com o nível de ploidia da planta (Suzuki et al., 1981). Por exemplo, em banana (Musa spp), Simmonds, já em 1948 e Borges (1971) encontraram uma relação proporcional entre o nível de ploidia e o tamanho e densidade dos estômatos. Os mesmos autores concluíram que a análise dos estômatos em poliplóides possui valor diagnóstico na identificação desses materiais. 


\section{3 - MATERIAL E MÉTODOS}

\section{1 - Material vegetal e local de plantio}

A Tabela 1 relaciona os parentais e os híbridos somáticos utilizados no presente trabalho. Os híbridos somáticos foram gerados a partir da fusão química de protoplastos, utilizando o PEG (polietilenoglicol) como substância aglutinante. A identificação dos híbridos somáticos foi realizada pela análise de isoenzimas e de proteínas totais; cerca de 2 a $3 \%$ de calos ou plantas regeneradas apresentaram padrão eletroforético semelhante à mistura física das amostras parentais, conforme descrito por Dornelas (1995).

Esses híbridos foram aclimatados em casa de vegetação (Figura 2A) e transferidos para o campo experimental do Departamento de Genética da ESALQ/USP (Piracicaba - SP), em maio de 1995. Piracicaba (SP) está situada a $22^{\circ} 42^{\prime} 30^{\prime \prime}$ de latitude Sul e $47^{\circ} 38^{\prime} 01^{\prime \prime}$ 'de longitude Oeste. A altitude é de $540 \mathrm{~m}$, precipitação pluviométrica anual média de $1.070,6 \mathrm{~mm}$, temperatura média anual máxima de $37,5^{\circ} \mathrm{C}$ e mínima de $18,0^{\circ} \mathrm{C}$. O solo é classificado como terra roxa estruturada eutrófica.

O espaçamento utilizado foi o de $2,0 \times 3,0 \mathrm{~m}$, com espaldeiramento de um só fio de arame $\mathrm{n}^{\circ} 12$ a $1,80 \mathrm{~m}$ do solo de tal forma a permitir o crescimento vegetativo das plantas (Figura 2B). Os tratos culturais consistiram em capinas manuais e tratamentos fitossanitários, com podas de formação e de manutenção, estando as plantas sujeitas apenas à polinizacão natural, não controlada, realizada por mamangavas do gênero Xylocopa. 
Tabela 1 - Lista das espécies parentais P. edulis Sims. f. flavicarpa (E), P. alata (Al), $P$. cincinnata $(\mathrm{C}), P$. amethystina $(\mathrm{Am})$ e $P$. giberti $(\mathrm{G})$, dos respectivos híbridos somáticos e grau de ploidia na fase de seleção.

\begin{tabular}{|c|c|}
\hline Materiais & Ploidia \\
\hline - Parentais & - \\
\hline - P. edulis Sims. f. flavicarpa (E) & $2 n=2 x=18$ \\
\hline - P. alata (Al) & $2 n=2 x=18$ \\
\hline - P. cincinnata $(\mathrm{C})$ & $2 n=2 x=18$ \\
\hline - P. amethystina (Am) & $2 n=2 x=18$ \\
\hline - P.giberti (G) & $2 n=2 x=18$ \\
\hline - Híbridos somáticos $\left({ }^{*}\right)$ & - \\
\hline$-(\mathrm{E}+\mathrm{Al}) \# 06$ & $2 n=4 x=36$ \\
\hline$-(E+A l) \# 17$ & $2 n=4 x=36$ \\
\hline$-(\mathrm{E}+\mathrm{Al}) \# 31$ & $2 n=4 x=36$ \\
\hline$-(E+C) \# 14$ & $2 n=4 x=36$ \\
\hline$-(E+C) \# 25$ & $2 n=4 x=36$ \\
\hline$-(E+A m) \# 12$ & $2 n=4 x=36$ \\
\hline$-(E+A m) \# 13$ & $2 n=4 x=36$ \\
\hline$-(E+A m) \# 28$ & $2 n=4 x=36$ \\
\hline$-(E+A m) \# 35$ & $2 n=4 x=36$ \\
\hline$-(E+G) \# 05$ & $2 n=4 x=36$ \\
\hline$-(E+G) \# 08$ & $2 n=4 x=36$ \\
\hline$-(E+G) \# 23$ & $2 n=4 x=36$ \\
\hline$-(E+G) \# 36$ & $2 n=4 x=36$ \\
\hline
\end{tabular}

* Híbrido somático obtido por fusão química de protoplastos; $(+)$ notação recomen dada pela literatura; \# número do calo híbrido selecionado por eletroforese de proteínas e isoenzimas (Domelas et al., 1995). 

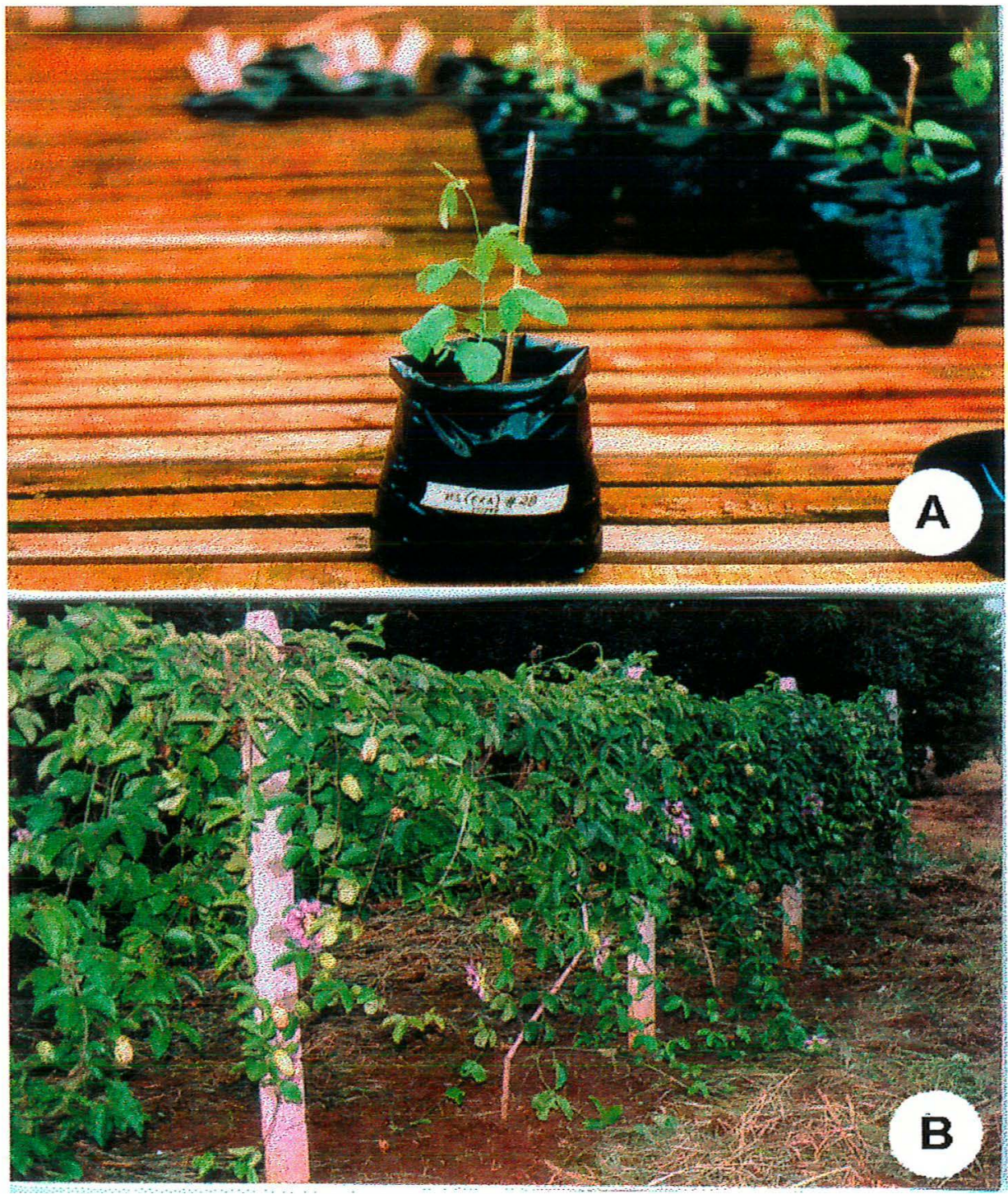

Figura 2 - Híbridos somáticos de Passiflora spp. A. (E + Am) \# 28 em fase de aclimatação na casa de vegetação. $B .(E+C)$ no campo experimental da ESALQ/USP, em Piracicaba, SP. 


\section{2 - Descrição dos parentais}

- P. edulis Sims. f. flavicarpa Degener, espécie também denominada de maracujá azedo ou maracujá amarelo; pertence ao subgênero Granadilla, série Incarnatae (Killip, 1938). É a espécie que, no Havaí e no Brasil sustenta toda a grande indústria de suco, constituindo-se assim, na espécie de maior importância econômica, uma vez que ocupa cerca de $95 \%$ dos pomares brasileiros. É de origem incerta, havendo suposições de que ela é originária da Austrália, a partir do cruzamento de $P$. edulis Sims e outra espécie estreitamente afim. No entanto, outros especialistas admitem que a forma flavicarpa é originária de uma mutação de $P$. edulis Sims (Souza \& Meletti, 1994) (Figura 3A).

- P. cincinnata Mast, pertence ao subgênero Granadilla, série Incarnatae (Killip, 1938). Originária do Nordeste brasileiro e do Estado do Mato Grosso, foi transferida para outros Estados brasileiros e também para o Paraguai, Bolívia, Argentina, Colômbia e Venezuela (Souza \& Meletti, 1994). É uma espécie selvagem, tolerante à bacteriose provocada pela Xanthomonas campestris sp. passiflorae, segunda principal doença de importância econômica para o Brasil, principalmente nas regiões Sul e Sudeste do país (Barbosa, 1995) (Figura 3B).

- P. giberti N. E. Brown, também denominada de maracujá de veado; pertence ao subgênero Granadilla, série Lobatae (Killip, 1938). A espécie é originária do Sul da América do Sul - Nordeste da Argentina (Chaco), Paraguai e Brasil Central (Souza \& Meletti, 1994). É resistente a principal doença no Brasil, a morte prematura das plantas, sendo utilizada 
como porta-enxerto para a espécie cultivada (Oliveira et al, 1983 e 1987), (Figura 3C).

- P. amethystina Mikan, pertence ao subgênero Granadilla, série Lobatae sendo uma espécie de distribuição restrita ao Brasil, na região da Serra do Mar (Killip, 1938) e de outras regiões serranas de São Paulo, Rio de Janeiro, Espírito Santo e Santa Catarina. Segundo Meletti et al. (1992), esta espécie possue grande valor ornamental, em função do seu florescimento intenso nos meses de fevereiro e março (nas condições do Estado de São Paulo) e da beleza e suavidade de suas flores (Figura 3D).

- P. alata Ait, também denominada de maracujá doce, pertence ao subgênero Granadilla, série Quadrangularis (Killip, 1938). No Brasil ocorre nos Estados do Mato Grosso do Sul, Bahia, Minas Gerais, Rio de Janeiro, São Paulo, Paraná e Santa Catarina. É encontrada também no Peru. Constitui-se na segunda espécie de importância econômica para o Brasil (Yamashiro \& Landgraff, 1979). Oliveira \& Ferreira (1991) a indicam como resistente à morte prematura das plantas, podendo assim, ser utilizada como porta-enxerto para a espécie cultivada em plantios comerciais (Figura 3E).

\section{3 - Morfologia foliar e florescimento; Comportamento cromossômico na meiose}

Os materiais apresentados na Tabela 1, após instalados no campo experimental, foram observados com relação à sua morfologia foliar e época de florescimento nos anos agrícolas de 1995/96 e 1996/97. Também foram observados alguns aspectos relacionados à polinização e frutificação dos híbridos, na presença do polinizador natural. 

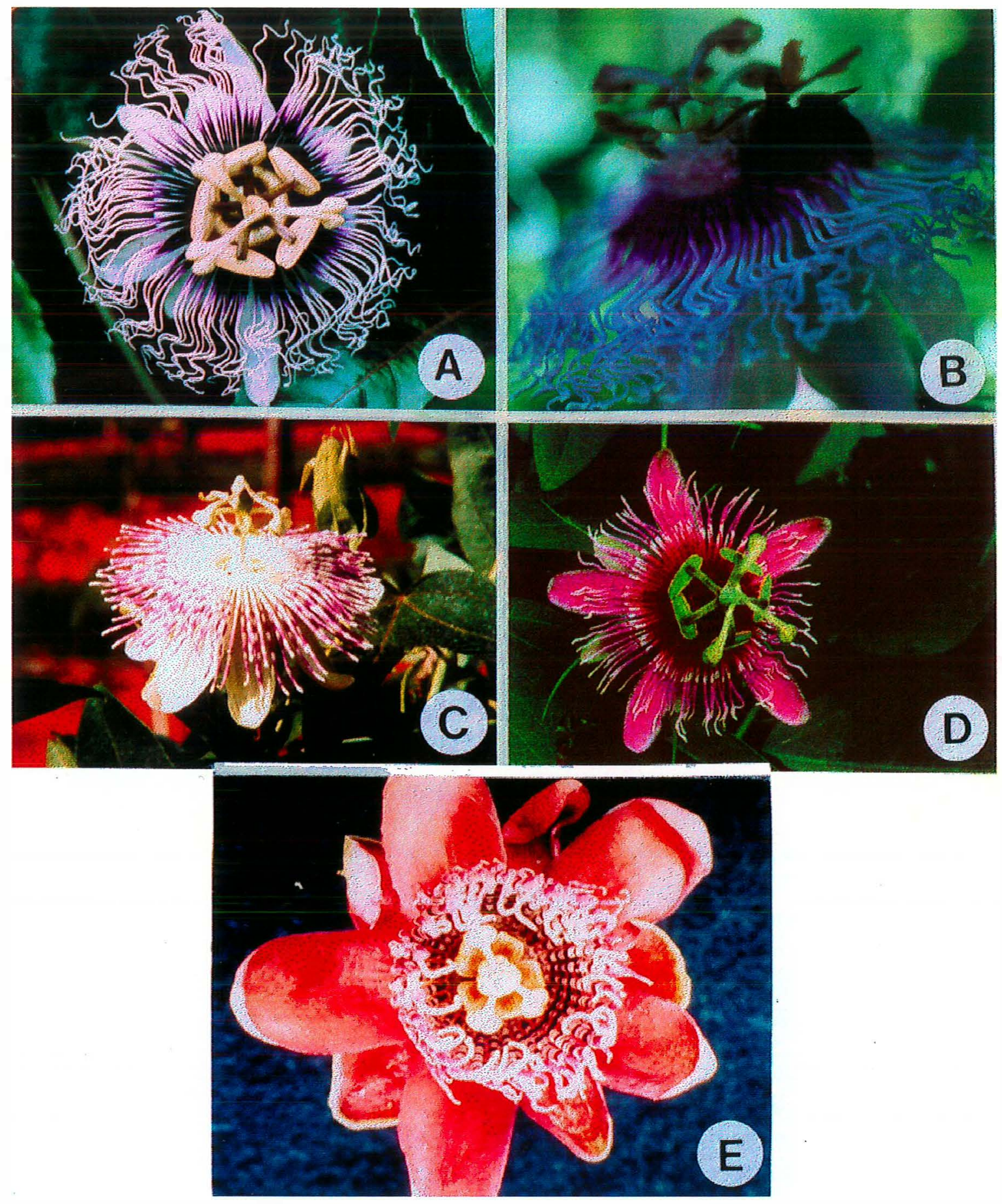

Figura 3 - Morfologia floral em Passiflora spp. A. P. edulis Sims f. flavicarpa, B. P. cincinnata, C. P. giberti, D. P. amethystina e, E. P. alata. 
Para as análises meióticas, por questões didáticas, os materiais listados na Tabela 1 foram subdivididos em grupos distintos, considerando primeiramente as espécies parentais e, em seguida, seus respectivos híbridos somáticos (Tabela 2). De cada grupo descrito, foram coletados botões florais, nas duas épocas de florescimento (1995/96 e 1996/97), no período compreendido entre 7:00 a 9:00 h, os quais foram fixados em Carnoy (3 etanol absoluto: 1 ácido acético) durante $24 \mathrm{~h}$. Após esse período, foram transferidos para etanol $70 \%(\mathrm{v} / \mathrm{v})$ e estocados em refrigerador a $5{ }^{\circ} \mathrm{C}$. Para o preparo das lâminas, realizou-se cortes nas extremidades das anteras e retirou-se os microsporócitos com auxílio de um estilete. As células foram coradas com carmim propiônico $2 \%(\mathrm{p} / \mathrm{v})$. A lâmina foi aquecida em lamparina e esmagada sob papel de filtro com leve pressão. As análises foram feitas sob microscopia ótica (Olympus BX 50) e, quando necessário, fotografadas utilizando filme kodak technical pan film TP $135-36$.

Tabela 2 - Grupos genotípicos considerando as espécies parentais e respectivos híbridos somáticos.

\begin{tabular}{|l|c|c|c|c|}
\hline \multicolumn{1}{|c|}{ Grupo 1 } & Grupo 2 & Grupo 3 & Grupo 4 & Grupo 5 \\
\hline P. edulis Sims f. flavicarpa $(\mathrm{E})$ & $(\mathrm{E}+\mathrm{Am}) \# 12$ & $(\mathrm{E}+\mathrm{C}) \# 14$ & $(\mathrm{E}+\mathrm{G}) \# 05$ & $(\mathrm{E}+\mathrm{Al}) \# 06$ \\
P. amethystina $(\mathrm{Am})$ & $(\mathrm{E}+\mathrm{Am}) \# 13$ & $(\mathrm{E}+\mathrm{C}) \# 25$ & $(\mathrm{E}+\mathrm{G}) \# 08$ & $(\mathrm{E}+\mathrm{Al}) \# 17$ \\
P. alata $(\mathrm{Al})$ & $(\mathrm{E}+\mathrm{Am}) \# 28$ & $*$ & $(\mathrm{E}+\mathrm{G}) \# 23$ & $(\mathrm{E}+\mathrm{Al}) \# 31$ \\
P. cincinnata $(\mathrm{C})$ & $(\mathrm{E}+\mathrm{Am}) \# 35$ & $*$ & $(\mathrm{E}+\mathrm{G}) \# 36$ & $*$ \\
P. giberti $(\mathrm{G})$ & $*$ & $*$ & $*$ & $*$ \\
\hline
\end{tabular}

As células foram avaliadas observando-se todos os estágios da meiose (meiose I e meiose II), bem como os produtos meióticos (formação de díades, tríades tétrades etc). Cerca de 500 células em cada fase da meiose I e II 
foram avaliadas para cada genótipo dentro de cada um dos quatro grupos descritos na Tabela 2, observando-se a porcentagem de irregularidades meióticas, presença de cromossomos atrasados com ascenção precoce e de pontes anafásicas.

Nas análises de segregação, um mínimo de 30 células no estágio de diacinese foi analisado, observando-se a ocorrência de univalentes, bivalentes e multivalentes.

\section{4 - Análise da viabilidade do grão de pólen}

Para esse estudo, fez-se uso de um corante à base das substâncias verde-malaquita e ácido fucsínico. Este método se baseia nas diferenças de coloração observadas nos grãos de pólen após tratamento com o corante, utilizando-se a concentração de $2 \%$. Quando em contato com o corante, os grãos de pólen viáveis apresentam coloração vermelha e os inviáveis, coloração acinzentada (Alexander, 1980).

Botões florais dos materiais listados na Tabela 2 foram ensacados cerca de dois dias anteriores à antese e, após abertos, foram coletados para a preparação das lâminas. Foram feitos cortes nas extremidades das anteras e os grãos de pólen retirados com o auxílio de um estilete na presença de uma gota do corante. As lâminas foram armazenadas em refrigerador por $24 \mathrm{~h}$ e analisadas sob microscópia ótica (Olympus BX 50) com a objetiva de 10X. Cerca de 10 lâminas foram preparadas e, após a varredura, estimou-se a porcentagem média de pólens viávéis.

Foram determinados os valores de correlação de Pearson entre a porcentagem média de viabilidade do grão de pólen e as irregularidades 
meióticas observadas, utilizando para isso o teste de normalidade de ShapiroWilk (SAS Institute Inc, 1988).

\section{5 - Efeito da poliploidia nas células da epiderme foliar dos} híbridos somáticos

Foram coletadas folhas jovens localizadas na porção terminal dos ramos novos dos materiais mantidos no campo experimental (Tabela 2). As epidermes inferior e superior foram separadas manualmente com auxílio de um estilete, colocando-se a epiderme inferior sobre uma lâmina de microscopia na presença de uma gota de água a qual foi coberta com lamínula. A análise consistiu em medir o comprimento e a largura das células guardas dos diplóides (parentais) e poliplóides (híbridos somáticos) em 50 campos utilizando-se uma ocular micrométrica e a objetiva de $40 \mathrm{X}$ estimando-se, posteriormente, a área média dos estômatos/campo. Procedeu-se ainda a contagem do número de estômatos por campo do microscópico, utilizando-se a objetiva de 40X, estimando-se também o número médio de estômatos/campo. Para esta última análise, um total de 100 campos/material foram analisados, procedendo-se, em seguida, a análise de variância e teste Tukey (SAS Institute Inc, 1988).

Para o efeito de comparação entre as ploidias (parentais diplóides $\mathrm{x}$ híbridos somáticos poliplóides), foi realizado uma análise de variância simples considerando o seguinte modelo matemático:

$$
y_{i j}=m+t_{i}+e_{i j}
$$

onde: 
$y_{i j}=$ é a observação do tratamento $i(i=1,2, \ldots, n)$ na repetição $j$ $(\mathrm{j}=1,2, \ldots, \mathrm{r})$;

$\mathrm{m}=$ é a média geral do experimento;

$\mathrm{t}_{\mathrm{i}}=$ é $\mathrm{o}$ efeito do tratamento (genótipos diplóides $\mathrm{x}$ poliplóides);

$e_{i j}=$ é o erro experimental associado a observação $y_{i j}$

Por não apresentarem normalidade os dados referentes à área média e número médio de estômatos foram transformados em $\sqrt{(x+0,5)}$.

Em seguida a análise de variância, procedeu-se o teste de Tukey para avaliar a significância da comparação entre as médias, nos níveis usuais de probabilidade ( $1 \%$ e $5 \%)$. 


\section{4 - RESULTADOS E DISCUSSÃO}

A apresentação dos resultados obtidos no presente trabalho, bem como a concernente discussão terá a seguinte seqüência: primeiramente, serão apresentados os dados, embora preliminares, referentes a morfologia foliar e época de florescimento das espécies parentais e dos seus respectivos híbridos somáticos e, em seguida, os resultados referentes ao estudo do comportamento meiótico, viabilidade do grão de pólen e efeitos da poliploidia sobre as células guardas dos estômatos.

\section{1 - Morfologia foliar e florescimento}

Os resultados da avaliação das características foliares dos híbridos somáticos revelou que os híbridos $(E+A m)$ e $(E+C)$ apresentam características intermediárias às espécies parentais (Figura 4.1), enquanto os híbridos $(E+G)$ apresentam características semelhantes à espécie $P$. giberti e os híbridos $(\mathrm{E}+\mathrm{Al})$, características semelhantes à espécie $P$. alata (Figura 4.2). 

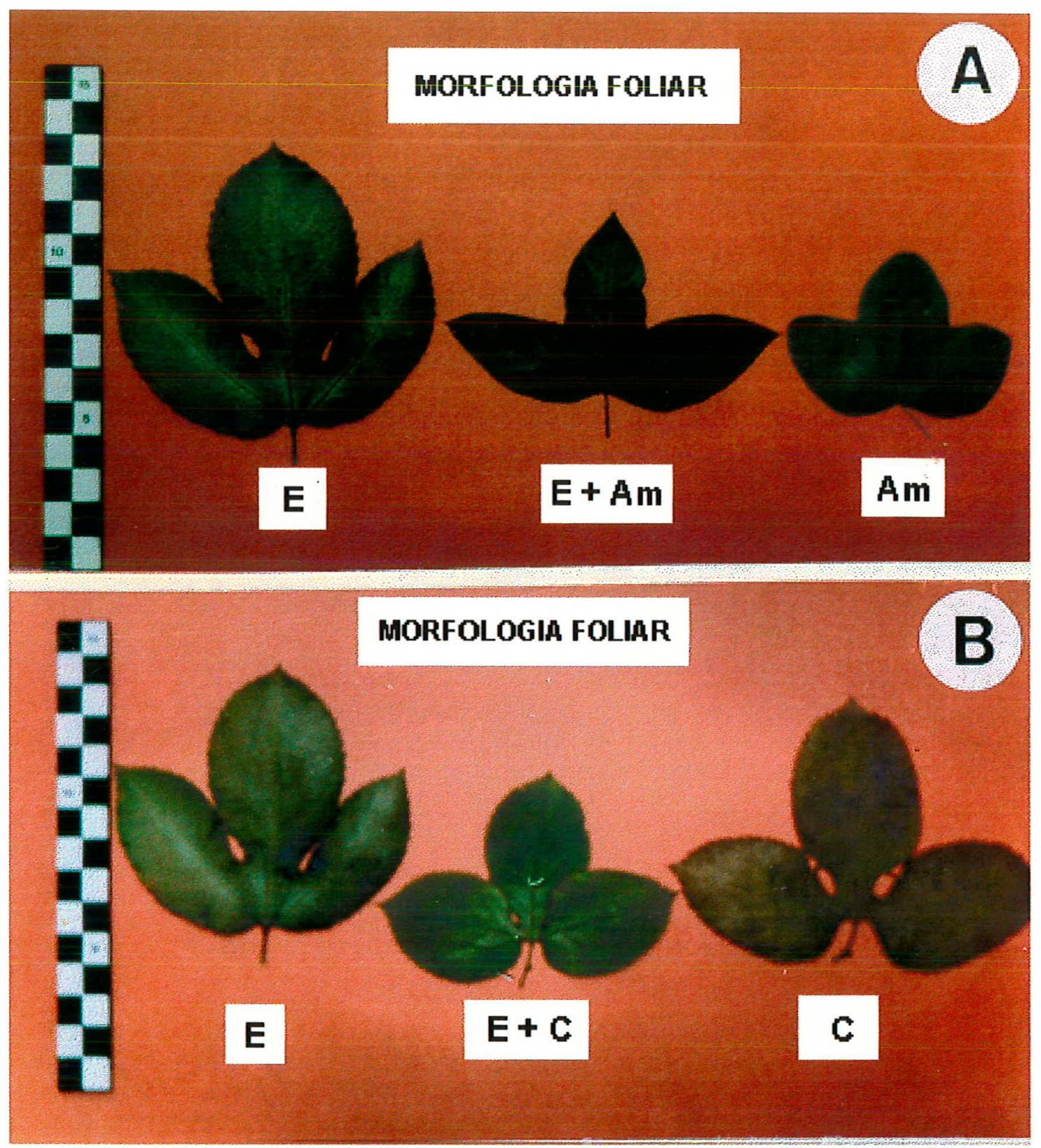

Figura 4.1 - Aspectos da morfologia foliar em Passiflora edulis Sims f. flavicarpa (E), $P$. amethystina $(\mathrm{Am}), P$. cincinnata $(\mathrm{C})$ e dos respectivos híbridos somáticos $(\mathrm{E}+\mathrm{Am})$ e $(\mathrm{E}+\mathrm{C})$. 

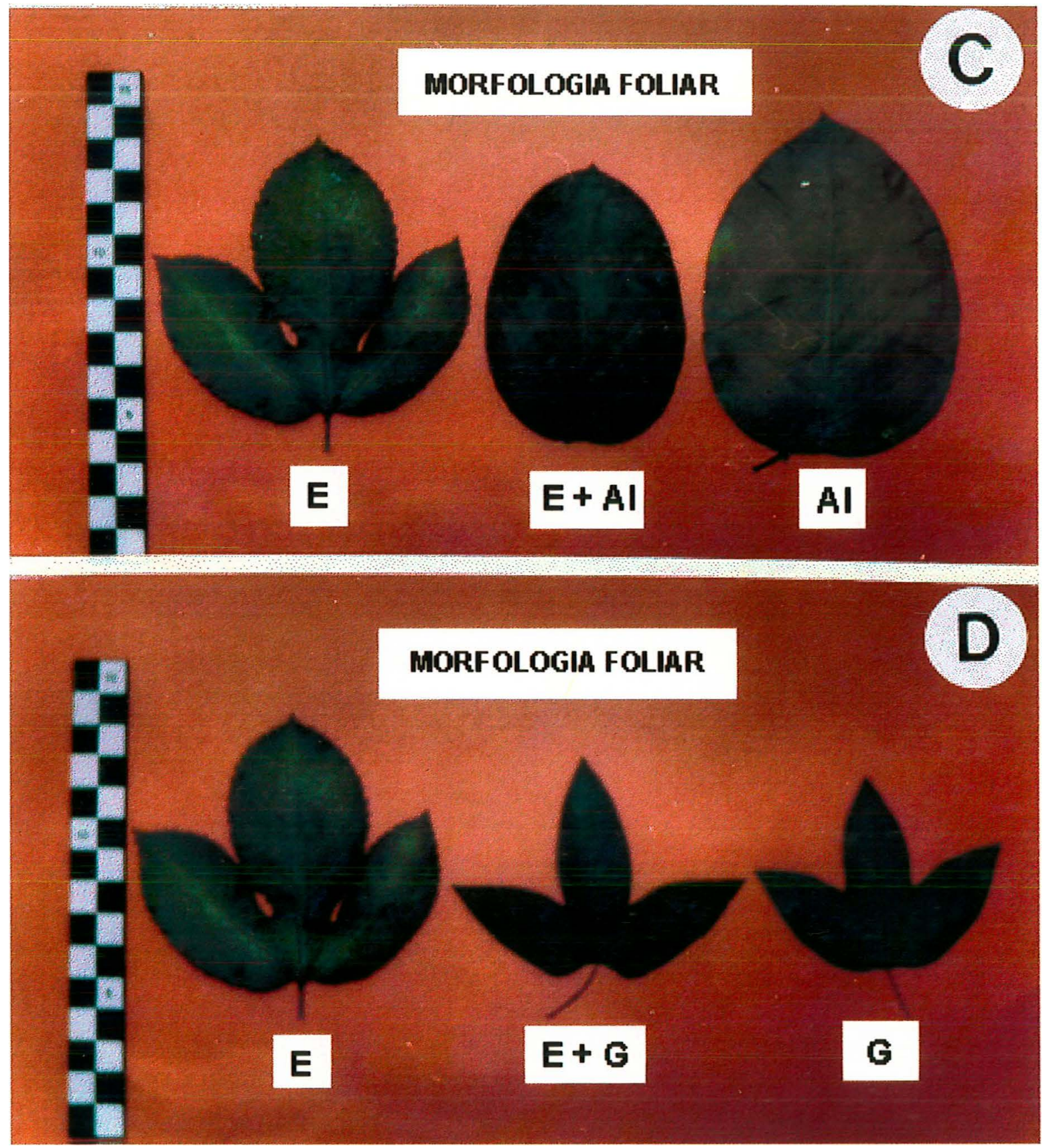

Figura 4.2 - Aspectos da morfologia foliar em Passiflora edulis Sims f. flavicarpa (E), P. alata $(\mathrm{Al}), P$. giberti $(\mathrm{G})$ e dos respectivos híbridos somáticos $(\mathrm{E}+\mathrm{Al})$ e $(\mathrm{E}+\mathrm{G})$. 
Geralmente os híbridos somáticos ou sexuais mostram características fenotípicas intermediárias em às espécies parentais (Lefol et al., 1997). Pode-se citar alguns exemplos: Otoni et al., (1995) estudando características morfológicas em híbridos somáticos obtidos via eletrofusão entre as espécies $P$. edulis Sims. f. flavicarpa e $P$. incarnata puderam observar essa tendência. Em Medicago spp, híbridos somáticos obtidos por fusão química de protoplastos apresentam igualmente características morfológicas intermediárias às espécies parentais. Entretanto, para algumas características como tempo de abertura de botão floral, algumas plantas apresentavam-se semelhantes a um dos parentais (Pupilli et al., 1995). Em citros, esse padrão intermediário em relação à morfologia foliar também foi presente (Grosser et al., 1996).

Menke et al. (1996), estudando híbridos somáticos de Solanum spp., também observaram, em termos de morfologia foliar, um padrão intermediário às formas parentais, porém $50 \%$ das plantas mostravam uma morfologia foliar semelhante à um dos parentais. Já Taguchi et al. (1993) estudando o desenvolvimento reprodutivo em híbridos somáticos de Petunia spp., relataram que, dos cinco híbridos regenerados, três deles apresentavam características intermediárias à dos parentais, enquanto os dois restantes, morfologia semelhante à do parental selvagem.

Skarzhinskaya et al. (1996), estudando híbridos somáticos intertribais entre Brassica napus e Lesquerella fendleri, puderam igualmente observar uma grande variação nas características foliares e florais entre as plantas analisadas.

Os dados referentes à época de florescimento dos parentais e respectivos híbridos somáticos nos anos de 199596 e 1996/97 estão presentes na Tabela 3. É interessante notar que, houve um comportamento semelhante dos parentais nas duas épocas de avaliação, tanto para florescimento como para 
frutificação. Embora todas as espécies tenham florescido (Figura 5), as espécies P. amethystina e $P$. cincinnata não frutificaram.

No caso do maracujazeiro, a baixa frutificação está relacionada com à polinização, fecundação e condições climáticas. Por exemplo, a influência da umidade na frutificação é decisiva. A frutificação apenas ocorre se os estigmas permanecerem secos pelo menos duas horas após a polinização.

Plantações sujeitas à sucessivas aspersões ou aguaceiros durante o dia podem apresentar uma frutificação redurida. Outra causa provável da ausência de frutificação é a redução da atividade ou ausência dos insetos polinizadores nessas condições.

Um ponto a ser considerado é que, dado o excesso de chuvas que ocorreu durante essas duas épocas de avaliação na região. Esta foi, provavelmente, a causa da baixa frutificação observada nesses materiais. Uma das estratégias utilizadas pelos agricultores para superar tais problemas tem sido a polinização artificial com o uso de dedeiras de flanela (Medina, 1980).

Os híbridos somáticos $(\mathrm{E}+\mathrm{Al})$ e $(\mathrm{E}+\mathrm{G})$ apresentaram comportamento semelhante para as duas características, sendo observada a formação de frutos com sementes viáveis. Já para os híbridos $(E+A m)$ e $(E+$ C), houve a formação de alguns frutos que inicialmente apresentavam desenvolvimento normal porém, à medida que o fruto ia se desenvolvendo, esses apresentaram um murchamento precoce com a não formação de sementes viáveis (Figura 6). 


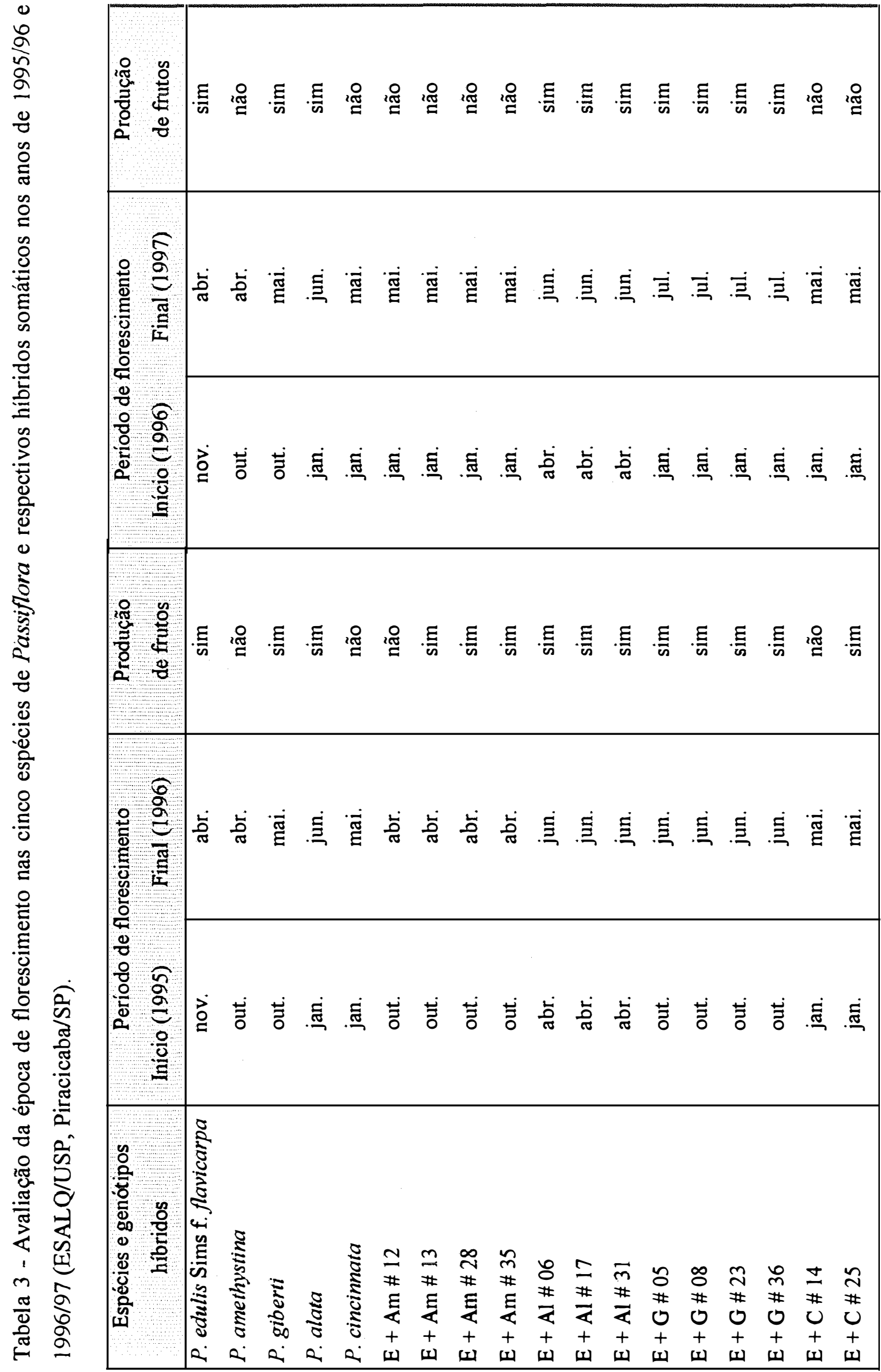



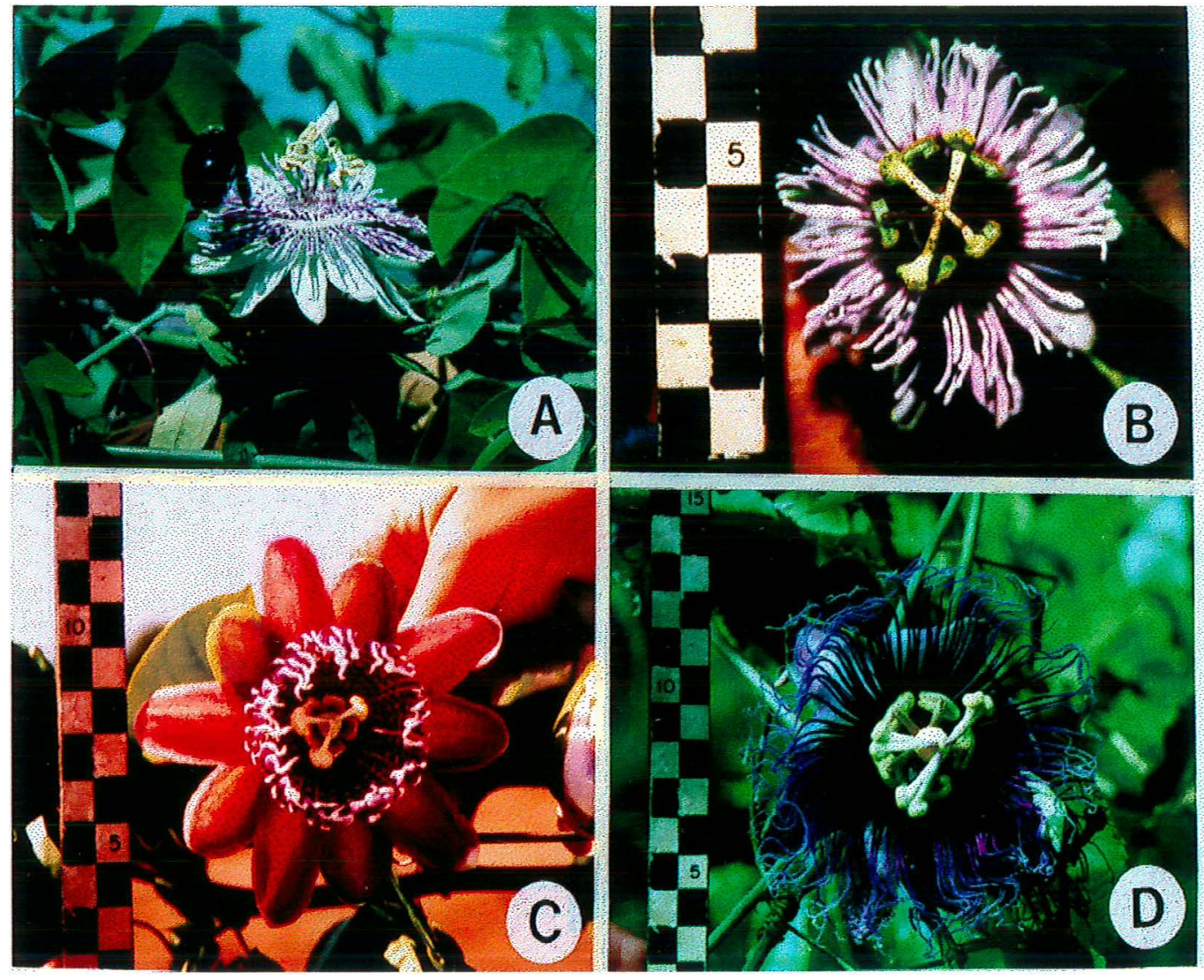

Figura 5 - Morfologia floral dos híbridos somáticos. A. $(E+G)$, B. $(E+A m), C$. $(\mathrm{E}+\mathrm{Al}) \mathrm{e}, \mathrm{D} .(\mathrm{E}+\mathrm{C})$. 


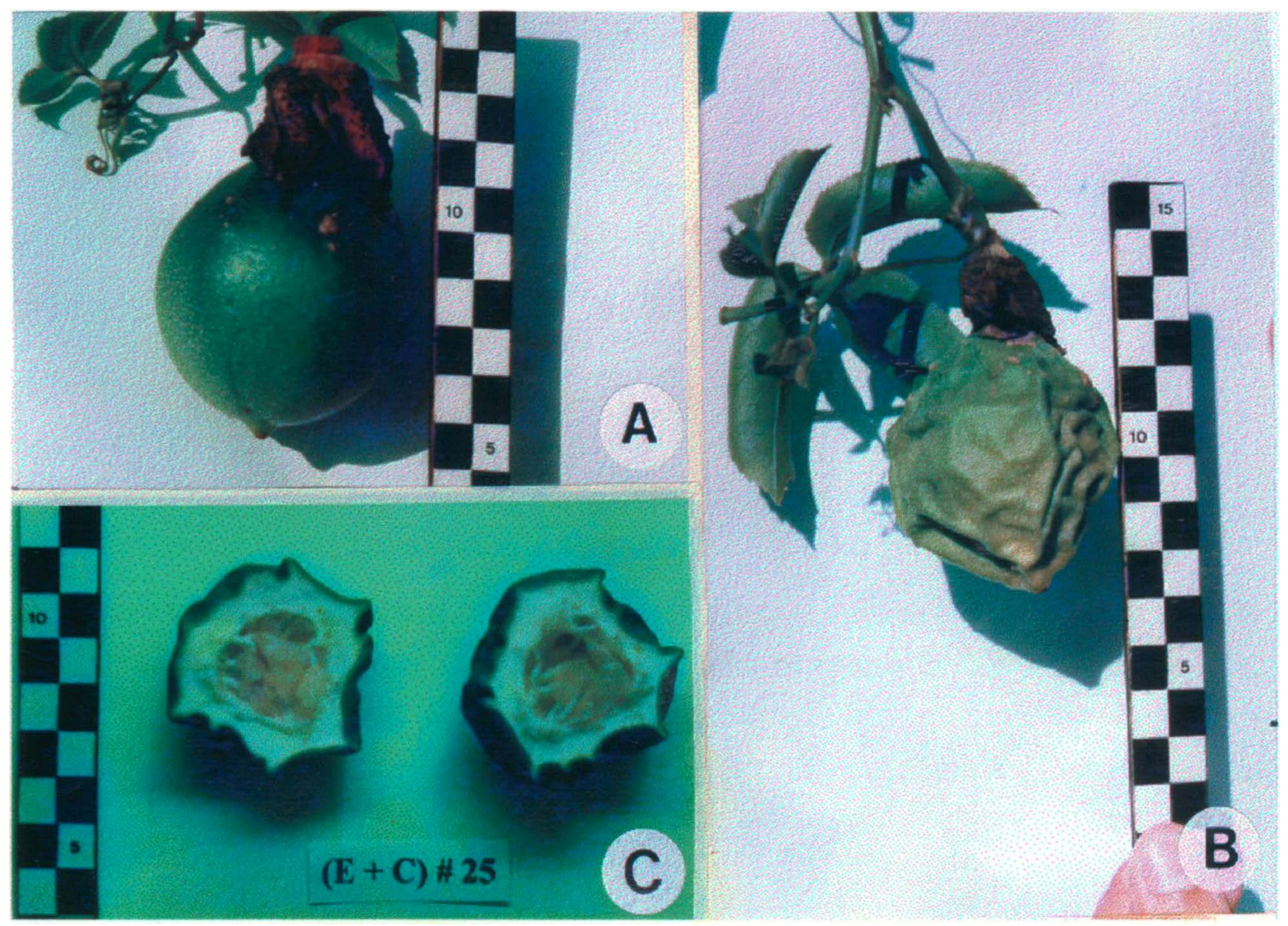

Figura 6 - Desenvolvimento de fruto em $(E+C) \# 25$ no qual se observa a formação de sementes anormais. 


\section{2 - Comportamento cromossômico na meiose}

\subsection{1 - Análise meiótica das espécies parentais (grupo 1)}

As análises meióticas das espécies parentais $P$. edulis Sims. $\mathrm{f}$. flavicarpa (E), P. alata (Al), P. amethystina (Am), $P$. giberti (G) e P. cincinnata (C) $(2 \mathrm{n}=2 \mathrm{x}=18)$, evidenciaram a presença de 9 bivalentes (Figura 7). Em $P$. edulis Sims. f. flavicarpa, foram observados dois bivalentes associados ao nucléolo em $67,0 \%$ das células, indicando a presença de duas regiões organizadoras do núcléolo (NOR). Em P. giberti, P.alata, P. cincinnata e $P$. amethystina foi igualmente observada essa tendência porém em 83, 57, 73 e $100 \%$ das células analisadas, respectivamente. Essas observações confirmam os dados descritos por Mayeda (1997) que evidenciou para essas espécies, por bandamento NOR, duas regiões organizadoras do nucléolo, uma delas localizada na constrição secundária do cromossomo 8 e a outra na região do pequeno satélite no cromossomo 9.

Como esperado, o comportamento meiótico dessas espécies foi regular porém, foi observada a presença de cromossomos atrasados, com ascenção precoce e pontes anafásicas, em uma proporção menor que $2 \%$ (Tabela 4). Chevre et al. (1994) estudando o comportamento meiótico dos híbridos somáticos entre Brassica napus + Sinapis alba e, Nagpal et al. (1996) em B. nigra, $B$. campestris e $B$. tournefortii, também observaram essa tendência, isto é, as espécies parentais mostram um comportamento cromossômico normal, formando bivalentes na metáfase I e segregação cromossômica regular na anáfase I, resultando em uma elevada viabilidade do grão de pólen. 


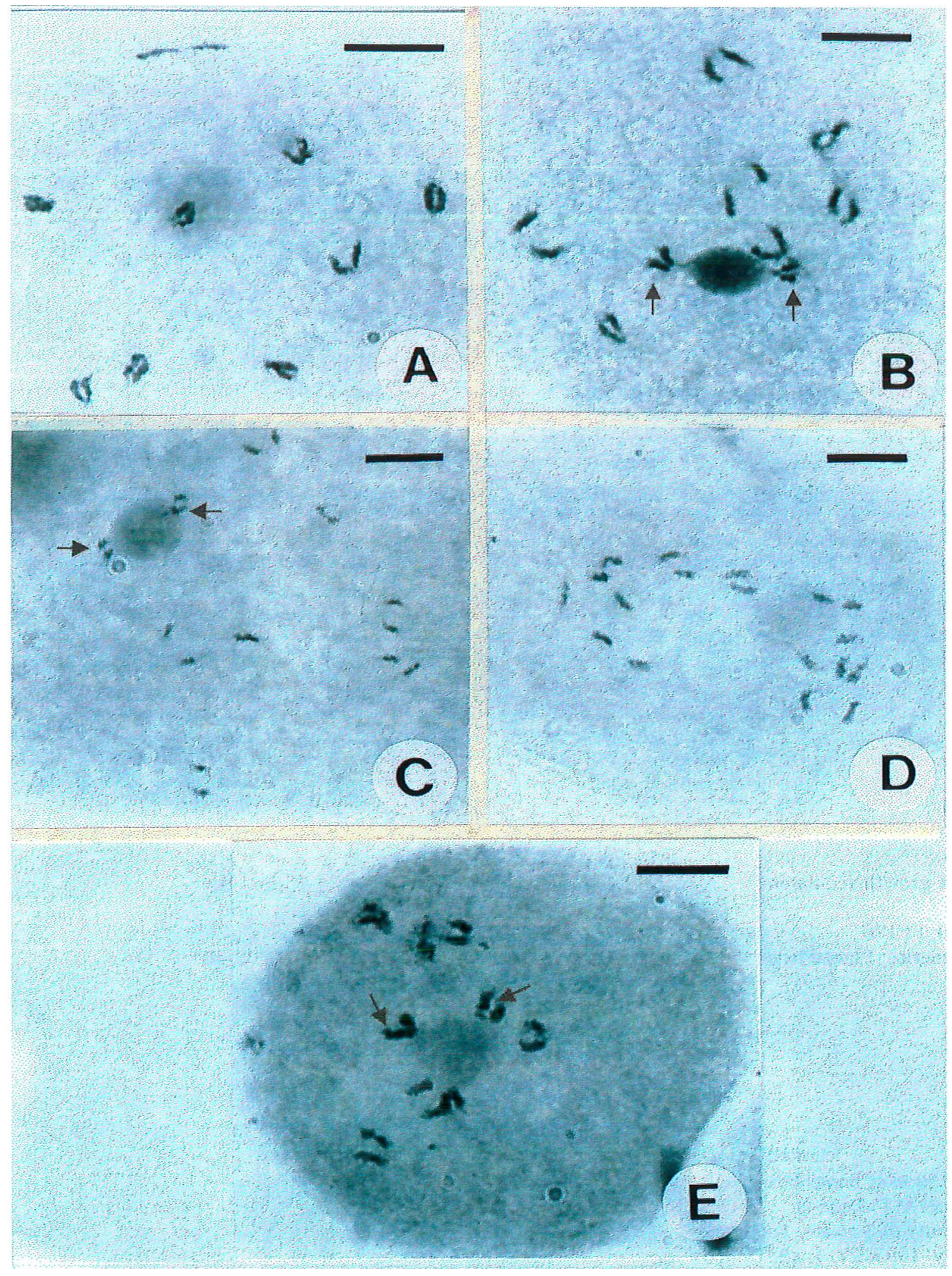

Figura 7 - Meiose em Passiflora spp. A. P. edulis Sims f. flavicarpa, B. P. alata, C. P. cincinnata, D. P. giberti e, E. P. amethystina no estágio de diacinese. Dois bivalentes associados ao nucléolo são indicados por setas em B, C e E. Barra = $10 \mu \mathrm{m}$. 


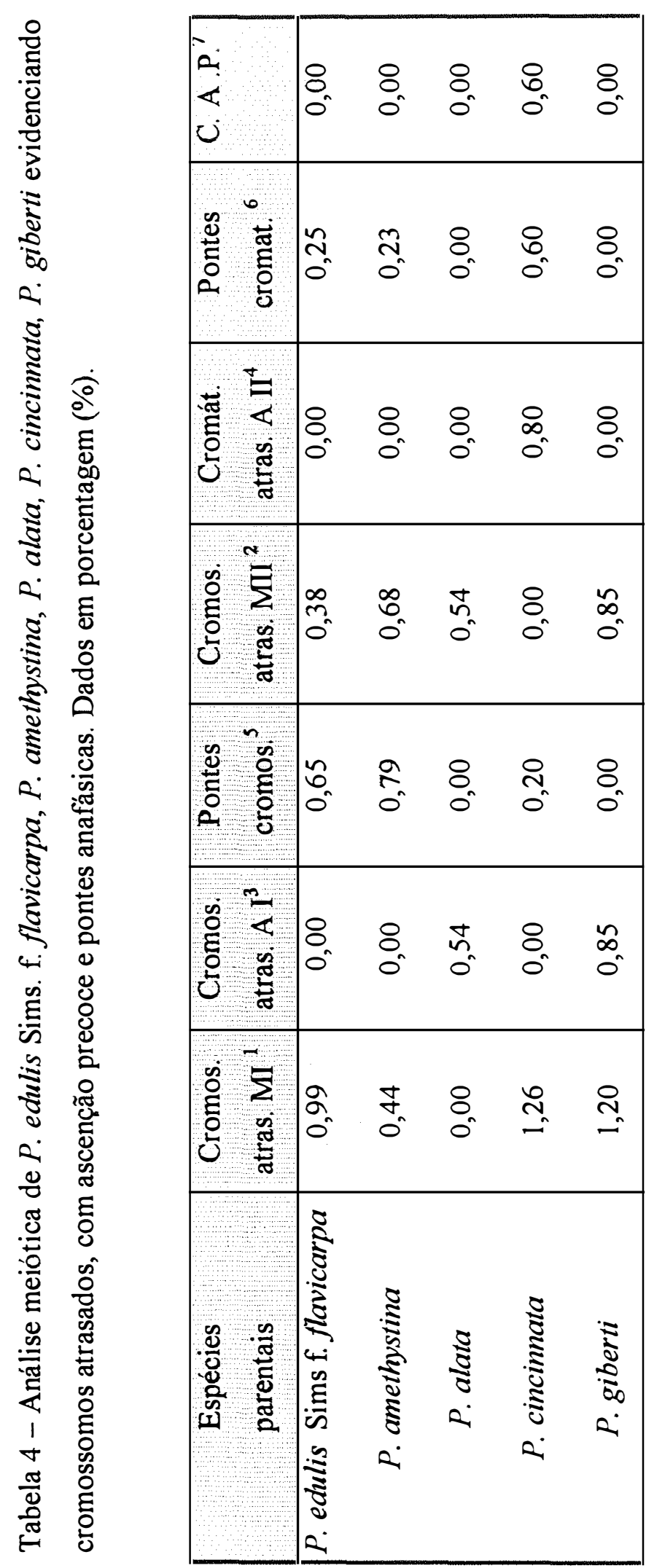

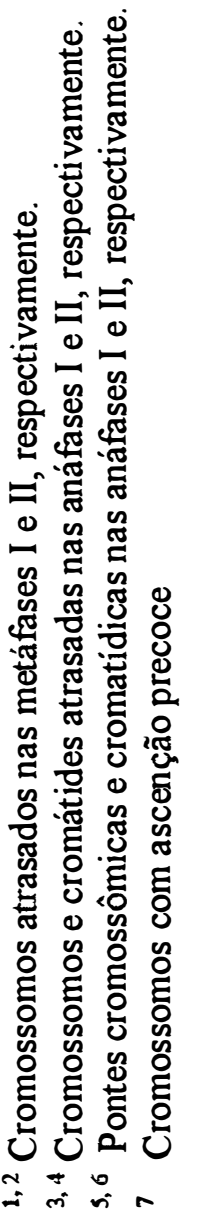




\subsection{2 - Análise meiótica dos híbridos somáticos}

\subsubsection{1 - Grupo 2 - (E+Am)}

A análise dos híbridos somáticos evidenciou $2 \mathrm{n}=4 \mathrm{x}=36$ cromossomos, não tendo sido observada a ocorrência de aneuplóides; quatro regiões organizadoras do nucléolo puderam ser observadas, o que confirmou sua natureza híbrida.

Nesses híbridos somáticos, o comportamento meiótico foi irregular, com uma alta frequência de cromossomos atrasados e pontes anafásicas em ambas as divisões meióticas (Tabela 5 e Figuras $8 \mathrm{C}$ e 8D). Pode-se observar diferenças no comportamento meiótico entre as quatro plantas híbridas analisadas: $(E+A m) \# 12$ e \# 28 apresentaram uma menor frequência de irregularidades quando comparadas a $(E+A m) \# 13$ e \# 35 .

As configurações meióticas das células híbridas em diacinese evidenciaram claramente a formação de univalentes, bivalentes e tetravalentes. Configuração do tipo trivalentes não foi encontrada (Tabela 6 e Figuras 8A e $8 \mathrm{~B})$. 

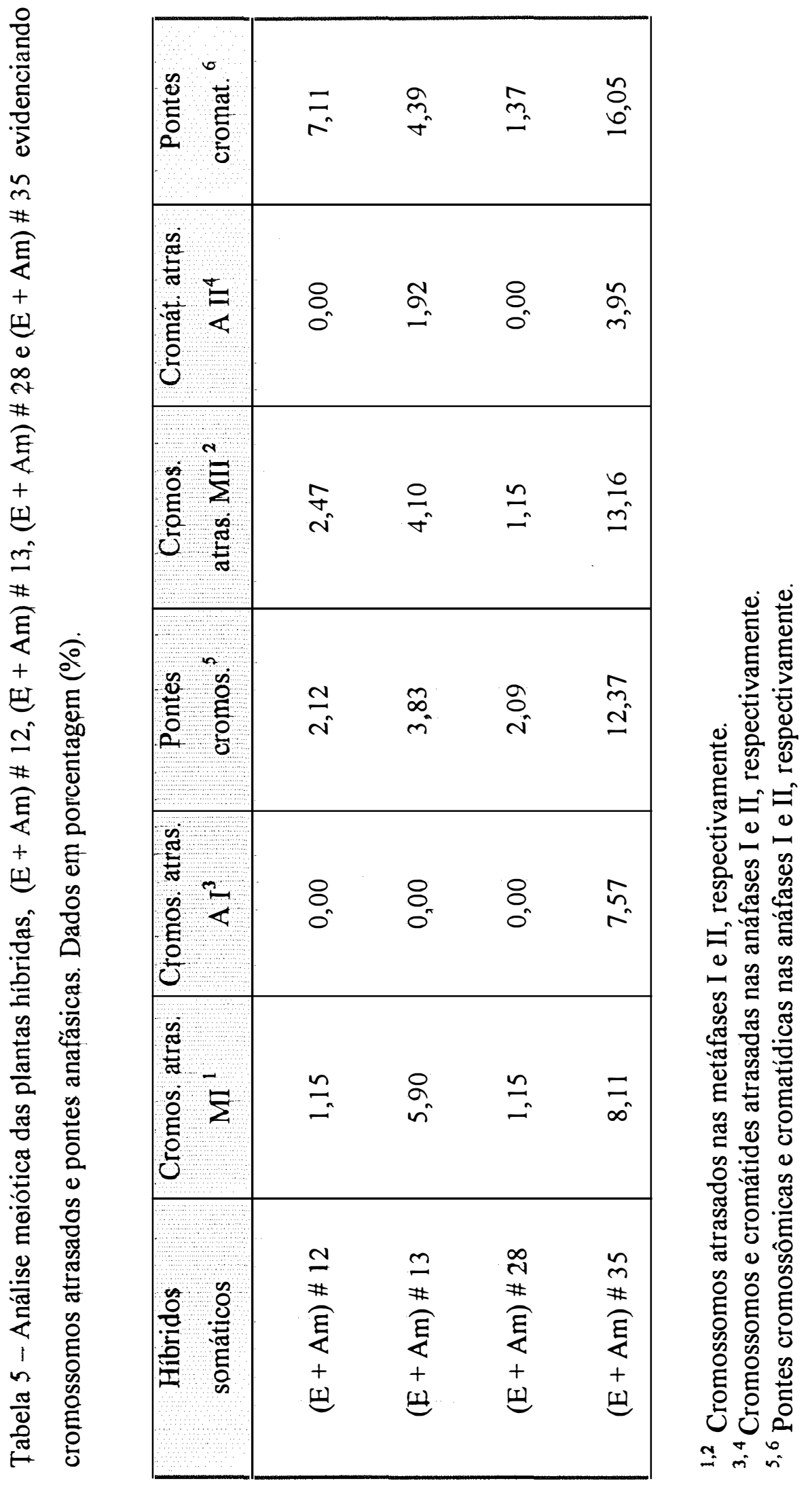


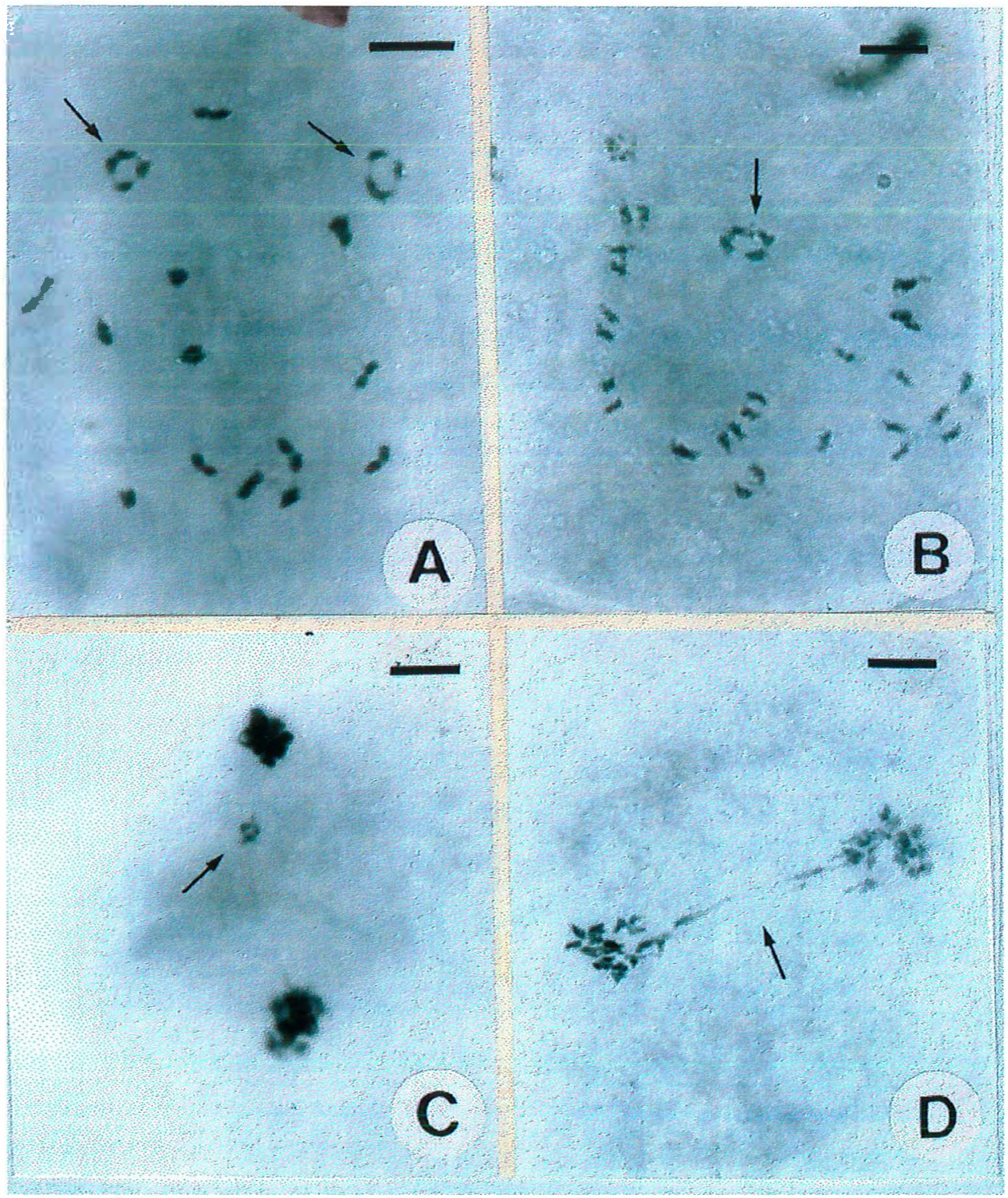

Figura 8 - Meiose em $(E+A m) \#$ 12. A. Segregação de 14 bivalentes e dois tetravalentes (setas). B. Segregação de dois univalentes, 15 bivalentes e um quadrivalente (seta). C. Presença de cromossomo atrasado (seta) e, D. ocorrência de ponte cromossômica (seta). Barra $=10 \mu \mathrm{m}$. 
Tabela 6: Segregações meióticas dos híbridos somáticos $(E+A m) \# 12, \# 13, \# 28$ e \# 35. Número de células analisadas $=30$. Dados em porcentagem $(\%)$.

\begin{tabular}{|c|c|c|c|c|c|c|c|c|}
\hline $\begin{array}{l}\text { Híbridos } \\
\text { somáticos }\end{array}$ & $\begin{array}{r}14 \mathrm{II} \\
+2 \mathrm{IV}\end{array}$ & $\begin{aligned} & 16 \mathrm{II} \\
+ & 1 \mathrm{IV}\end{aligned}$ & $\begin{array}{c}2 \mathrm{I}+15 \mathrm{II} \\
+1 \mathrm{IV}\end{array}$ & $\begin{array}{r}4 \mathrm{I}+12 \mathrm{II} \\
+2 \mathrm{IV}\end{array}$ & $\begin{array}{c}4 \mathrm{I}+14 \mathrm{II} \\
+1 \mathrm{IV}\end{array}$ & $\begin{array}{c}2 \mathrm{I}+13 \mathrm{II} \\
+2 \mathrm{IV}\end{array}$ & $\begin{array}{c}2 \mathrm{II} \\
+17 \mathrm{II}\end{array}$ & $18 \mathrm{II}$ \\
\hline $\begin{array}{c}(E+A m) \# \\
12\end{array}$ & 26,7 & 40,0 & 10,0 & 3,3 & 3,3 & 0,0 & 10,0 & 6,7 \\
\hline $\begin{array}{c}(E+A m) \# \\
13\end{array}$ & 16,7 & 43,3 & 13,3 & 0,0 & 0,0 & 0,0 & 6,7 & 20,0 \\
\hline $\begin{array}{c}E+A m) \# \\
28\end{array}$ & 30,0 & 43,3 & 20,0 & 0,0 & 0,0 & 0,0 & 0,0 & 6,7 \\
\hline $\begin{array}{c}(\mathrm{E}+\mathrm{Am}) \# \\
35\end{array}$ & 40,0 & 26,7 & 23,3 & 0,0 & 0,0 & 3,3 & 6,7 & 0,0 \\
\hline
\end{tabular}

Pode-se-observar que em $96,7 \%$ das células analisadas, nos híbridos $(E+A m) \# 12$ e \# 35, ocorreu a formação de um mínimo de 14 If, enquanto para as demais plantas híbridas, em $100 \%$ das células foi -observada a presença desses 14 II (Tabela 6). Como esperado, o pareamento ocorreu preferencialmente entre os cromossomos homólogos de cada genoma parental. De acordo com McConnell et al. (1993), a preponderância de bivalentes reflete o nível de homologia entre os cromossomos parentais.

Foi observada uma alta frequência de pelo menos um tetravalente, sendo de 73,3\% para $(E+A m) \# 13,83,3 \%$ para \# 12 e, 93,3\% para \# 28 e \# 35. Essa formação multivalente é consequência do pareamento homeólogo entre 
os cromossomos oriundos dos genomas parentais e sugerem a possibilidade de permuta e recombinação (Jong et al., 1993). Desta forma pode-se inferir que, as espécies $P$. edulis Sims. f. flavicarpa e $P$. amethystina possuem um certo grau de homeologia cromossômica, dada a formação de tetravalentes, além de possuírem cariótipos bem semelhantes (Mayeda, 1997).

Por exemplo, os cromossomos de Lycopersicon esculentum e $L$. peruvianum são bastante semelhantes, tanto em morfologia quanto tamanho. Isso indica, provavelmente, que estrutura desses cromossomos têm sido altamente conservada durante o processo evolutivo (Parokonny et al., 1997), entretanto, o mecanismo de imcompatibilidade cruzada está presente nessas espécies.

O híbrido $(E+A m) \# 28$ apresentou uma baixa frequência de cromossomos atrasados e pontes anafásicas (anáfase I e II) (Tabela 5). Já a planta $(E+A m) \# 35$ difere das demais pela elevada frequência de células com univalentes (33,3\%) (Tabela 6), o que explica o elevado nível de cromossomos e cromátides atrasadas observado durante as subsequentes fases da meiose (Tabela $5)$.

Wolters et al. (1994) estudando as anormalidades mitóticas e meióticas em híbridos somáticos entre Lycopersicon esculentum e Solanum tuberosum, encontraram univalentes, bivalentes, tetravalentes e, em algumas plantas, a ocorrência de trivalentes, concluindo que, possivelmente, ocorreu recombinação homeóloga entre os cromossomos das duas espécies. Em híbridos somáticos entre $B$. juncea e Diplotaxis harra, também foi observada essa tendência de formação de multivalentes, cromossomos atrasados e pontes anafásicas. (Olin-Fatih et al, 1996).

A formação de multivalentes em híbridos somáticos é usual. Analisando a meiose dos híbridos somáticos Brassica napus + B. oleracea, Hansen \& Earle (1997) observaram uma elevada frequência de tetravalentes, 
bivalentes e poucos univalentes. Apesar disso, o ciclo meiótico foi regular. Essa variação na frequência de multivalentes é influenciada evidentemente pelos genótipos envolvidos no processo de hibridação (Chiang et al., 1978).

A recombinação homeóloga representa uma forma de introgressão gênica (Islam \& Shepherd, 1992). O evento da permuta (ou crossing-over) faz com que segmentos de DNA possam ser introgredidos em um genoma homeólogo receptor. O cromossomo recombinante usualmente apresenta um padrão de recombinação homeólogo nas meioses subsequentes, podendo ser incorporado de forma estável nos gametas. Em híbridos alotetraplóides entre espécies diplóides aparentadas, os quatro cromossomos homeólogos podem formar tetravalentes e trocar segmentos de DNA durante a sinapse. A frequência de formação de tetravalentes na meiose é usada como um índice para indicar a afinidade entre os cromossomos parentais (Sybenga, 1975). A formação de tetravalentes na metáfase I pode ser uma fonte de aneuploidia, caso haja segregação cromossômica desigual. Isso geralmente é indesejável em materiais comerciais tetraplóides. Nessa situação, é interessante conhecer a frequência de formação de tetravalentes e quais os crmossomos envolvidos no pareamento tetravalente (Sybenga et al., 1994).

\subsubsection{2 - Grupo 3 - $(E+C)$}

A análise dos dois híbridos somáticos $(E+C) \# 14$ e \# 25 também evidenciou $2 n=4 x=36$ cromossomos, sem a ocorrência de aneuplóides; foram observadas quatro regiões organizadoras do nucléolo, confirmando a sua natureza híbrida. Os dados referentes à análise meiótica estão apresentados na Tabela 7. 


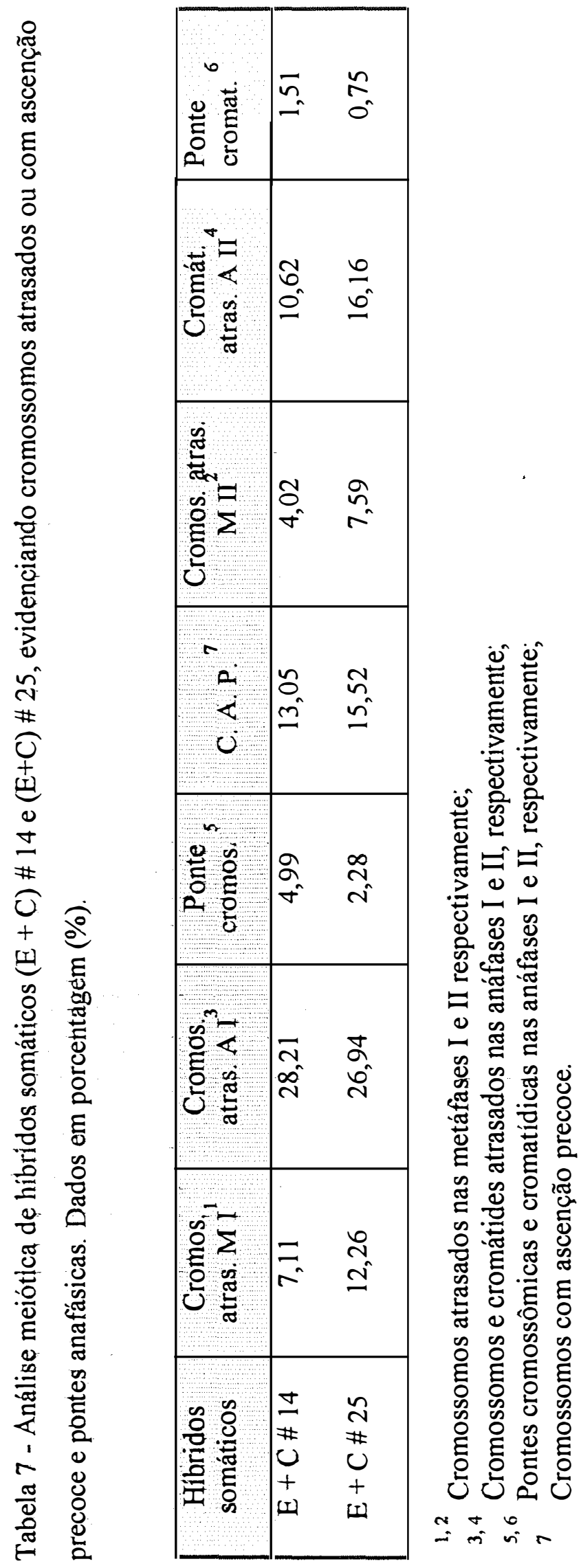


Pôde-se observar que esses híbridos igualmente apresentam uma meiose irregular, com presença de cromossomos atrasados, pontes anafásicas e de cromossomos com ascenção precoce (Figuras 9C a 9F). Na Tabela 4, pode-se verificar que a espécie $P$. cincinnata mostra também cromossomos com ascenção precoce porém, em uma porcentagem menor que $1 \%$.

Em termos comparativos, ambas as plantas possuem meiose irregular e, bem semelhante. É interessante notar que as proporções de cromossomos atrasados e com ascenção precoce na anáfase I são praticamente as mesmas em ambos os híbridos.

Esse comportamento é bem diferente do apresentado pelos híbridos $(E+A m)$, no qual cada planta híbrida mostrou comportamento meiótico bem diferenciado (Tabela 5).

Essa semelhança nas porcentagens de irregularidades meióticas é algo comum em se tratando de híbridos somáticos. Em Medicago (Pupilli et al., 1992, 1995), Solanum (Conicella et al., 1997), Brassica (Olin-Fatih et al, 1996; Nagpal et al, 1996), a maioria das plantas híbridas regeneradas apresentam porcentagens de irregularidades semelhantes. Em Brassicas, especificamente, Nagpal et al. (1996) observaram que os cinco híbridos somáticos obtidos apresentavam as mesmas proporções de irregularidades, além da predominância de bivalentes na metáfase I, com poucos univalentes.

As configurações meióticas presentes nas células em diacinese evidenciaram uma elevada porcentagem de 18 II (Tabela 8 e Figuras 9A e 9B) porém, foi igualmente observada uma baixa ocorrência de tetravalentes e univalentes (menor do que 20,0 \%). Pôde-se notar esporócitos com micronúcleos (Tabela 9 e Figura 10), o que deve ser devido à ocorrência de cromossomos atrasados ou com ascenção precoce (Tabela 7). 
Tabela 8 - Segregações observadas na meiose dos híbridos somátioos $(E+C) \# 14$ e $(E$ + C) \# 25. Dados em porcentagem (\%).

\begin{tabular}{|c|c|c|c|c|}
\hline Híbridos & Número de células & $16 \mathrm{I}+1 \mathrm{IV}$ & $2 \mathrm{I}+17 \mathrm{II}$ & $18 \mathrm{II}$ \\
\hline $\mathrm{E}+\mathrm{C} \# 14$ & 70 & 17,14 & 4,28 & 78,57 \\
$\mathrm{E}+\mathrm{C} \# 25$ & 60 & 13,33 & 15,00 & 71,67 \\
\hline
\end{tabular}

Tabela 9 - Análise de esporócitos $(E+C) \# 14$ e $(E+C) \# 25$, evidenciando a ocorrência de micronúcleos. Dados em porcentagem $(\%)$.

\begin{tabular}{|c|c|c|c|}
\hline Híbridos & Número de células & 4 células filhas & +4 células filhas \\
\hline E + C \# 14 & 827 & 93,60 & 6,40 \\
E + C \# 25 & 935 & 91,34 & 8,66 \\
\hline
\end{tabular}

Pelos dados mostrados na Tabela 8, pode-se observar uma tendência na formação de bivalentes (porcentagem maior que $70,0 \%$ e de poucos univalentes e tetravalentes. No-híbrido $(E+C) \# 14$, a porcentagem de univalentes e tetravalentes foi de 21,42\% e no $(E+C)$ \# 25 de 28,33. Se não há pareamento entre os cromossomos homeólogos, ou seja, entre os cromossomos parentais, tais híbridos se comportam, em termos de segregação cromossômica, como diplóides. Como ocorreu a formação de tetravalentes, o arranjo desses na metáfase pode ser de tal natureza que resulte em uma segregação irregular dos cromossomos, originando bivalentes e univalentes. Como resultado final dessa distribuição irregular, formaram-se tétrades anormais, apresentando micronúcleos que provavelmente originarão gametas aneuplóides (Figura 10). 


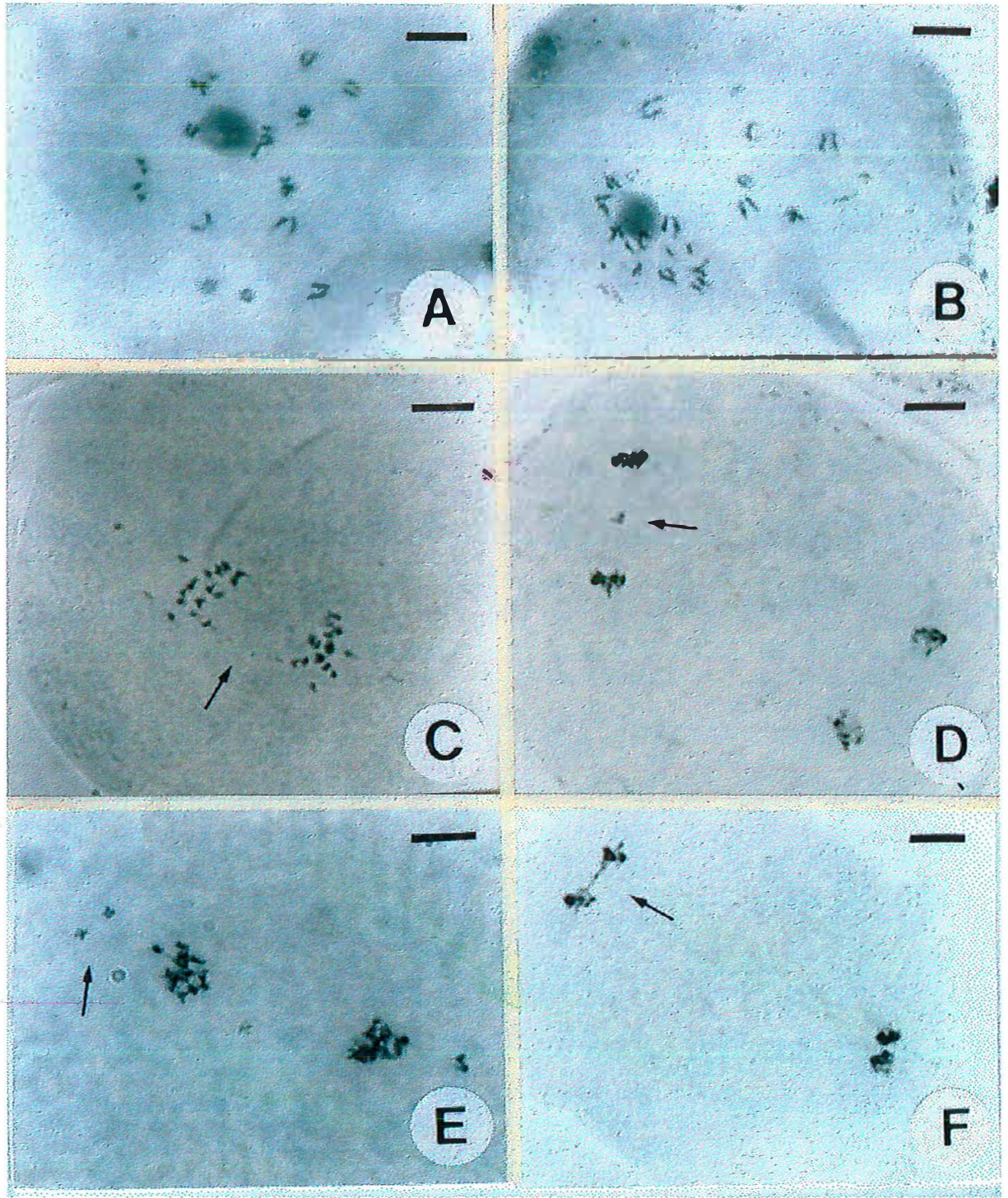

Figura 9 - A e B. Meiose em (E + C) \# 25 e \# 14, ambos com segregação de 18 bivalentes. C. Presença de pontes cromossômicas (seta). D. Ocorrência de cromátide atrasada (seta). E. Presença de cromossomos com ascenção precoce (seta). F. Ocorrência de ponte cromatídica (seta). Barra $=10 \mu \mathrm{m}$. 


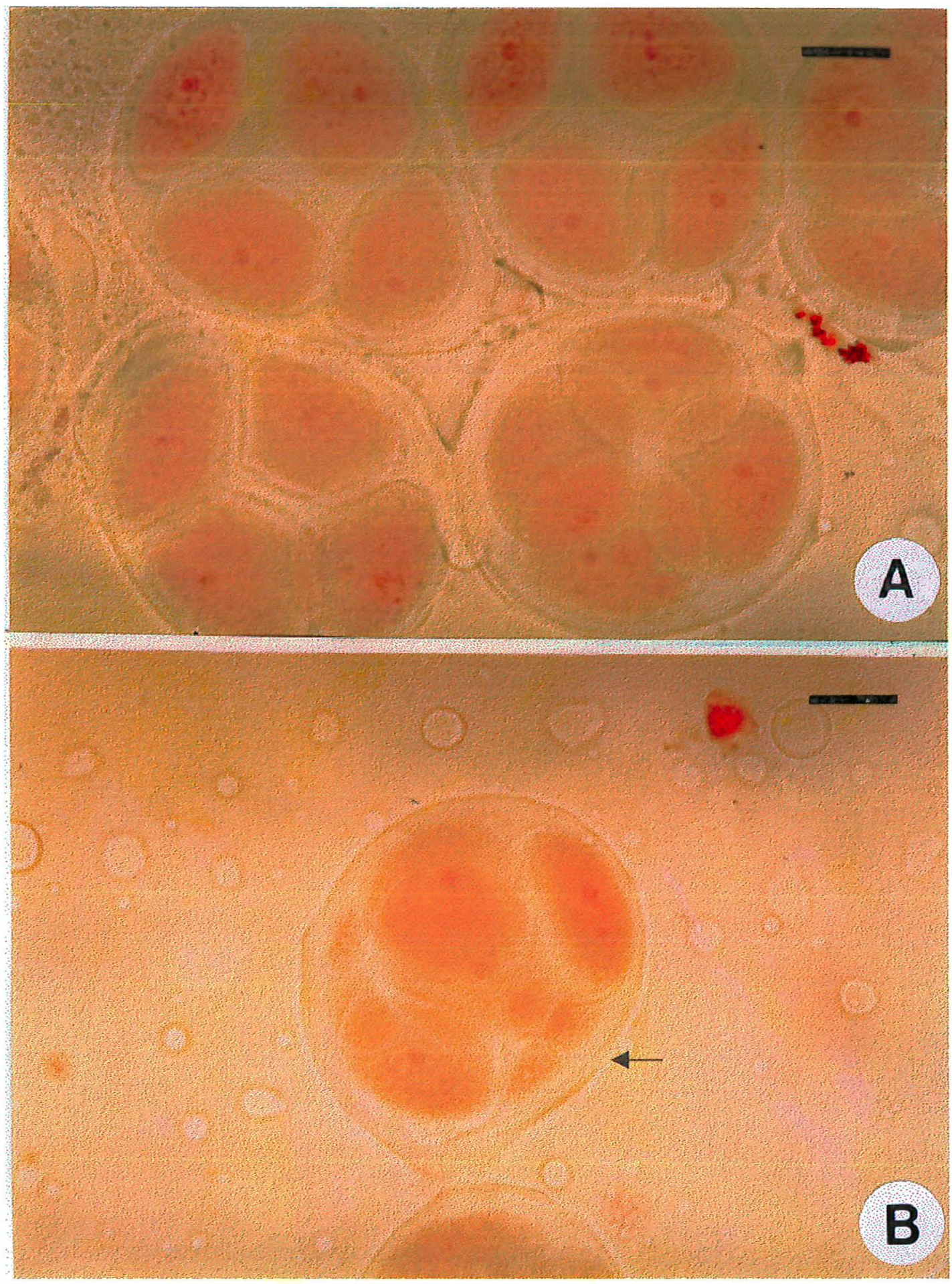

Figura 10 - A. Tétrades normais em $(E+C) \# 14$. B. Presença de micronúcleos em $(\mathrm{E}+\mathrm{C}) \# 25$ (seta). Barra $=30 \mu \mathrm{m}$. 
A presença de univalentes mostra uma correlação negativa com fertilidade, uma vez que não passam por uma disjunção regular na meiose. Como consequência, são formados micrósporos com um número não balanceado de cromossomos, resultando em aborto do pólen (Pagliarini, 1989; Lawrence, 1980). Isso vem de acordo com os dados apresentados na Tabela 9, uma vez que foram encontrados meiócitos com micronúcleos.

Pelas Tabelas 7 e 9, pode-se verificar que a frequência de micrósporos com micronúcleos foi bem inferior à esperada com base nas anormalidades observadas nas fases anteriores. Esses dados mostram que apesar de ocorrer uma elevada porcentagem de cromossomos atrasados e com ascenção precoce, esses foram incluídos nos núcleos telofásicos. Situação semelhante tem sido encontrada e discutida em milho (Pagliarini, 1989).

Pela Tabela 8, pode-se afirmar que, como ocorreu a formação de tetravalentes e univalentes, os genomas parentais possuem alguma homeologia, havendo assim a possibilidade de ocorrer recombinação através do crossing-over. porém, mais de $70 \%$ das células apresentaram bivalentes.

Para híbridos somáticos entre Brassica oleraceae e Sinapis alba, Hansen \& Earle (1997) observaram uma tendência de formação de bivalentes na meiose com ocorrência casual de univalentes. Como houve a formação de univalentes, provavelmente ocorreu pareamento homeólogo entre os cromossomos dos genomas parentais, indicando que tais híbridos se comportam como alopoliplóides segmentais. De acordo com Stebbins (1950), um alopoliplóide segmental contém dois genomas que possuem em comum, um considerável número de segmentos cromossômicos homólogos, mas diferem um do outro com respeito ao número de genes presentes nesses segmentos.

A ação dos mecanismos envolvidos no controle genético do pareamento cromossômico em híbridos somáticos ainda é desconhecida. Já em alopoliplóides, sabe-se que existe um controle genético atuando na formação de 
quiasmas entre os cromossomos homólogos de cada espécie na prófase I da meiose. Como resultado, somente bivalentes são formados.

Em outras espécies alopoliplóides, a sinapse também é restrita aos cromossomos homólogos oriundos de cada complemento genômico, ocorrendo somente a formação de bivalentes. Diferenças nas relações filogenéticas entre espécies distintas podem afetar esse pareamento homólogo em outros alopoliplóides, como Festuca e Aegilops (Thomas \& Thomas, 1993; Cunado et al., 1996).

A exemplo do que ocorre no trigo tetraplóide Triticum turgidum, esses genes são denominados de "genes que controlam o pareamento" (gene dominante supressor $P h l$ presente no cromossomo 5 e genes menores supressores localizados em outros cromossomos). Esses genes impedem o pareamento entre cromossomos homeólogos. O mesmo mecanismo é observado no trigo tetraplóide Triticum aestivum $(2 \mathrm{n}=6 \mathrm{x}=42)$ (Dvorak, 1983).

Uma outra explicação sobre a predominância de bivalentes é aquela presente no trigo alohexaplóide Triticum aestivum. É interessante mencionar essa espécie uma vez que, a característica principal do zigóteno é a formação de multivalentes porém, na metáfase I ocorrem bivalentes. Nesse caso, durante o paquíteno, a maioria dos multivalentes são "transformados" em bivalentes homólogos (ou seja, formam-se bivalentes pelo pareamento homólogo e também pela eliminação de multivalentes). Esse fenômeno ocorre em um estágio anterior ao crossing-over. Esse mecanismo garante a segregação regular dos cromossomos e a herança dissômica do organismo (McGuire \& Dvorak, 1982).

\subsubsection{3 - Grupos 4 e 5 - $(E+A L)$ e $(E+G)$}

O comportamento cromossômico para os híbridos somáticos (E + $\mathrm{G})$ e $(\mathrm{E}+\mathrm{Al})$ foi regular (Tabela 10 e Figuras 11 e 12), sendo observadas poucas 
irregularidades meióticas. Esse comportamento, em termos comparativos, é semelhante ao das espécies $P$. giberti e $P$. alata (Tabela 4), nos quais a maioria das irregularidades ocorreu em proporção menor do que $2 \%$.

Em termos de segregação cromossômica, todos os híbridos listados na Tabela 10 apresentaram $2 \mathrm{n}=2 \mathrm{x}=18$ cromossomos, com configuração de nove bivalentes (Tabela 11 e Figuras $11 \mathrm{~B}$ e $12 \mathrm{~A}$ ).

Desses híbridos, apenas a planta $(E+G)$ \# 05 chama a atenção pela porcentagem de cromossomos atrasados em metáfase I (5,50 \%) (Figura 11D), sendo essa irregularidade característica da espécie $P$. giberti. Outras irregularidades como a presença de pontes cromossômicas (Figura 11E) e cromátides atrasadas (Figura 11I) também ocorreram porém, houve a formação de tétrades normais sem a presença de micronúcleos.

Comportamento similar foi apresentado pelos híbridos $(\mathrm{E}+\mathrm{Al})$, com destaque para o $(\mathrm{E}+\mathrm{Al}) \# 06$. Neste híbrido, também foram encontradas irregularidades meióticas (Figura 12) com formação de tétrades normais.

O fato de os híbridos $(E+G)$ e $(E+A l)$ mostrarem $2 n=2 x=18$ cromossomos mitóticos (dados não apresentados nesta tese) e nove bivalentes na meiose I (Tabela 11) sugere ter havido perda de um dos lotes ou complementos cromossômicos. Esses híbridos foram selecionados na fase de calo com base em análises do padrão de proteínas e isoenzimas. Os calos foram selecionados porque mostravam um padrão de bandas híbrido equivalente ao da mistura das amostras parentais (Dornelas et al., 1995). Os brotos regenerados a partir desses calos foram aclimatados e levados a campo constituindo o material analisado nesse estudo. 


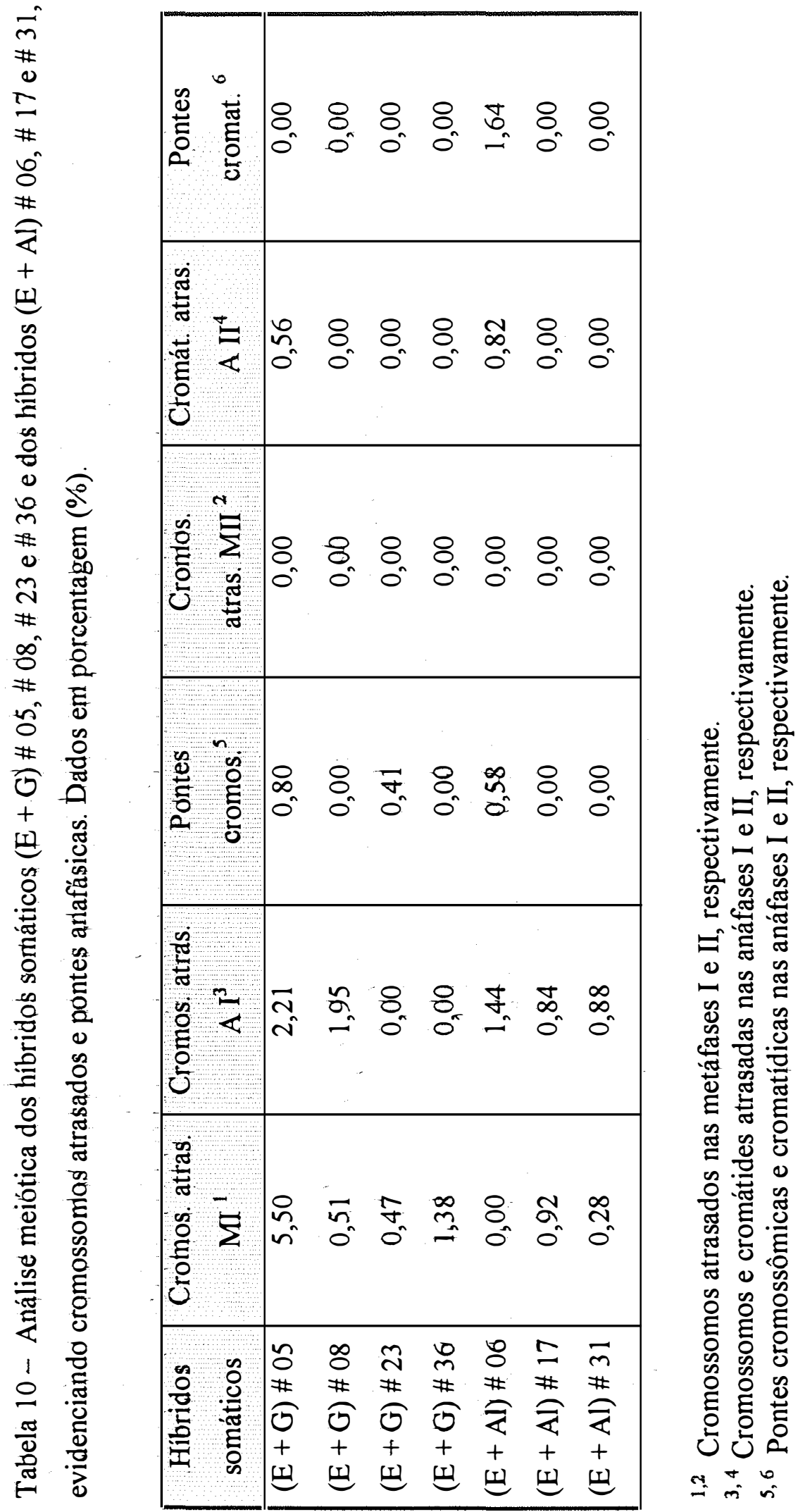




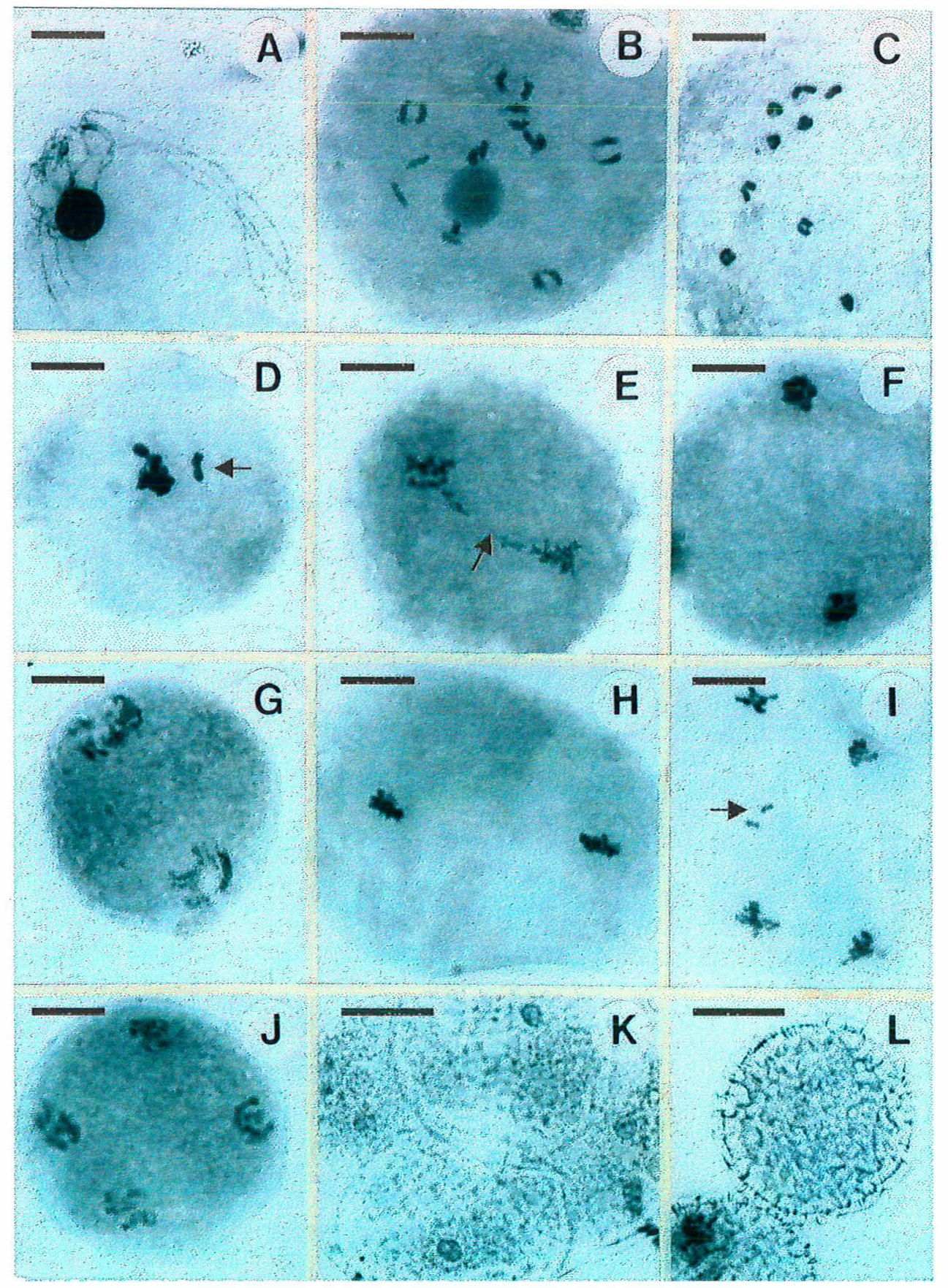

Figura 11 - Diferentes fases da meiose em $(E+G)$ \# 05. A. Paquíteno. B e C. Segregação de nove bivalentes. D. Presença de cromossomos atrasados em metáfase I (seta). E. Ponte cromossômica em anáfase I (seta). F. Telófase I. G. Prófase II. H. Metáfase II. I. Cromátide atrasada em anáfase II (seta). J.Telófase II. K. Tétrade. L. Grão de pólen. Barra $=10 \mu \mathrm{m}$. 


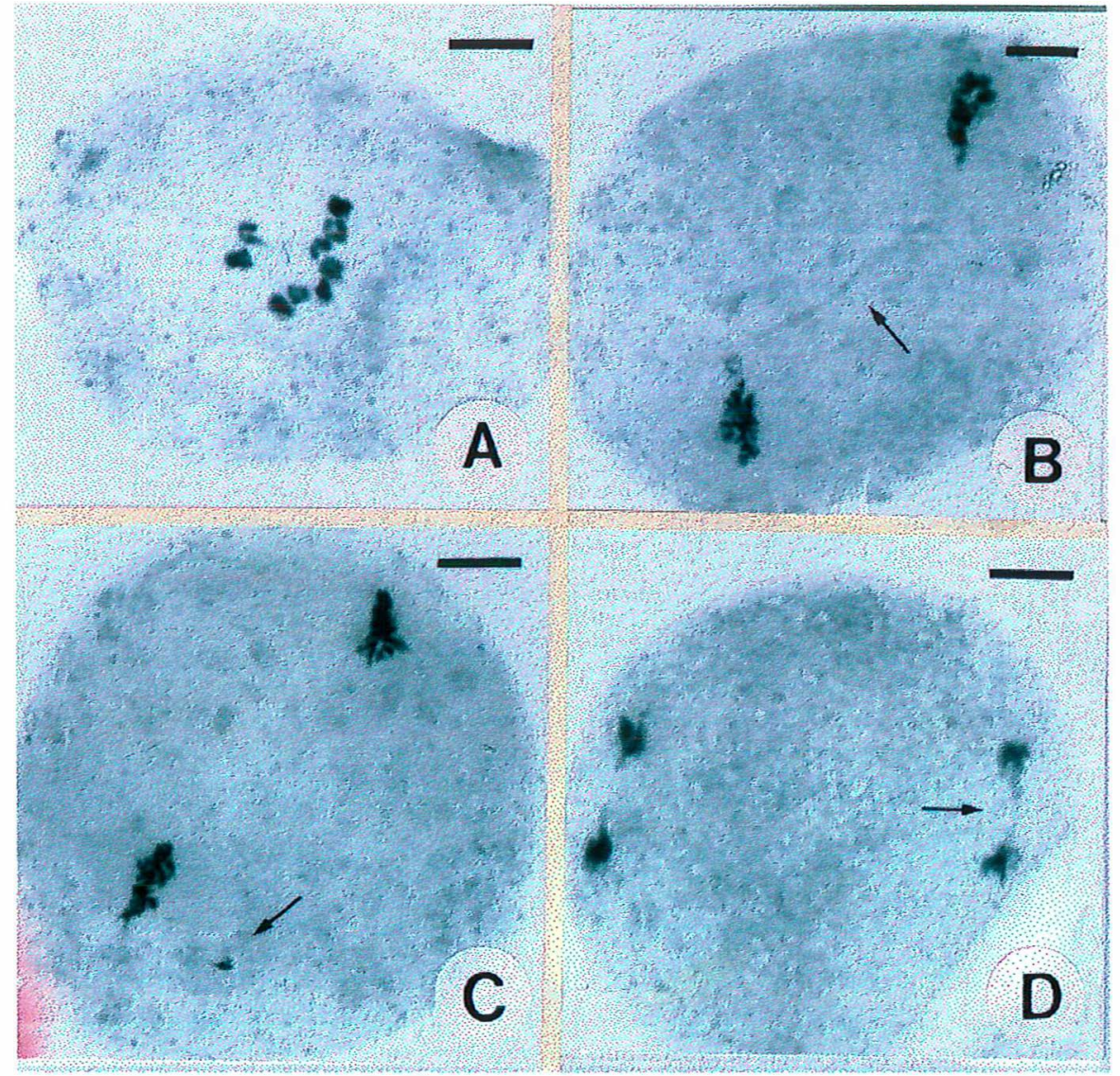

Figura 12 - Meiose em $(E+A l)$ \# 06. A. Segregação de 9 bivalentes. B. Ponte cromossômica (seta). C. Cromossomo atrasado (seta). D. Ponte cromatídica (seta). Barra $=10 \mu \mathrm{m}$. 
É de se supor, portanto, que ocorreu eliminação cromossômica preferencial de um dos lotes cromossômicos durante a fase de cultura 'in vitro'. Não se pode afirmar se essa eliminação ocorreu antes da regeneração de brotos ou posteriormente. O complemento eliminado foi provavelmente aquele correspondente à espécie cultivada, $P$. edulis Sims. f. flavicarpa, uma vez que em ambas situações, as plantas híbridas em muito se assemelham aos parentais $P$. giberti e $P$. alata. Devido à essa eliminação cromossômica, esses materiais possivelmente são cíbridos, isto é, possuem o núcleo da espécie selvagem e o genoma citoplasmático de ambas as espécies.

Os híbridos apresentam-se bastante vigorosos, em consequência das interações dos genomas citoplasmáticos. Esta situação foi verificada nos híbridos $(\mathrm{E}+\mathrm{G})$ e $(\mathrm{E}+\mathrm{Al})$ em condições de campo, onde floresceram e produziram frutos com sementes viáveis durante os anos de 1995 a 1997 (dados não apresentados).

Uma alternativa para estudar sua natureza citoplasmática seria a análise comparativa dos padrões de restrição, usando sondas de DNA mitocondrial. Os cíbridos tendem a apresentar bandas de ambos os parentais. $\mathrm{O}$ vigor de $(E+G)$ e $(E+A l)$ pode estar associado à sua natureza híbrida.

Têm-se observado na literatura que, as plantas regeneradas de experimentos de fusão de protoplastos mostram um número variável de cromossomos (Lefrançois et al., 1993). Em Solanum, esse fenômeno é bastante comum (Austin et al., 1986; Puite et al., 1986; Williams et al., 1993), o qual já foi igualmente relatado em alguns híbridos sexuais (Davies, 1974), em poliplóides naturais (Nirmala \& Rao, 1984) sendo que, no gênero Hordeum foi observada essa eliminação preferencial de cromossomos de um dos parentais (Finch, 1983). 
Tabela 11 - Segregações meióticas nos híbridos somáticos $(E+G) \# 05$, \# 08, \# 23, \# 36, $(\mathrm{E}+\mathrm{Al}) \# 06, \# 17$ e \# 31 . Número de células analisadas $=30$.

\begin{tabular}{|c|c|}
\hline Híbridos somáticos & Segregação \\
\hline$(\mathrm{E}+\mathrm{G}) \# 05$ & 9 II \\
$(\mathrm{E}+\mathrm{G}) \# 08$ & 9 II \\
$(\mathrm{E}+\mathrm{G}) \# 23$ & 9 II \\
$(\mathrm{E}+\mathrm{G}) \# 36$ & 9 II \\
$(\mathrm{E}+\mathrm{Al}) \# 06$ & 9 II \\
$(\mathrm{E}+\mathrm{Al}) \# 17$ & 9 II \\
$(\mathrm{E}+\mathrm{Al}) \# 31$ & 9 II \\
\hline
\end{tabular}

Em híbridos somáticos, durante a fase de cultura de tecidos, a eliminação cromossômica é uma característica usual, principalmente durante a fase de regeneração de plantas (Pjinacker et al., 1987). Em células somáticas híbridas, os cromossomos de um dos parentais podem ser eliminados preferencialmente (Pental et al., 1987).

Ainda se tratando de híbridos somáticos, em brassicas a eliminação cromossômica é variável. É sugerido na literatura que essa variação ocorre devido à divergência genética e nível de ploidia das espécies parentais envolvidas no processo de fusão. Outra possível causa seria devido às diferenças na duração dos ciclos celulares dos parentais (Sundenberg \& Glimelius, 1991).

Gilissen et al. (1992) sugerem que a eliminação em híbridos somáticos ocorre devido às interações ao nível dos genomas citoplasmáticos e nucleares, relacionando-a com distâncias filogenéticas, tipo de explante, origem do tecido, estado metabólico, volume celular e, principalmente, com a duração do ciclo celular e nível de ploidia. Nos híbridos somáticos Solanum brevidens $+S$. 
tuberosum também se observou essa tendência, causada provavelmente por irregularidades mitóticas, como não-disjunção cromossômica (Willians et al., 1990).

\section{3 - Análise da viabilidade do grão de pólen}

Os dados da análise da viabilidade do grão de pólen (V) para as cinco espécies parentais e respectivos híbridos somáticos $(E+A m),(E+C),(E+$ $\mathrm{G})$ e $(\mathrm{E}+\mathrm{Al})$, bem como o teste $\mathbf{t}$ para comparação das viabilidades médias, estão apresentadas nas Tabelas 12, 13, 14 e 15, respectivamente. Em média, as espécies parentais apresentaram alta viabilidade do grão de pólen, todas elas acima de 90,0 \%. Já para os híbridos somáticos, estes valores foram variados, porém foram igualmente observados valores acima de $70,0 \%$.

Nos híbridos $(E+A m)$, apenas o \# 35 apresentou um valor menor (72,90 \%) (Tabela 12). Isto já era esperado, uma vez que essa planta foi a que apresentou uma maior porcentagem de irregularidades meióticas (Tabela 5). Para os outros híbridos, foram encontrados valores acima de 80,0\% (Figura 13).

Nos híbridos $(E+C)$, não existem diferenças significativas entre os valores médios de viabilidade polínica, demostrada pelo teste t (Tabela 13). Pela Tabela 7, pode-se observar que ambos os híbridos apresentam meiose irregular. 


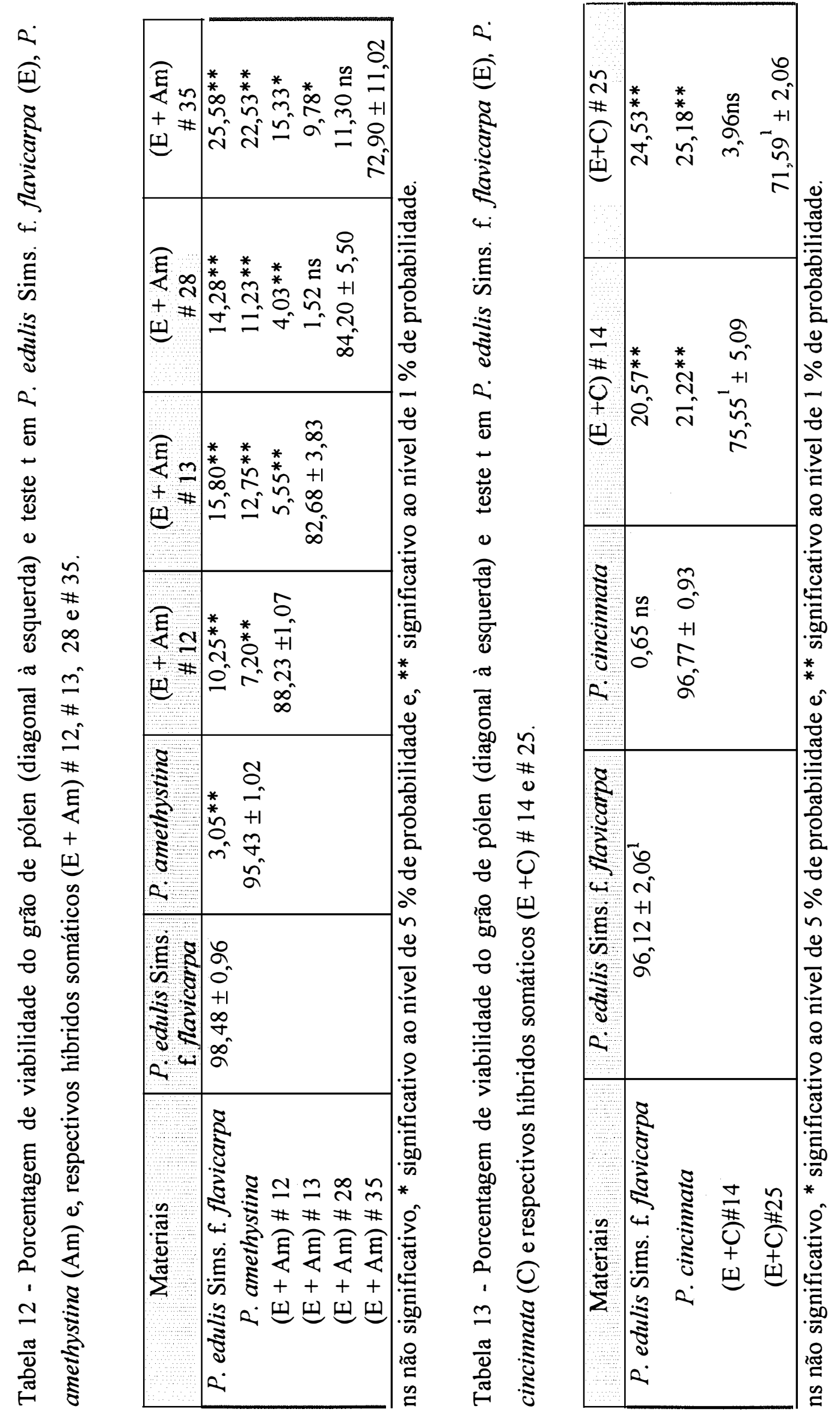



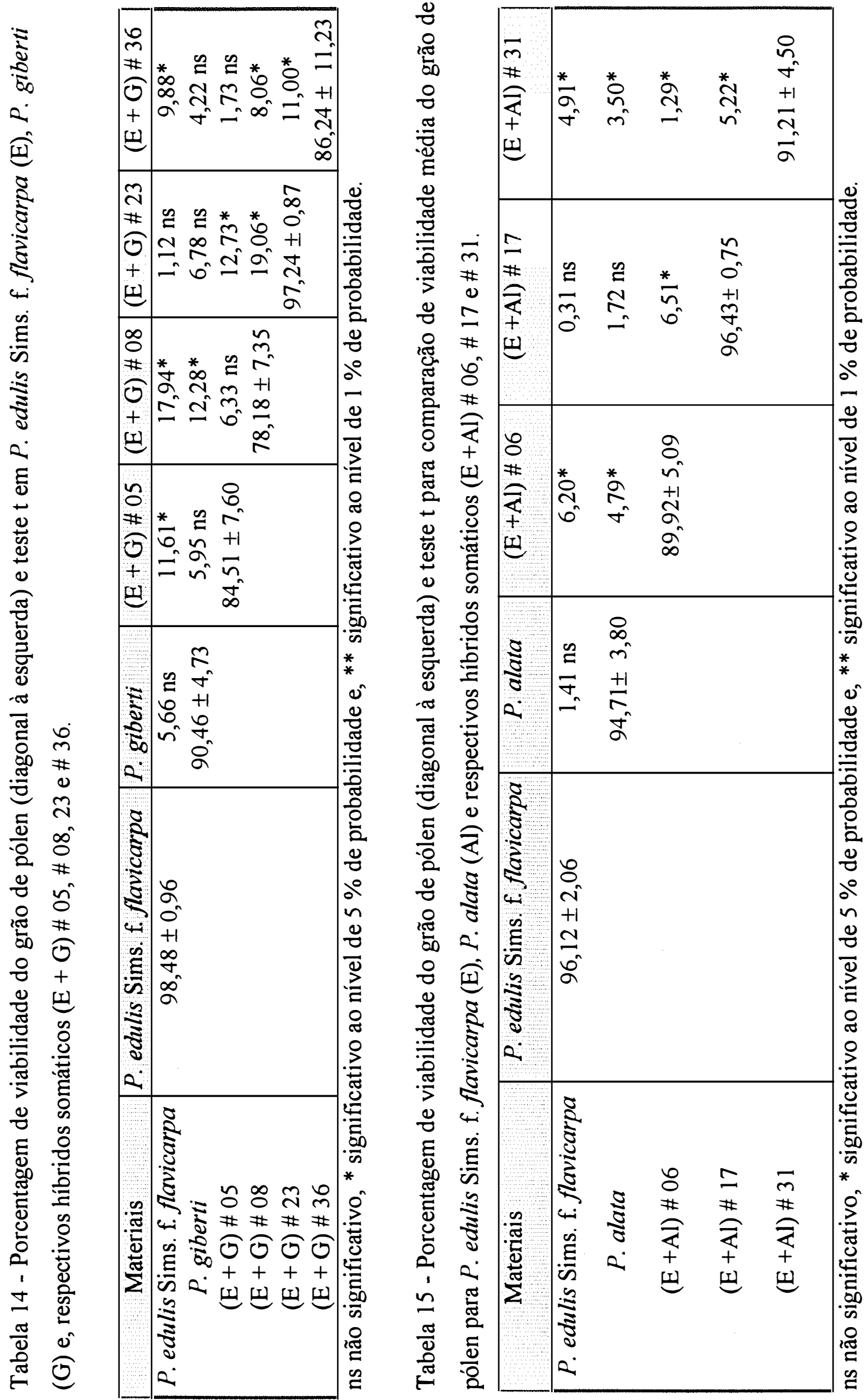

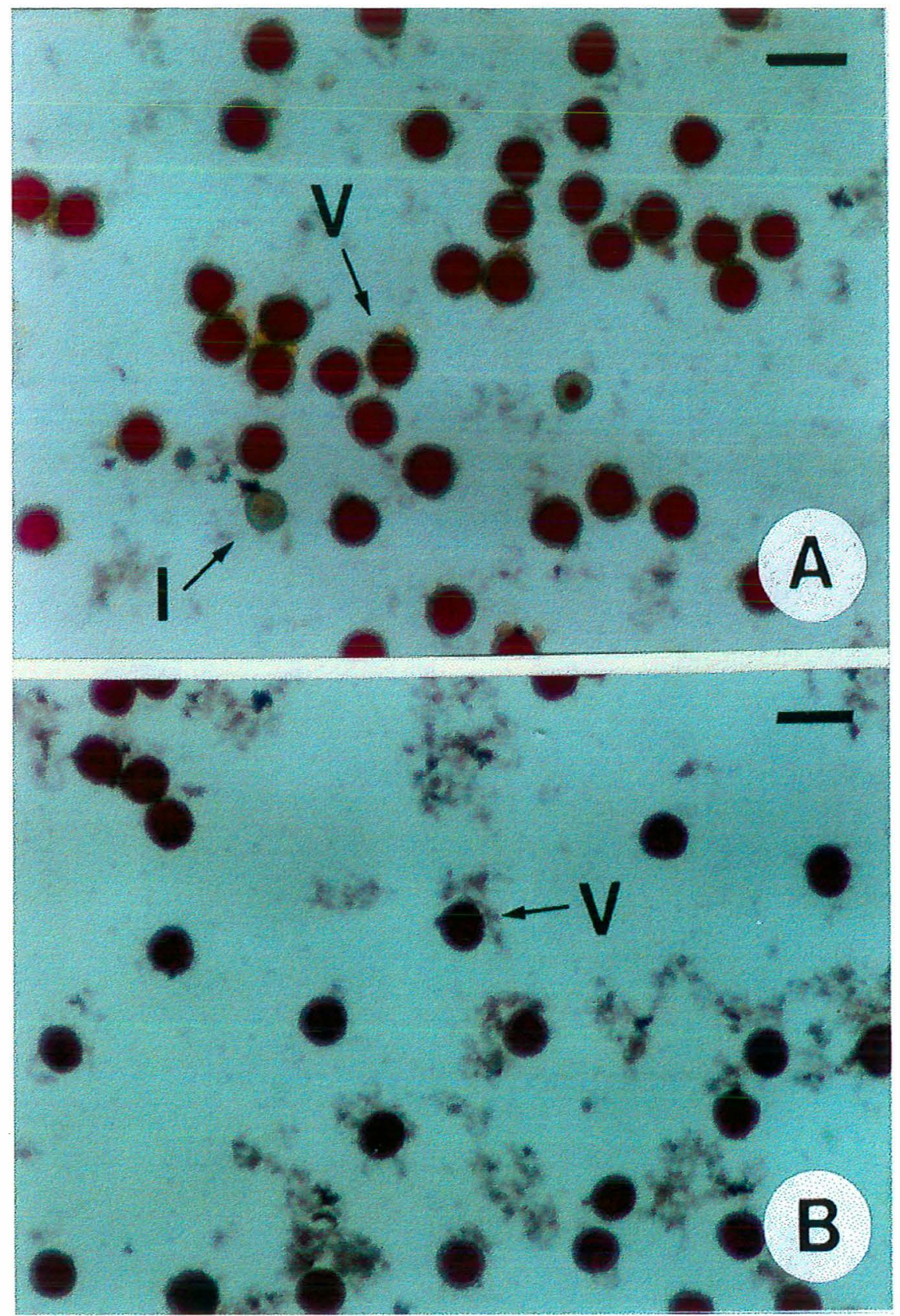

Figura 13 - A e B. Viabilidade do grão de pólen em $(E+A m)$ \# 13 e \# 28, respectivamente. V. Grão de pólen viável.

I. Grão de pólen inviável. Barra $=100 \mu \mathrm{m}$. 
Com o intuito de avaliar o efeito das irregularidades meióticas sobre a viabilidade do grão de pólen nos híbridos $(E+A m)$ e $(E+C)$, foi estudada a correlação entre os valores de viabilidades $x$ irregularidades presentes em cada fase da meiose. Em todas as fases, os valores de correlação foram altos e negativos, indicando que, quanto maior as irregularidades meióticas, menores valores de viabilidade polínica são esperados (Figuras 14 e 15, respectivamente). Para os híbridos $(E+G)$ e $(E+A l)$ não foi estudada a correlação, uma vez que esses apresentaram uma meiose regular, com poucas irregularidades meióticas e viabilidades polínicas elevadas.

Muitos híbridos somáticos obtidos por fusão de protoplastos entre espécies sexualmente incompatíveis têm mostrado uma grande variação em termos de fertilidade, variando desde férteis até completamente estéreis. Yamagishi et al. (1994) observou uma elevada viabilidade polínica entre híbridos Brassica oleracea + B. campestris (em média, 88,0 \%). Em Petunia, Taguchi et al (1993) encontraram uma viabilidade de $34,0 \%$, no entanto, apesar desse baixo valor, foram obtidas progênies $F_{2}$ e um retrocruzamento.

No gênero Solanum, o que se nota é que os híbridos somáticos mostram uma variação com relação à porcentagem de grãos de pólen viáveis.

Conicella et al. (1997) estudando hibridos somáticos entre $S$. commersonii e $S$. tuberosum, observaram um alto grau de esterilidade, sendo essa esterilidade reflexo das anormalidade s cromossômicas. O mesmo comportamento foi visto em híbridos S. tuberosum $+S$. circaeifolum. Em condições de campo, esses híbridos floresceram, porém se apresentaram praticamente macho-estéreis. 

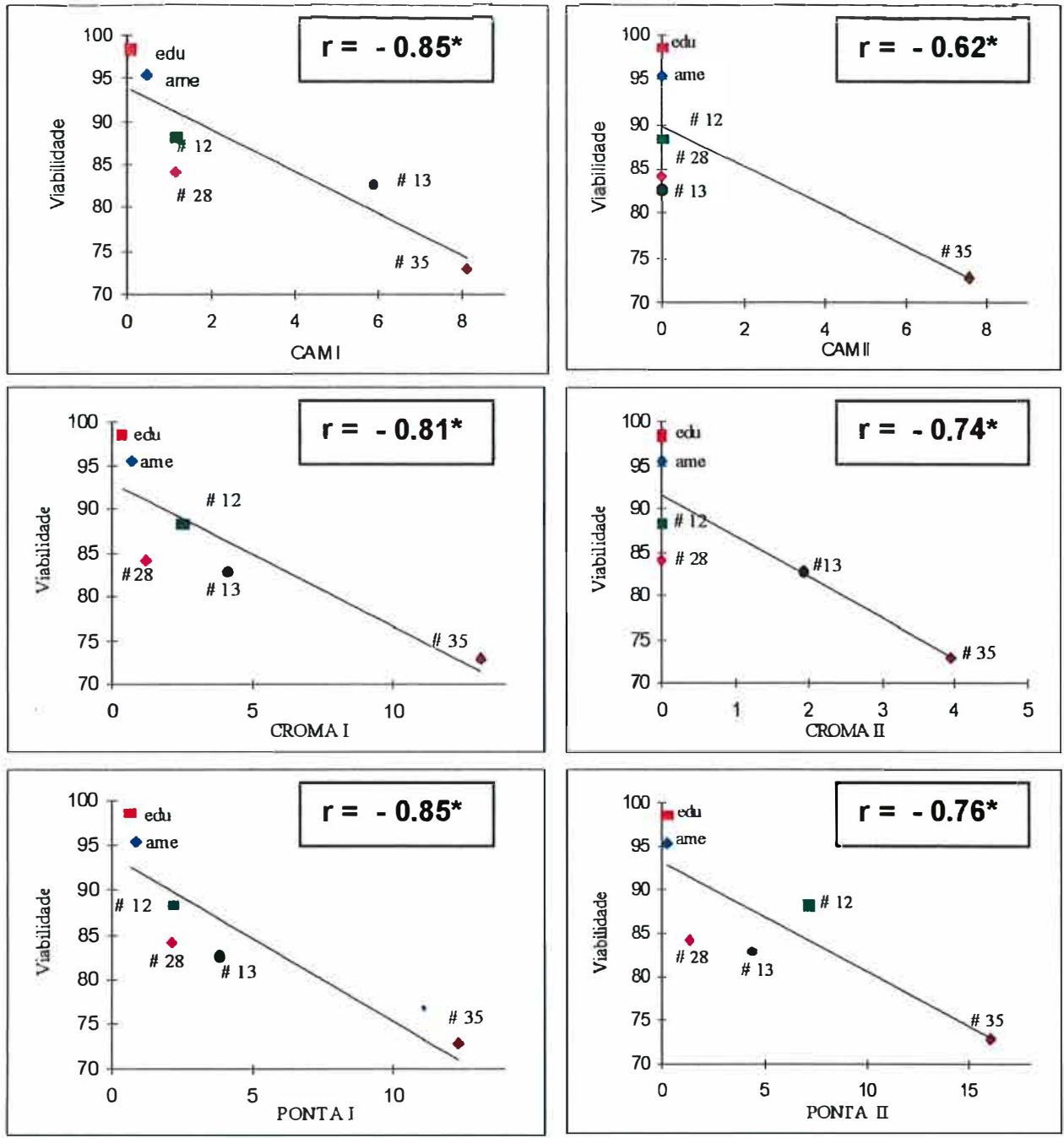

CAM I e CAM II, cromossomos atrasados em metáfase I e anáfase I, respectivamente;

CROMA I e CROMA II, cromátides atrasadas em metáfase II e anáfase II, respectivamente; PONTA I e PONTA II, pontes cromossômicas e cromatídicas, respectivamente;

* significativo ao nível de $5 \%$ de probabilidade.

Figura 14 - Correlações (r) entre viabilidade média do grão de pólen e irregularidades meióticas observadas em P. edulis Sims. f. flavicarpa (edu), P. amethystina (ame) e respectivos híbridos somáticos $(\mathrm{E}+\mathrm{Am}) \# 12$, \# 13, \# 28 e \# 35. 

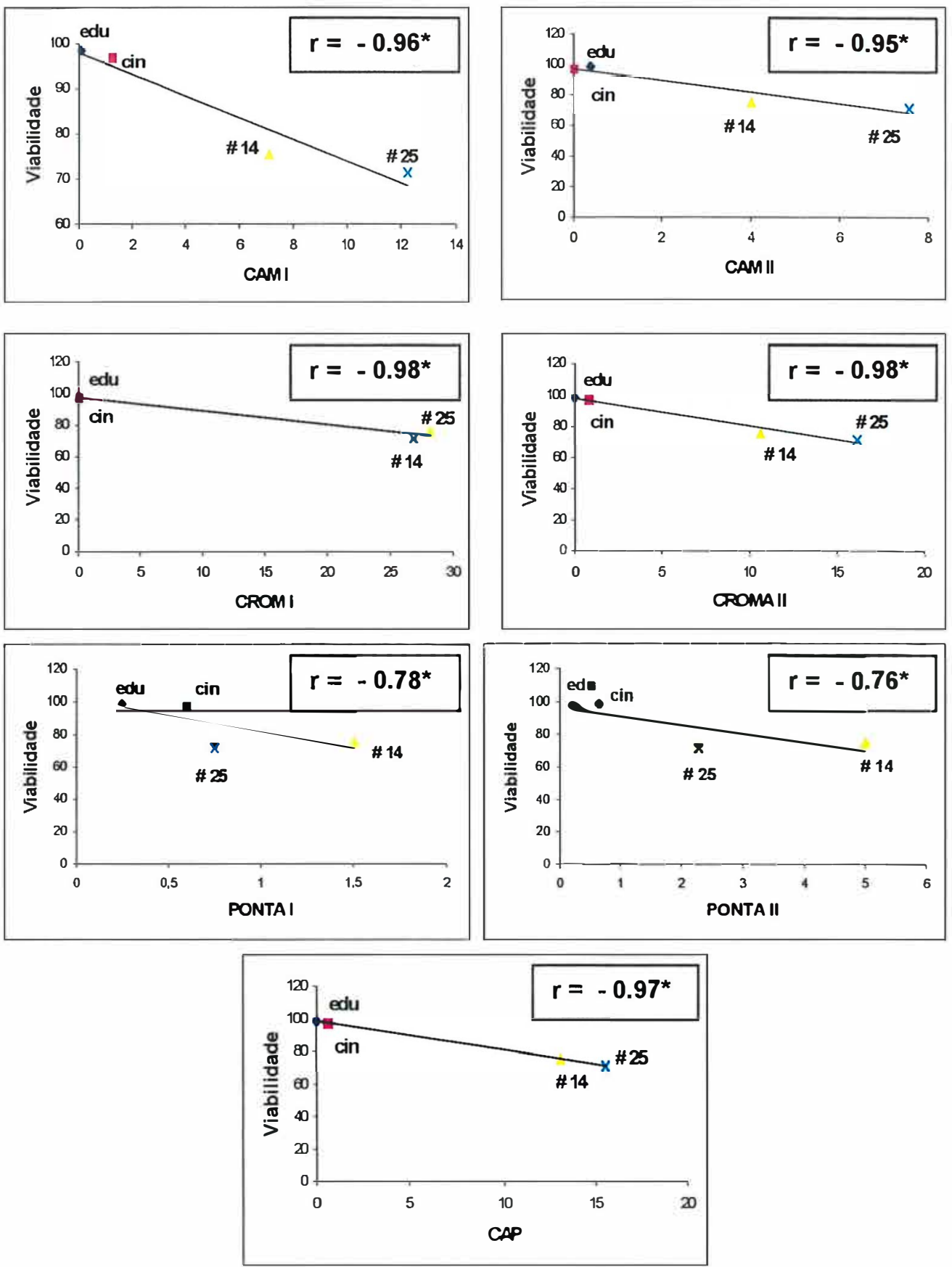

CAM I e CAM II, cromossomos atrasados em metáfase I e anáfase I, respectivamente;

CROMA I e CROMA II, cromátides atrasadas em metáfase II e anáfase II, respectivamente;

PONTA I e PONTA II, pontes cromossômicas e cromatídicas, respectivamente;

* significativo ao nível de $5 \%$ de probabilidade.

Figura 15 - Correlações (r) entre viabilidade média do grão de pólen e irregularidades meióticas observadas em $P$. edulis Sims. f. flavicarpa (edu), P. cincinnata (cin) e respectivos híbridos somáticos $(\mathrm{E}+\mathrm{C})$ \# 14 e \# 25. 
Neste estudo pôde-se notar que, apesar da ocorrência de irregularidades meióticas, ocorreu um mínimo de $70,0 \%$ de viabilidade do grão de pólen em todas as plantas híbridas analisadas. Nos híbridos $(E+A m)$ e $(E+$ C), além desses valores, que podem ser considerados altos (Tabelas 12 e 13), ocorreu uma frequência de pareamento multivalente (Tabelas 6 e 8). Isso indica que, esses híbridos, podem ser utilizados no melhoramento genético do maracujazeiro visando a introgressão de genes para resistência a doenças. Devese lembrar que, os requisitos básicos para o sucesso das técnicas de hibridação somática, são a ocorrência de pareamento homeólogo, possibilitando a recombinação e a elevada viabilidade do grão de pólen. Desta forma, é possível obter-se retrocruzamentos, progênies segregantes, o que é essencial para a continuidade de um programa de melhoramento genético.

\section{4 - Efeito da poliploidia nas células da epiderme foliar dos híbridos somáticos}

O teste Tukey para comparação da área média das células guardas dos estômatos e número médio de estômatos para médias para os materiais dos grupos 2 e 3, estão apresentados nas Tabelas 16 e 17.

Observa-se que a espécie $P$. edulis Sims. f. flavicarpa possue área menor de estômatos quando comparada à $P$. amethystina, porém, apresenta um maior número médio de estômatos. Já os híbridos somáticos possuem uma maior área que os parentais diplóides, no entanto mostra um menor número médio de estômatos por campo. Nenhuma diferença com relação à área e número médio de estômatos foi observada entre os híbridos somáticos, ou seja, para essas características, os híbridos são estatisticamente iguais (Tabela 16). 
Tabela 16 - Teste Tukey para comparação de médias da área $\left(\mu \mathrm{m}^{2}\right)$ e número de estômatos entre diplóides, $P$. edulis Sims. f. flavicarpa e P. amethystina, e poliplóides (E + Am) \# 12, \# 13,\# 28 e \# 35.

\begin{tabular}{|c|c|c|c|c|}
\hline \multicolumn{3}{|c|}{ Area de estômatos* } & \multirow{2}{*}{\multicolumn{2}{|c|}{$\frac{\text { Número de estômatos* }}{7,02 \pm 0,29 \mathrm{a}}$}} \\
\hline P. edulis Sims. f. flavicarpa & $20,40 \pm 0,72 a$ & & & \\
\hline P. amethystina & $22,04 \pm 1,44$ & b & $5,04 \pm 0,62 b$ & \\
\hline$(E+A m) \# 12$ & $23,94 \pm 0,68$ & $\mathrm{c}$ & $4,14 \pm 1,55$ & c \\
\hline$(E+A m) \# 13$ & $24,13 \pm 2,66$ & c & $4,33 \pm 0,72$ & c \\
\hline$(E+A m) \# 28$ & $24,25 \pm 2,55$ & c & $4,67 \pm 1,65$ & c \\
\hline$(E+A m) \# 35$ & $24,89 \pm 1,72$ & c & $5,01 \pm 2,31$ & c \\
\hline
\end{tabular}

* Médias seguidas de mesma letra não diferem estatisticamente ao nível de $5 \%$ de probabilidade.

Na Tabela 17 observa-se que, para os materias do grupo genotípico 3 , o teste Tukey mostrou que a espécie $P$. edulis Sims. f. flavicarpa possue área menor de estômatos quando comparada à $P$. cincinnata e apresenta um maior número médio de estômatos.

Tabela 17 - Teste Tukey para comparação de médias da área $\left(\mu \mathrm{m}^{2}\right)$ e número de estômatos entre diplóides, $P$. edulis Sims f. flovicarpa e P. cincinnata, e poliplóides (E + C) \# 14 e \#25.

\begin{tabular}{|llllll|}
\hline \multicolumn{3}{|c}{ Área de estômatos } & \multicolumn{3}{c|}{ Número de estômatos } \\
\hline P. edulis Sims. f. flavicarpa & $20,40 \pm 0,72$ & a & $7,02 \pm 0,29$ & a & \\
P. cincinnata & $21,05 \pm 1,44$ & b & $6,64 \pm 1,55$ & b \\
$($ E + C) \# 14 & $25,39 \pm 0,68$ & c & $4,92 \pm 0,76$ & c \\
$($ E + C) \#25 & $24,23 \pm 0,68$ & c & $5,01 \pm 1,33$ & c \\
\hline
\end{tabular}

* Médias seguidas de mesma letra não diferem estatisticamente ao nível de $5 \%$ de probabilidade. 


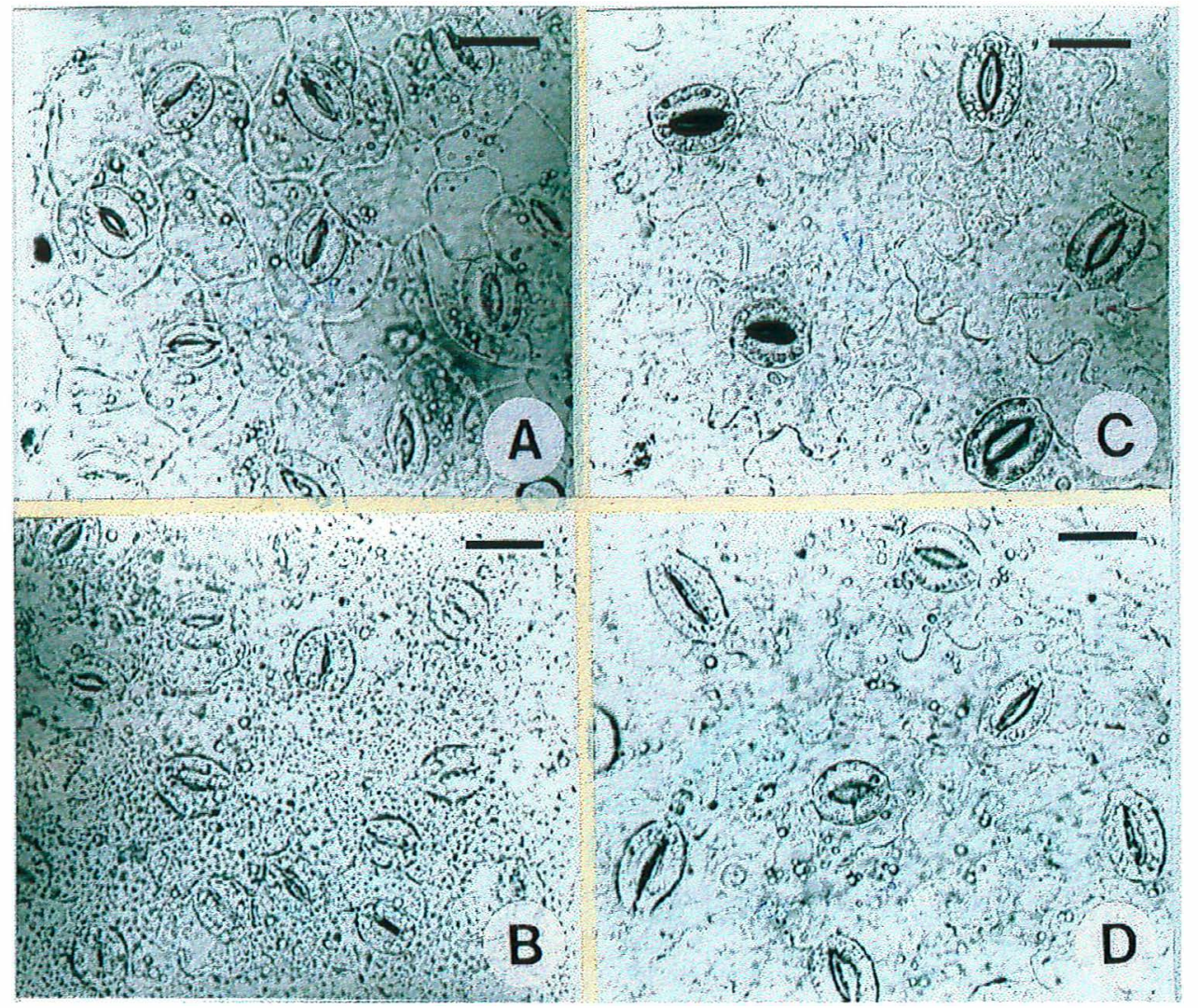

Figura 16 - Aspecto geral das células guarda de estômatos. A. P. edulis Sims. f. flavicarpa. B. P. cincinnata. C. $(\mathrm{E}+\mathrm{C}) \# 14$ e, D. $(\mathrm{E}+\mathrm{C}) \# 25$. Barra $=30 \mu \mathrm{m}$. 
Neste grupo, os híbridos somáticos possuem uma maior área que que os parentais diplóides, no entanto apresentam um menor número médio de estômatos por campo (Tabela 17 e Figura 16). Os resultados observados nas Tabelas 16 e 17 já eram esperados, uma vez que os híbridos somáticos $(E+A m)$ e $(E+C)$ são de natureza tetraplóide. Assim, pode-se afirmar que, à medida que ocorre um incremento no nível de ploidia nas plantas, é de se esperar que essas apresentem uma maior área e menor número médio de estômatos por campo visual.

Os dados referentes ao teste Tukey dos híbridos $(E+G)$ e $(E+A l)$ estão apresentados nas Tabelas 18 e 19. Interessante verificar que, para todos os híbridos, não existem diferenças significativas para essas duas características, ou seja, essas plantas possuem mesma área e número médio de estômatos que as espécies parentais. Esses resultados também eram esperados, uma vez que todos os híbridos $(E+G)$ e $(E+A l)$ apresentaram $2 n=2 x=18$.

Tabela 18 - Teste Tukey para comparação de médias da área $\left(\mu \mathrm{m}^{2}\right)$ e número de estômatos entre diplóides $P$. edulis Sims. f. flavicarpa, P. giberti, e poliplóides $(\mathrm{E}+\mathrm{G})$ \# 05, \# 08, \# 28 e \# 36.

\begin{tabular}{|lllc|}
\hline \multicolumn{2}{c}{ Área de estômatos } & Número de estômatos \\
\hline P. edulis Sims. f. flavicarpa & $20,40 \pm 0,72$ a & $7,02 \pm 0,29$ a \\
P. giberti & $19,30 \pm 0,63$ a & $6,98 \pm 0,60$ a \\
$(\mathrm{E}+\mathrm{G}) \# 05$ & $20,46 \pm 0,93 \quad$ a & $6,88 \pm 0,81$ a \\
$(\mathrm{E}+\mathrm{G}) \# 08$ & $20,33 \pm 1,98 \quad \mathrm{a}$ & $7,33 \pm 1,78 \quad \mathrm{a}$ \\
$(\mathrm{E}+\mathrm{G}) \# 23$ & $22,09 \pm 3,57 \quad \mathrm{a}$ & $6,02 \pm 1,03 \quad \mathrm{a}$ \\
$(\mathrm{E}+\mathrm{G}) \# 36$ & $21,78 \pm 1,72 \quad \mathrm{a}$ & $6,78 \pm 0,72 \quad$ a \\
\hline
\end{tabular}

* Médias seguidas de mesma letra não diferem estatisticamente ao nível de $5 \%$ de probabilidade. 
Tabela 19 - Teste Tukey para comparação de médias da área $\left(\mu \mathrm{m}^{2}\right)$ e número de estômatos entre diplóides $P$. edulis Sims. f. flavicarpa, P. alata, e poliplóides (E + Al) \# 06 . \# 17 e \# 31.

\begin{tabular}{|c|c|c|c|}
\hline Area de est & matos & 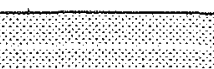 & Número de estómatos \\
\hline P. edulis Sims. f. flavicarpa & $20,40 \pm 0,72$ & $\mathrm{a}$ & $7,02 \pm 0,29 \quad a$ \\
\hline P. alata & $20,45 \pm 0,47$ & $\mathrm{a}$ & $6,46 \pm 0,78 \quad a$ \\
\hline$(\mathrm{E}+\mathrm{Al} \# 06$ & $19,37 \pm 0,89$ & $\mathrm{a}$ & $6,89 \pm 0,33 \quad a$ \\
\hline$(E+A l) \# 17$ & $20,42 \pm 0,97$ & $\mathrm{a}$ & $6,77 \pm 0,27 \quad a$ \\
\hline$(\mathrm{E}+\mathrm{Al}) \# 31$ & $20,83 \pm 0,87$ & $\mathrm{a}$ & $6,62 \pm 0,44 a$ \\
\hline
\end{tabular}

* Médias seguidas de mesma letra não diferem estatisticamente ao nível de $5 \%$ de probabilidade.

Essas análises demonstram que os níveis de ploidia em plantas podem ser, indiretamente, determinados utilizando dessas características, já que elas são correlacionadas.

Dessa forma, pode-se inferir que as plantas pertencentes aos grupos 4 e $5(E+G)$ e $(E+A l)$, respectivamente são semellhantes aos parentais diplóides, além de apresentarem comportamento meiótico normal com elevada viabilidade do grão de pólen. Esses resultados nos leva a crer que, nessas plantas, ocorreu de fato eliminação cromossômica do lote oriundo do parental cultivado, fenômeno comum em se tratando de híbridos somáticos. 


\section{5 - CONCLUSÕES}

A partir dos resultados obtidos neste trabalho, pôde-se concluir que:

1 - Ocorre variação nas características morfológicas dos híbridos somáticos de Passiflora spp. e por isso, tais características não devem ser consideradas de valor diagnóstico para a sua identificação.

2 - Os híbridos somáticos $(E+A m)$ e $(E+C)$ apresentam $2 n=4 x=36$ cromossomos, com meiose irregular, presença de cromossomos atrasados e/ou com ascensão precoce, pontes cromossômicas e cromatídicas. Também apresentam pareamento homeólogo, com configurações dos tipos univalentes, bivalentes e tetravalentes e, elevados valores de viabilidade do grão de pólen.

3 - Nos híbridos $(E+G)$ e $(E+A l)$ ocorreu eliminação cromossômica do lote oriundo do parental cultivado, uma vez que apresentam $2 n=2 x=18$ cromossomos e se comportam de maneira semelhante aos parentais diplóides selvagens, no que diz respeito ao seu comportamento vegetativo e reprodutivo.

4 - Existe uma elevada correlação negativa entre os valores de viabilidade do grão de pólen e irregularidades meióticas. Quanto mais irregular for a meiose, menores valores médios de viabilidade do grão de pólen são observados. 
5 - Existe uma elevada correlação negativa no que diz respeito à área $\mathrm{e}$ número médio de estômatos/campo visual do microscópio ótico, ou seja, os poliplóides possuem maior área e menor número de estômatos/campo visual do microscópio ótico. 


\section{REFERÊNCIAS BIBLIOGRÁFICAS}

ALEXANDER, M..P. A versatile stain for pollen from fungi, yeast ad bacteria. Stain Technology, v.55, p.13-18, 1980.

ALLARD, R. W. Princípios de melhoramento genético de plantas. Rio de Janeiro: Edgard Blucher, 1971. 381p.

AUSTIN, S.; EHLENFELDT, M. K.; BAER, M.A.; HELGESON, J.P. Somatic hybrids produced by protoplast fusion between $S$. tuberosum and $S$. brevidens: phenotipic variation under field conditions. Theoretical and Applied Genetics, v.71, p.682690, 1986.

BABIYCHUK, E.; KUSHNIR, S.; GLEBA, Y. Y. Spontaneous extensive chromosome elimination in somatic hybrids between somatically congruent species Nicotiana tabacum L. and Atropa belladonna L. Theoretical and Applied Genetics, v.84, p.87-91, 1992.

BARBOSA, L. S. Resistência de Passiflora spp a Xanthomonas campestris pv. passiflorae e deteç̧ão do patógeno em sementes. Viçosa, 1995. 66p. (Tese Doutorado) - Universidade Federal de Viçosa.

BARBOSA, L. V.; VIEIRA, M. L. C. Meiotic behavior of passion fruit somatic hybrids, Passiflora edulis f. flavicarpa Degener + P. amethystina Mikan. Euphytica, v.98, p. 121-127, 1997. 
BEGUM, F.; PAUL, S.; BAG, N.; SIKDAR, S. R.; SEM, S. K. Somatic hybrids between Brassica juncea (L). Czern. And Diplotaxis harra (Forsk.) Boiss and the generation of backcross progenies. Theoretical and Applied Genetics, v.91, p.1167-1172, 1995.

BINDING, H.; NEHLS, R.; JORGENSEN, J. Protoplast regeneration in higher plants. In: FUGIWARA, A., (Ed). Plant tissue culture. Tokyo: Japanese Association for Plant Tissue Culture, 1982. p.575-578.

BORGES, F. Tamano y densidad de estomas en clones cultivados y especies selvagens de Musa. Agronomical Tropical (Venezuela), v.21, p.139-143, 1971.

BRUCKNER, C. H. Auto incompatibilidade no maracujá (Passiflora edulis. Sims). Viçosa, 1994. 85p (Tese Doutorado). Universidade Federal de Viçosa.

CARLSON, P. S.; SMITH, H. H.; DEARING, R. D. Parasexual interspecific plant hybridization. Proceeding National Academic Science U.S.A., v.69, p.2292-2294, 1972.

CHAGAS, C. M. Doenças viróticas e similares do maracujazeiro no Brasil. In: RUGGIERO, C. (Coord.). A cultura do maracujá no Brasil. Jaboticabal: FUNEP, 1991. p. 175-186.

CHEVRE, A.M.; EBER, F.; MARGALE, E.; KERLAN, M.C. Comparision of somatic and sexual Brassica napus - Sinapis alba hybrids and their progeny by cytogentic studies and molecular characterization. Génome, v.37, p.376-374, 1994. 
CHIANG, M. S.; CHIANG, B. Y.; GRANT, W. F.; Transfer of resistance to race 2 of Plasmodiophora brassicae from Brassica napus to cabbage (B. oleracea var. capitata). II - Meiosis in the interspecific hybrids between B. napus and $2 \mathrm{x}$ and $4 \mathrm{x}$ cabagge. Euphytica, v.27, p.81-93, 1978.

COCKING, E. C. A method for the isolation of plant protoplasts and vacuoles. Nature, v.187, p.927-929, 1960.

CONICELLA, C.; GENVALDO, G.; LUCIA, R.; RAMULU, K.S.; CARDI, T. Tapetal degeneration and meiotic defects are invoved in the male sterility of Solanum commersonii $(+)$ S. tuberosum somatic hybrids. Theoretical and Applied Genetics, v.95, p.609-617, 1997.

CUNADO, N.; CALLEJAS, S.; GARCIA, M. J.; FERNANDEZ, A.; SANTOS, J. L. Chromosome pairing in the allotetraploid Aegilops biuncialis and a triploid intergeneric hybrid. Génome, v.36, p.664-670, 1996.

DAVIES, A.; JENKINS, G.; REES, H. Diploidisation of Lotus corniculatus L. (Fabaceae) by elimination of multivalents. Chromosoma, v.99, p.289-295, 1990.

DIAS, S. C.; TAKATSU, A. Translocação de Xanthomonas campestris f. passiflorae nos tecidos da hospedeira e sua deteç̧ão na semente. Fitopatologia Brasileira, v.15, n.2, p.131, 1990.

DORNELAS, M. C. Cultura e fusão de protoplastos de Passiflora spp. Piracicaba, 1995. 182p. Dissertação (M.S.) - Escola Superior de Agricultura "Luiz de Queiroz", Universidade de São Paulo. 
DORNELAS, M. C.; TAVARES, F. C. A.; OLIVEIRA, J.C.; VIEIRA, M. L. C. Plant regeneration from protoplast fusion in Passiflora spp. Plant Cell Reports, v.15, p.106-110, 1995.

DVORAK, J. Evidence for genetic suppression of heterogenetic chromosome pairing in poliploid species of Solanum, Aect Petota. Canadian Journal of Genetics and Cytology, v.25, p.530-539, 1983.

Empresa Brasileira de Pesquisa Agropecuária - Reunião Técnica: Pesquisa em maracujazeiro no Brasil. Cruz das Almas (BA): CNPMF, 1998 (Documento, 77).

FAHLESON, J., ERIKSON, I.; LANDGREN, M.; GLIMELIUS, K. Intertribal somatic hybrids between Brassica napus and Thlapsi perfoliatum with high content of the $T$. perfoliatum specific nervonic acid. Theoretical Applied Genetics, v.87, p.795804, 1994.

FNP - Consultoria e comércio. Maracujá. In: Agrianual 96; Anuário estatístico da agricultura brasileira. São Paulo, 1996.p.285-291.

FRUPEX - EMBRAPA. Maracujá para exportação. Aspectos técnicos da produção. Brasília, 1996. 64p.

FUNGARO, M.H.P.; VIEIRA, M.L.C. Protoplastos de plantas: isolamento e regeneração. Ciência e Cultura, v.41, p.1151-1159, 1989.

GILISSEN, L.J.W.; VAN STAVEREN, M.J.; VERHOEVEN, H.A.; SREE RAMULU, K. Somatic hybridization between potato and Nicotiana plumbaginifolia. 1 Spontaneous biparental chromosome elimination and production of asymmetric hybrids. Theoretical and Applied Genetics, v.84, p.73-80, 1992. 
GLIMELIUS, C., FAHILESSON, J.; LANDGREN, M.; SJODIN, C.; SUNDBERG, E. Gene transfer via somatic hybridization in plants. Treends in Biotechnology, v.9, p.24-30, 1991.

GREECK, N.M.; REIJKENBERG, F.H.J. Laboratory and field evaluation of the performance of Passiflora caerullea as a rootstock tolerant to certain fungal root pathogens. Journal of Horticultural Science, v.66, n.6, p.725-729, 1991.

GROSSER, J.W.; MOURAO-FAO, F.A.A.; GMITTER Junior., F.G.; LOUZADA, E.S.; JIANG, J.; BAERGEN, K.; QUIROS, A.; CABASSON, C.; SCHELL, J.; CHANDLER, J.L. Allotetraploid hybrids between citrus and seven related genera produced by somatic hybridization. Theoretical and Applied Genetics, v.92, p.577-582, 1996.

HANSEN, L.N.; EARLE, E.D. Somatic hybrids between Brassica oleracea L. and Sinapis alba L. with resistance to Alternaria brassicae (Berk.) Sacc. Theoretical and Applied Genetics, v.94, p.1078-1085, 1997.

HARLAN, J.R. Evaluation of wild relatives of crop plants. FAO/UNEP/IBPGR. Technical Conference on Crop Genetic Resources, Rome. p.6-10, 1981.

IBGE, 1993. Produção agrícola municipal. Rio de Janeiro, p.53 (Intituto Brasileiro de Geografia e Estatística, Anuário Estatístico de Brasil).

ISLAM, A. K.M.R.; SHEPERD, K.W. Production of wheath-barley recombinant chromosomes through induced homoeologous pairing. 1 - Isolation of recombinant involving barley arms $3 \mathrm{HL}$ and $6 \mathrm{HL}$. Theoretical and Applied Genetics, v.83, p.489-494, 1992. 
JACOBSEN, E.; REINHOUT, P.; BERGERVOET, J. E. M.; LOOFF, J.; ABIDIN, P. E.; HUIGEN, D. J.; RAMANNA, M. S. Isolation and characterization of potatotomato somatic hybrids using an amylose-free potato mutant as parental genotype. Theoretical and Applied Genetics, v.85, p.159-164, 1992.

JONG, J.H.; WOLTERS, A.M.; KO, J. M.; VERHAAR, H.; VAN EDEN, J. Chromosome pairing and potential for intergeneric recombination in some hypotetraploid somatic hybrids of Lycopersicon esculentum (+) Solanun tuberosum. Génome, v.36, p.1032-1041, 1993.

KILLIP, E.P. The American species of Passifloraceae. Publications of The Field Museum of Natural History. Botanical Series, Chicago. v.19, p.1-613, 1938.

KISAKA, H.; KAMEYA, T. Production of somatic hybrids between Daucus carota L. and Nicotiana tabacum. Theoretical and Applied Genetics, v.88, p.75-80, 1994.

KNIGHT Junior., R.J. Development of tetraploid hybrid passion fruit clones with potential for north temperate zone. HortScience, v.26, n.12, p.1541-1543, 1991.

KNIGHT, J.R.; WINTERS, H.F. Pollination and fruit set of yellow passion fruit in Southern Florida. Proceedings of the Florida State Horticultural Society, v. 75, p.412-418, 1962.

LAWRENCE, W.J.C. Melhoramento genético vegetal. São Paulo: Editora da Universidade de São Paulo, 1980. 75p. 
LEFOL, E.; SÉGUIN-SWARTZ, G.; DOWNEY, R.K. Sexual hybridisation in croses of cultivated Brassica species with the crucifers Erucastrum gallirium and Raphanus raphanistrum: Potential for gene introgression. Euphytica, v.92, p.127-139, 1997.

LEFRANÇOIS, C.; CHUPEAU, J.P.; BOURGIN, J.P. Sexual and somatic hybridization in the genus Lycopersicon. Theoretical and Applied Genetics, v.86, p.533-546, 1993.

LOUZADA, E.S., GROSSER, J.W.; GMTTTER JUNIOR, F.G.; NIELSEN, B.; CHANDLER, J.L. Eigth new somatic hybrid citrus rootsocks with potential for improved disease resistance. HortScience, v.27, n.9, p.1033-1036, 1992.

MATTHEIJ, W.M.; EIJLANDER, R.; KONING, J.R.A.; LOUWES, K.M. Interspecific hybridization between the cultivated potato Solanum tuberosum subspecies tuberosum L. and the wild species S. circaeifolium subsp. Circaeifolium Bitter exhibiting resistance to Phytophthora infestans (Mont.) de Bary and Globodera pallida (Stone) Behrens. 1 - Somatic hybrids. Theoretical and Applied Genetics, v.83, p.459-466, 1992.

MAYEDA, L.Y. Estudo cariotípico de cinco espécies do gênero Passiflora (Passifloraceae). Piracicaba, 1994. 89p. Dissertação (Mestrado). Escola Superior de Agricultura Luiz de Queiroz, Universidade de São Paulo.

MC CONNELL, J.; KAMEMOTO, H. Morphology and meiotic behavior of three Dendrobium amphidiploids and their diploid counterparts. HortScience, v.28, n.9, p.935-937, 1993. 
MC GUIRE, P.E.; DVORAK, J. Genetics regulation of heterogenetic chromosome pairing in polyploid species of the genus Triticum. Canadian Journal of Genetics and Cytology, v.23, p.57-82, 1982.

MEDINA, J.C. In: Maracujá; da cultura ao processamento e comercialização. Campinas: ITAL. 1980. p.5-105.: Maracujá: cultura.

MELETTI, L. M. M.; SOARES-SCOTT, M. D.; BERNACCI, L. C.; PINTO-MAGLIO, C. A. F.; MARTINS, E. P. Caracterização agronômica e seleção de germoplasmas de maracujá (Passiflora spp). Revista Brasileira de Fruticultura. Cruz das Almas, Bahia, v.14, n.2, p.157-162, 1992.

MENKE, V.; SCHILDE-RENTSCHLER, C.; RUOSS, B.; ZANKE, C.; HEMLEBEN, N.V.; NINNEMANN, H. Somatic hybrids between the cultivated potato Solanum tuberosum L. and the 1EBN wild species Solanum pinnatisecum Dun:: morphological and molecular characterization. Theoretical and Applied Genetics, v.92, p.617-626, 1996.

NAGPAL, R.; RAINA, S. N.; SODHI, Y. S.; MUKHOPADHYAY, A.; ARUMUGAM, N.; PRADHAN, A. K.; PENTAL, D. Transfer of Brassica tournefortii (TT) genes to allotetraploid oilseed Brassica species (B. juncea AABB, B. napus, AACC, $B$. carinata $\mathrm{BBCC}$ ): homoeologous pairing is more pronounced in the three-genome hybrids (TACC, TBAA, TCAA, TCBB) as compared to allodiploids (TA, TB, TC). Theoretical and Applied Genetics, v.92, p.566-571, 1996.

OLIVEIRA, J. C. Melhoramento genético de Passiflora edulis Sims f. flavicarpa Deg. visando aumento da produtividade. Jaboticabal, 1980 (Tese de Livre Docência). Faculdade de Ciências Agrárias e Veterinarias/ Universidade do Estado de São Paulo. 
OLIVEIRA, J.C.; NAKAMUKA, K.; RUGGIERO, C.; FERREIRA, F.R. Determinação de fontes de resistência em Passifloraceae quanto à morte prematura de plantas. Summa Phytopathologica, v.9, p.64-65, 1983.

OLIVEIRA, J.C.; FERREIRA， F.R. ; RUGGIERO, C.; NAKAMURA K. Caracterização e avaliação de germoplasma de Passifloracea quanto à morte prematura de plantas. In: CONGRESSO PAULISTA DE FRUTICULTURA, 9., Campinas. Anais. SPF, 1987. p.591-596.

OLIVEIRA, J.C.; FERREIRA, F.R. Melhoramento genético do maracujazeiro. In: SÃO JOSÉ, A.R. ; FERREIRA, F.R.; VAZ, R.L. (Coord). A cultura do maracujá no Brasil. Jaboticabal, FUNEP, 1991. p.211-246.

OLIN-FATIH, M.; LANNÉR, C.; LINDGREN, H. Analysis of chromosome, mtDNA and cpDNA patterns in five somatic hybrids between Brassica alboglabra Bailey and Brassica campestris L. Euphytica, v.90, p.281-288, 1996.

OTONI, W.C., BLACKHALL, N.W.; D'UTRA VAZ, F.B.; CASALI, V.W.; POWER, J.B.; DAVEY, M.R. Somatic hybridization of the Passiflora species, P. edulis $\mathrm{f}$. flavicarpa Degener and P. incarnata L. Journal of Experimental Botany, v.46, n.288, p.777-785, 1995.

PAGLIARINI, M.S. Instabilidade meiótica em Thunbergia mysorensis (Acanthaceae). Brazilian Journal for the Advance of Science, v.42, n.1, p.83-87, 1989.

PAPA, R.C.R. Maracujá: morte prematura. Toda Fruta, v.46, p.19-21, 1990. 
PAROKONNY, A. S.; KENTON, A.; GLEBA, Y. Y.; BENNETT, M. D. The fate of recombinant chromosomes and genome interaction in Nicotiana asymmetric somatic hybrids and their sexual progeny. Theoretical and Applied Genetics, v.89, p.488497, 1994.

PAROKONNY, A.S.; MARSHALL, J.A.; BENNETT, M.D.; COCKING, E.C.; DAVEY, M.R.; BRIAN POWER, J. Homoeologous pairing and recombination in backcross derivatives of tomato somatic hybrids [Lycopersicon esculentum $(+) L$. peruvianum]. Theoretical and Applied Genetics, v.94, p.713-723, 1997.

PENTAL, D.; HAMIL, J. D.; PIRRIE, A.; COCKING, E.C. Somatic hybridization of Nicotiana tabacum and Petunia hybrida. Recovery of plants with $P$. hybrida nuclear genome and N. tabacum chloroplast genome. Molecular General Genetics, v.202, p.342-347, 1986.

PIJNACKER, L.P.; FERWERDA, M.A.; PUITE, K.J.; ROEST, S. Elimination of Solanum phureja nucleolar chromosome in $S$. tuberosum $+S$. phureja somatic hybrids. Theoretical and Applied Genetics, v.73, p.878-882, 1987.

PIJNACKER, L.P.; FERWERDA, M.A.; PUITE, K.J.; SCHAART, J.G. Chromosome elimination and mutation in tetraploid somatic hybrids of Solanum tuberosum and $S$. phureja. Plant Cell Reports, v.8, p.82-85, 1989.

PINTO, R.J.B Introdução ao melhoramento genético de plantas. Universidade Estadual de Maringá, Maringá, 1995, 275p.

PROJETO MARACUJÁ. Pará: Secretaria de Estado de Agricultura, p.23, 1977. 
PUITE, K.J.; ROEST, S.; PINNACKER, L.P. Somatic hybrid potato plants after electrofusion of diploid Solanum tuberosum and S. phureja. Plant Cell Reports, v.5, p.262-265, 1986.

PUPILLI, F.; SCARPA, G. M.; DAMIANI, F.; ARCIONI, S. Production of interspecific somatic hybrid plant in the genus Medicago through protoplast fusion. Theoretical and Applied Genetics, v.84, p.792-797, 1992.

PUPILLI, F.; BUSINELLI, S.; CACERES, M. E.; DAMIANI, F.; ARCIONI, S. Molecular, cytological and morpho-agronomical characterization of hexaploid somatic hybrids in Medicago. Theoretical and Applied Genetics, v.90, p.347-355, 1995.

RUGGIERO, C. (Ed). Cultura do maracujazeiro. Ribeirão Preto, Legis Summa, 1987. 250p.

RUGGIERO, C. Enxertia do maracujazeiro. In: SÃO JOSÉ, A. R., FERREIRA, F. R.; VAZ, R. L., (Ed) A Cultura do maracujá no Brasil. Jaboticabal: FUNEP, 1991. p 43-57.

SAS Institute Inc SAS/STAT. User's guide, Version 6.03. Cary, NC. 1988.

SIMMONDS, N.W. Genetical and cytological studies of Musa. $\mathrm{x}$ stomatal size and vigour in relation to polyploidy. Journal of Genetics, v.49, p.57-68, 1948.

SKARZHINSKAYA, M.; LANDGREN, M.; GLIMELIUS, K. Production of intertribal somatic hybrids between Brassica napus L. and Lesquerella fendleri (Gray) Wats. . Theoretical and Applied Genetics, v.93, p.1242-1250, 1996. 
SOUZA, J.S.I.; MELETTI, L.M.M.; Maracujá. Espécies, variedades, cultivo. Piracicaba: FEALQ, 1997. 179p.

STEBBINS, G.L. Variation and evolution in plants. Columbia University Press, New York, 1950.

SUNDENBERG, E; GLIMELIUS, K. Effects of parental ploidy level and genetic divergence on chromosome elimination and chloroplast segregation in somatic hybrids within Brassicaceae. Theoretical and Applied Genetics, v.83, p.81-88, 1991.

SUNDERLAND, N. Nuclear cytology. In: STREET, H.E. Plant tissue and cell culture. Oxford: Blackwell, 1977. p.177-205.

SUZUKI, D. T.; GRIFFITHS, A. J. \& LEWONTIN, R. C. An introduction to genetic analysis. New York: W.H. Freeman and Company, 1981. 911 p.

SYBENGA, J. Meiotic configurations. New York: Springer, 1975. $251 \mathrm{p}$.

SYBENGA, J.; SCHABBINK, E.; van EDEN, J.; JONG, J. H. de. Pachytene pairing and metaphase I configurations in a tetraploid somatic Lycopersicon esculentum X L. peruvianum hybrid. Génome, v.37, p.54-60, 1994.

TAGUCHI, T.; SAKAMOTO, K.; TERADA, M. Fertile somatic hybrids between Petunia hybrida and a wild species, Petunia variabilis. Theoretical and Applied Genetics, v.87, p.75-80, 1993.

TEIXEIRA, C.G. In: Maracujá. Campinas: ITAL, 1994, 267p. (Série frutas tropicais). 
THOMAS, H. M.; THOMAS, B. J. Synaptonemal complex formation in two allohexaploid Festuca species and a pentaploid hybrid. Heredity, v.71, p.305-311, 1993.

VANDERPLANCK, J. Passion Flowers. Cambridge Press, MIT, 1996. 224p.

VIEIRA, M.L.C. Hibridação somática em plantas: A importância das espáecies selvagens como fonte de genes. Biotecnologia - Ciência e desenvolvimento, n.1, p.36-40, 1997.

VIEIRA, M.L.C.; DORNELAS, M.C. Regeneration of plants from protoplast of Passiflora species (passion fruit). In: BAJAY, Y.P.S. (Ed.). Biotechnology in Agriculture and Foresty 38. Berlin: Springer-Verlag, 1996. cap. 10, p.108-119.

WIJBRANDI, J.; POSTHUMA, A.; KOK, J. M.; RIJKEN, R.; VOS, J.G.M.; KOORNNEEF, M. Asymmetric somatic hybrids between Lycopersicon esculentum and irradiated L. peruvianun. 1 - Cytogenetics and morphology. Theoretical and Applied Genetics, v.80, p.305-312, 1990.

WILLIANS, C.E.; HUNT, G.J.; HELGESON, J. P. Fertile somatic hybrids of Solanum species: RFLP analysis of a hybrid and its sexual progeny from crosses with potato. Theoretical and Applied Genetics, v.80, p.545-551, 1990.

WILLIANS, C.E.; WIELGUS, S.M.; HABERLACH, G.T.; GUENTHER, C.; KIMLEE, H.; HELGESON, J. P. RFLP analysis of chromosomal segregation in progeny from an interspecific hexaploid somatic hybrid between Solanum brevidens and $S$. tuberosum. Genetics, v.135, p.1167-1173, 1993. 
WINKS, C. W.; MENZEL, C. M.; SIMPSON, D. R. Passion fruit in Quensland: botany and cultivars. Journal Agricultural of Queesland, v.114, p.217, July/Aug. 1988.

WOLTERS, A.M.; SCHOENMAKERS, H.C.H.; KAMSTRA, S.; VAN EDEN, J.; KOORNNEEF, M.; JONG, J.H. Mitotic and meiotic irregularities in somatic hybrids of Lycopersicon esculentum and Solanum tuberosum. Génome, v.37, p.726-735, 1994.

WOLTERS, A.M.; JACOBSEN, E.; O' CONNELL, M.; BONNEME, G.; RAMULU, K.S.; JONG, H.; SCHOENMAKERS, H.; WUBRANDIL, J.; KOORNNEEF, M. Somatic hybridization as a toll for tomato breeding. Euphytica, v.79, p.265-277, 1994a.

YAMAGISHI, H.; HOSSAIN, M.M.; YONEZAWA, K. Morphology, fertility and cross-compatibility of somatic hybrids between Brassica oleracea L. and $B$. campestris L. Scientia Horticulturae, v.58, p.283-288, 1994.

YAMASHIRO, T.; LANDGRAFF, J.H. Maracujá-açú (Passiflora alata Ait), porta enxerto resistente à fusariose do maracujazeiro (Passiflora edulis var. flavicarpa Deg.) In: CONGRESSO BRASILEIRO DE FRUTICULTURA, 5. Pelotas. Anais. 1979. p.918-921. 
ANEXO 


\title{
Meiotic behavior of passion fruit somatic hybrids, Passiflora edulis $\mathbf{f}$. flavicarpa Degener + P. amethystina Mikan
}

\author{
L.V. Barbosa \& M.L.C. Vieira \\ Department of Genetics, Escola Superior de Agricultura 'Luiz de Queiroz', University of São Paulo, P.O. Box 83. \\ 13418-900, Piracicaba, SP, Brazil
}

Received 5 December 1996; accepted 18 July 1997

Ke words: passion fruit, Passiflora edulis f. flavicarpa, Passiflora amethystina, somatic hybridization, meiotic behavior, pollen viabilty

\section{Summary}

Somatic hybrids (SH) obtained by protoplast fusion were investigated for meiotic behavior in order to determine their possible use in breeding programs. Flower buds from four genotypes of $\mathrm{SH}$ between $P$. edulis $\mathrm{f}$. flavicarpa (E) and the wild species P. amethystina (Am) denoted SH (E + Am) \# 12, \# 13, \#28 and \# 35 were collected and the microsporocytes analysed. Meiotic phases showed the presence of abnormalities such as univalents, bivalents and quadrivalents, laggard chromosomes and anaphase bridges. At least 14 bivalents were observed in most of the cells of the hybrid plants. The percentage of cells with quadrivalents ranged from 73.3 in $(E+A m) \# 13$ to 93.3 in $(E+A m) \# 28$ and \# 35 . Analysis of pollen viability $(V)$ indicated $V=88.23 \%$ for $\# 12, V=83.86 \%$ for $\# 13, V=$ $84.20 \%$ for $\# 28$, and $V=72.90 \%$ for $\# 35$, and fruit development was observed. The high pollen viability, together with the multivalent pairing observed in the four somatic hybrids indicates that these materials can be used for the genetic improvement of yellow passion fruits aiming at introgressions of genes for resistance to diseases and pests.

\section{Introduction}

The family Passifloraceae consists of 12 genera. Within the family, Passiflora is the most species-rich genus, comprising approximately 400 species which are widely distributed in the tropical regions of South America (Killip. 1938; Snow \& MacDougal. 1993). Several species are important for their nutritional and pharmacological properties, but some of them are used as ornamental plants. According to Oliveira et al. (1988), more than 200 Passiflora species are native of Brazil, with the consequent presence of a wide genetic variability that can be exploited in breeding programs. This variability within the genus can be used by breeders in their efforts to improve traits related to flowering, productivity, resistance to pests and diseases. cold tolerance, and mainly fruit characteristics.

$P$. edulis f. flavicarpa, the yellow passion fruit, is the species of highest economic importance in the Americas, Australia and Africa (Oliveira, 1987). Brazil is the major worldwide producer. with an area of approximately 33,000 ha devoted to crop production (IBGE, 1993). The fruit is consumed fresh or processed for juice. Most of the commercial passion fruit varieties available are susceptible to a large number of pests and diseases with considerable negative effects on production. Genetic breeding programs aiming at the introgression of resistance genes are based on interspecific hybridization between the cultivated species $P$. edulis f. flavicarpa and wild species. However. self-incompatibility presents methodological difficulties (Knight Jr. \& Winters, 1962; Bruckner, 1993) and low fertility of the interspecific $F_{1}$ hybrids limits the use of certain breeding methods.

Somatic hybridization by protoplast fusion is an efficient method to overcome crossing barriers between sexually incompatible species and to increase the genetic variability of higher plants (Glimelius et al.. 1991: Lefrancois et al., 1993; Taguchi et al.. 1993: Fahleson et al., 1994; Parokonny et al.. 1994; Yamagishi et al.. 1994; Otoni et al., 1995). Protoplast fusion experiments have shown that somatic hybrids may 

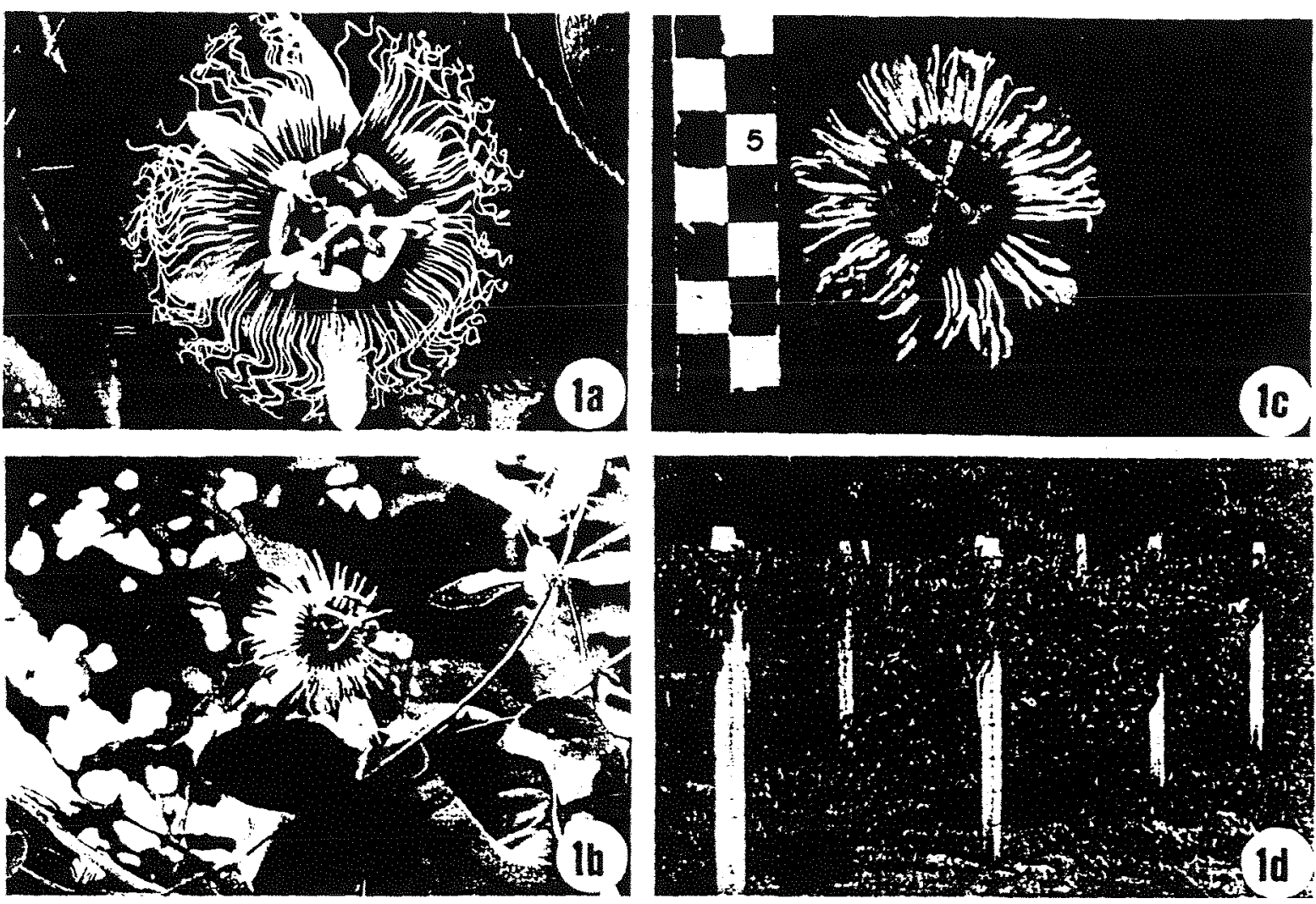

Figure 1. Flower morphology of the parental species. P. edulis f. flavicarpa (a). P. amethystina (b). and their somatic hỵbrid (c). Hýbrid plants in the field (d).

have variable chromosome numbers and the regenerated plants may range from self-fertile to highly sterile (Lefrancois et al., 1993). The combination of unrelated genomes may cause the elimination of parental chromosomes. Chromosome elimination is usually incomplete for related species, so that it is possible to introduce certain genetic traits into the cultivated species.

De Jong et al. (1993) reported that somatic hybridization is useful only when it is possible to perform backcrossing with the recurrent parental line. The occurrence of meiotic recombination between homoeologous chromosomes is also essential for the success of the technique. Unlike in sexual hybrids. the parents of a somatic hybrid contribute diploid sets of chromosomes. Consequently, if there is no pairing between the homoeologues, that is, between the sets of chromosomes contributed by the parents. a somatic hybrid will behave like a perfect diploid and will form only bivalents in metaphase I. Therefore. it will be stable and should be fertile but introgressions from one species nto the other can only be in the form of whole chronosome substitutions: introgressions of small chromo- some segments via crossing over are precluded by the lack of pairing. On the other hand, if sufficient affinity of the parental genomes exists or pairing control is lax enough to permit meiotic pairing of homoeologues, meiotic stability will decrease because of the formation of multivalents and fertility may be reduced. but small introgressions from one species into the other will be possible.

Moreover, Lefrancois et al. (1993) recommend a comparative study of the meiotic behavior of sexual hybrids, somatic hybrids and parental forms. Information about the chromosome arrangements and mechanisms involved in recombination would be of great importance for the selection process and for the production of hybrid progenies of interest.

Regarding yellow passion fruit, reports towards somatic hybridization are already available (Dornelas et al.. 1995: Otoni et al.. 1995: Vieira \& Dornelas. 1996). Dornelas et al. (1995) obtained somatic hybrids $(4 n=4 x=36)$ via chemical protoplast fusion between $P$. edulis $\mathrm{f}$. Aavicarpa $(2 \mathrm{n}=2 \mathrm{x}=18)$ and four wild diploid species. including $P$. amethystina $(2 \mathrm{n}=2 \mathrm{x}=$ 


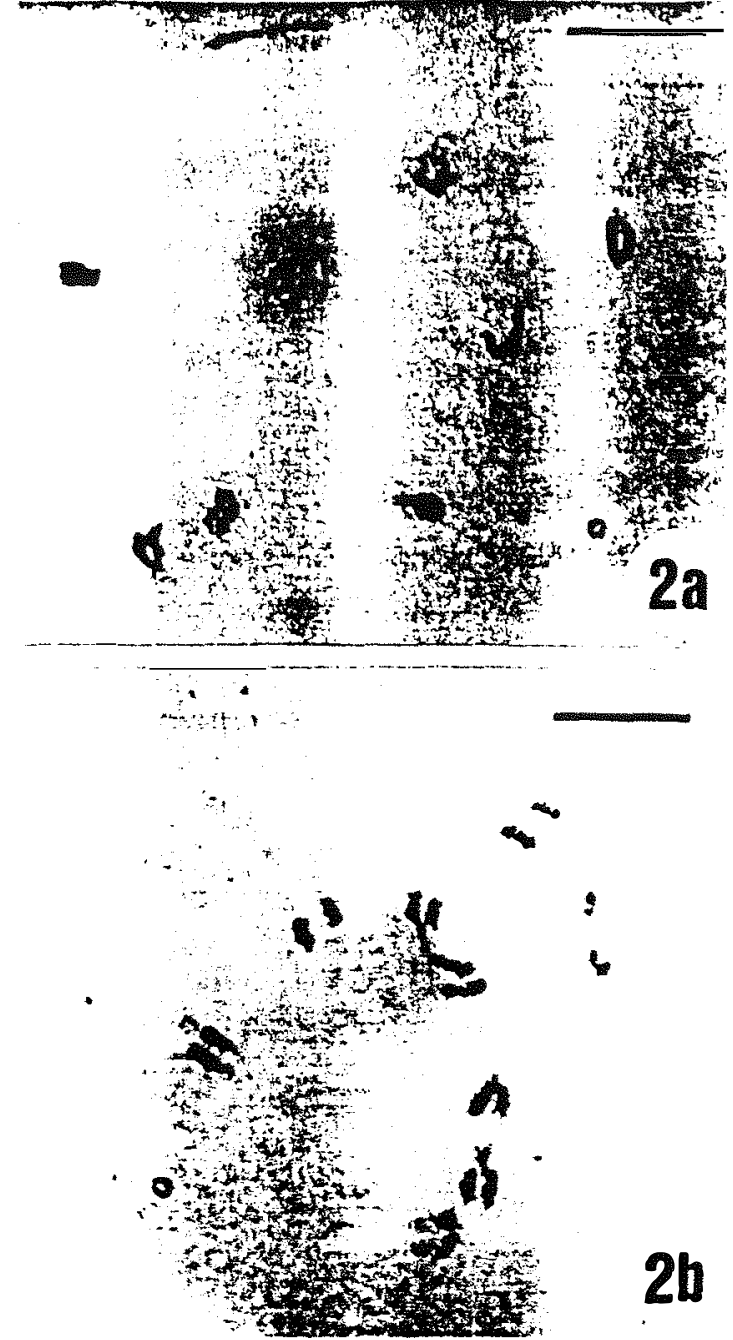

Figure 2. Pollen mother cell of $P$. edulis f. flasicarpa (a) and $P$. amethysina (b) at diakinesis stage with normal sinapsis forming 9 bivalents. Two of them are associated with the nucleolus in $P$. amethistina. Bars represent $10 \mu \mathrm{m}$.

18). aiming at the introgression of alien genes such as the one that confers resistance to Xanthomonas campestris $\mathrm{f}$. passiflora. As the technique has a high potential for passion fruit improvement the objective of the present study was to assess the meiotic behavior of parental forms and the four corresponding somatic hybrid plants obtained by protoplast fusion between $P$. edulis t. flavicarpa and $P$. amethystina. A knowledge of their meiotic behavior and pollen viahility, aids in planning a more efficient use of these somatic hybrids as a bridge between the alien and crop species.

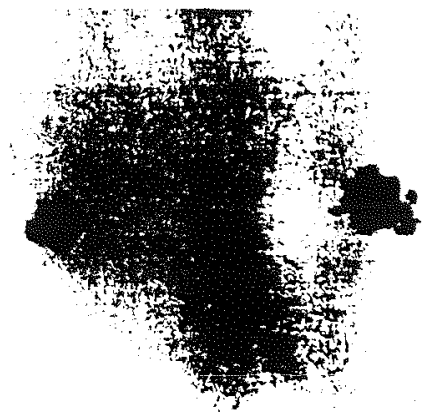

\section{3a}

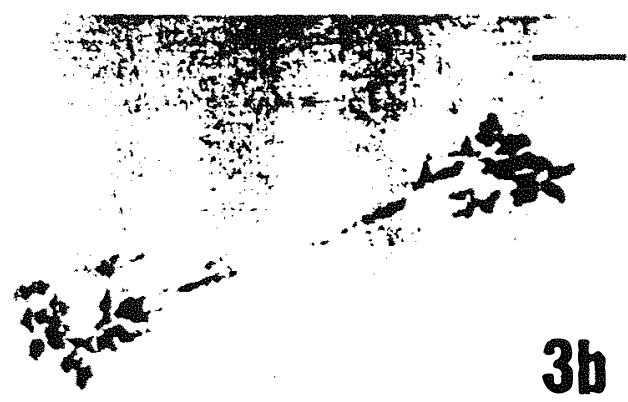

Figure 3. Presence of laggard chromosomes (a) and the occurrence of a chromosome bridge $(b)$ in $\mathrm{SH}(E+A m)=12$. Bars represent $10 \mu \mathrm{m}$.

\section{Material and methods}

Biological material used in the present study consisted of two diploid species, $P$. edulis f. flaricarpa $(2 \mathrm{n}=18)$ [E] and $P$. amethystina $(2 \mathrm{n}=18)[\mathrm{Am}]$ and their four somatic hybrids $(4 n=36)$ denoted $(E+A m) \# 12$, \#13, \# 28 and \# 35 (Figure 1). The plants were produced by chemical protoplast fusion (Dornelas et al., 1995). The parental forms and the somatic hybrid plants were transferred to the field where both produced flowers and set fruit between October 1995 and May 1996. The leaf and flower characteristics of the hybrids were intermediate relative to the parents.

Flower buds were collected, fixed in Carnoy $(3: 1$. ethanol: glacial acetic acid) for 24 hours. transferred to $70 \%$ ethanol $(\mathrm{v} / \mathrm{v})$ and stored at $5{ }^{\circ} \mathrm{C}$. Mficrosporocytes were prepared by the standard smear technique and stained with $2 \%$ propionic carmine (IN $\cdots$ ). All phases of meiosis were investigated including alterations such as laggard chromosomes on the metaphase plate and anaphase bridges.

For segregation analysis. 30 cells were studied in the diakinesis for each plant recording the presence of univalents, bivalents and multivalents. Pollen viability (V) was determined by the method described by 
Tahle 1. Meiotic analysis of $P$. edulis [E]. P. amethvstina $[\mathrm{Am}]$ and their four somatic hybrids $(\mathrm{E}+\mathrm{Am}) \# 12, \# 13, \# 28$ and \# 35. showing laggard chromosomes and anaphase bridges

\begin{tabular}{|c|c|c|c|c|c|c|}
\hline Materials & $\begin{array}{l}\text { Laggard } \\
\text { chromosomes' }\end{array}$ & $\begin{array}{l}\text { Laggard } \\
\text { chromosomes }^{2}\end{array}$ & $\begin{array}{l}\text { Laggard } \\
\text { chromosomes }\end{array}$ & $\begin{array}{l}\text { Laggard } \\
\text { chromatids }\end{array}$ & $\begin{array}{l}\text { Chromosome } \\
\text { bridges }^{5}\end{array}$ & $\begin{array}{l}\text { Chromatid } \\
\text { bridges }^{6}\end{array}$ \\
\hline P. edulis & 0.99 & 0.38 & 0.00 & 0.00 & 0.65 & 0.25 \\
\hline P. amethystina & 0.44 & 0.68 & 0.00 & 0.00 & 0.79 & 0.23 \\
\hline$(E+A m) \# 12$ & 1.15 & 2.47 & 0.00 & 0.00 & 2.12 & 7.11 \\
\hline$(E \div A m) \# 13$ & 5.90 & 4.10 & 0.00 & 1.92 & 3.83 & 4.39 \\
\hline$(E+A m) \# 28$ & 1.15 & 1.15 & 0.00 & 0.00 & 2.09 & 1.37 \\
\hline$(E+A m) \# 35$ & 8.11 & 13.16 & 7.57 & 3.95 & 12.37 & 16.05 \\
\hline
\end{tabular}

1,2 Percentage of laggard chromosomes at metaphases I and II, respectively.

$3 .{ }^{4}$ Percentage of laggard chromosomes and chromatids at anaphases I and II, respectively.

5,6 Percentage of chromosome and chromatid bridges at anaphases I and II, respectively.

Table 2. Meiotic analysis of the somatic hybrids $(E+A m) \# 12 . \# 13, \# 28$ and \#35. Number of cells analyzed $=30$ (data in \%)

\begin{tabular}{|c|c|c|c|c|c|c|c|c|}
\hline Materials & $12 I I+4 I+2 I V$ & $13 I I+2 I+2 I V$ & $14 I I+41+1 I V$ & 14 II + 2 IV & $15 I I+2 I+1 I V$ & $16 I I+I V$ & $17 \mathrm{II}+2 \mathrm{I}$ & 1811 \\
\hline \multicolumn{9}{|c|}{$\mathrm{SH}(E+A m)$} \\
\hline$\# 12$ & 3.3 & 0.0 & 3.3 & 26.7 & 10.0 & 40.0 & 10.0 & 6.7 \\
\hline \multicolumn{9}{|c|}{$\mathrm{SH}(E+A m)$} \\
\hline$\# 13$ & 0.0 & 0.0 & 0.0 & 16.7 & 13.3 & 43.3 & 6.7 & 20.0 \\
\hline \multicolumn{9}{|c|}{$\mathrm{SH}(\mathrm{E}+\mathrm{Am})$} \\
\hline$\# 28$ & 0.0 & 0.0 & 0.0 & 30.0 & 20.0 & 43.3 & 0.0 & 6.7 \\
\hline \multicolumn{9}{|c|}{$\mathrm{SH}(E+\mathrm{Am})$} \\
\hline$\# 35$ & 0.0 & 3.3 & 0.0 & 40.0 & 23.3 & 26.7 & 6.7 & 0.0 \\
\hline
\end{tabular}

Alexander (1980). Statistical analysis were conducted using Shapiro-Wilk statistical test from SAS program (SAS Institute Inc.).

\section{Results and discussion}

Meiotic analyses of the parental species $(2 n=18)$ showed the presence of 9 bivalents (Figure 2). In $P$. edulis $\mathrm{f}$. flavicarpa two bivalents were associated with the nucleolus in $67 \%$ of the cells and one bivalent was associated with the nucleolus in $33 \%$ of the cells, indicating the presence of two nucleolarorganizingregions (NOR's). In P. amethystina, two bivalents were associated with the nucleolus in all cells analyzed. These observations confirm the data reported previously by Mayeda \& Vieira (1994). According to this report, there are two Ag-stained NOR's in $P$. edulis f. flavicarpa, one located at the secondary constrictions of chromosome 8 and another at the small satellites of chromosome 9 .

Chromosome pairing in the parental species was regular, although some laggard chromosomes and anaphase bridges were observed (less than $1{ }^{\circ} i$ ). The analysis of somatic hybrids showed $4 n=36$ chromosomes; no aneuploids were present. Four NOR's were observed, confirming the hybrid nature of the material.

In the somatic hybrids, meiosis was irregular with high frequencies of bridges and laggards in both divisions (Table 1 and Figure 3). Clear differences in the meiotic behavior among the hybrids were observed. The hybrids $(E+A m) \# 12$ and \# 28 had more regular meiosis than $(E+A m) \# 13$ and \# 35 .

Meiotic figures in hybrid cells display mostly bivalents and a few univalents or multivalents. The configurations observed at diakinesis are presented in Table 2 and Figure 4. At least $14 \mathrm{II}$ were observed in $96.7 \%$ of the cells of the hybrids $(E+A m) \# 12$ and \# 35 meanwhile, the same minimum of bivalents was detected in $100 \%$ of the cells of the hybrids $(E+A m) \# 13$ and \# 28 . As expected, the two sets of pairs of homologous chromosomes pair preferentially in the hybrids. According to McConnell \& Kamemoto (1993) the preponderance of bivalents reflects the level of homology between the parental chromosomes. Moreover, the frequencies of cells with quadrivalents were 73.3 in $(E+A m) \# 13$. 

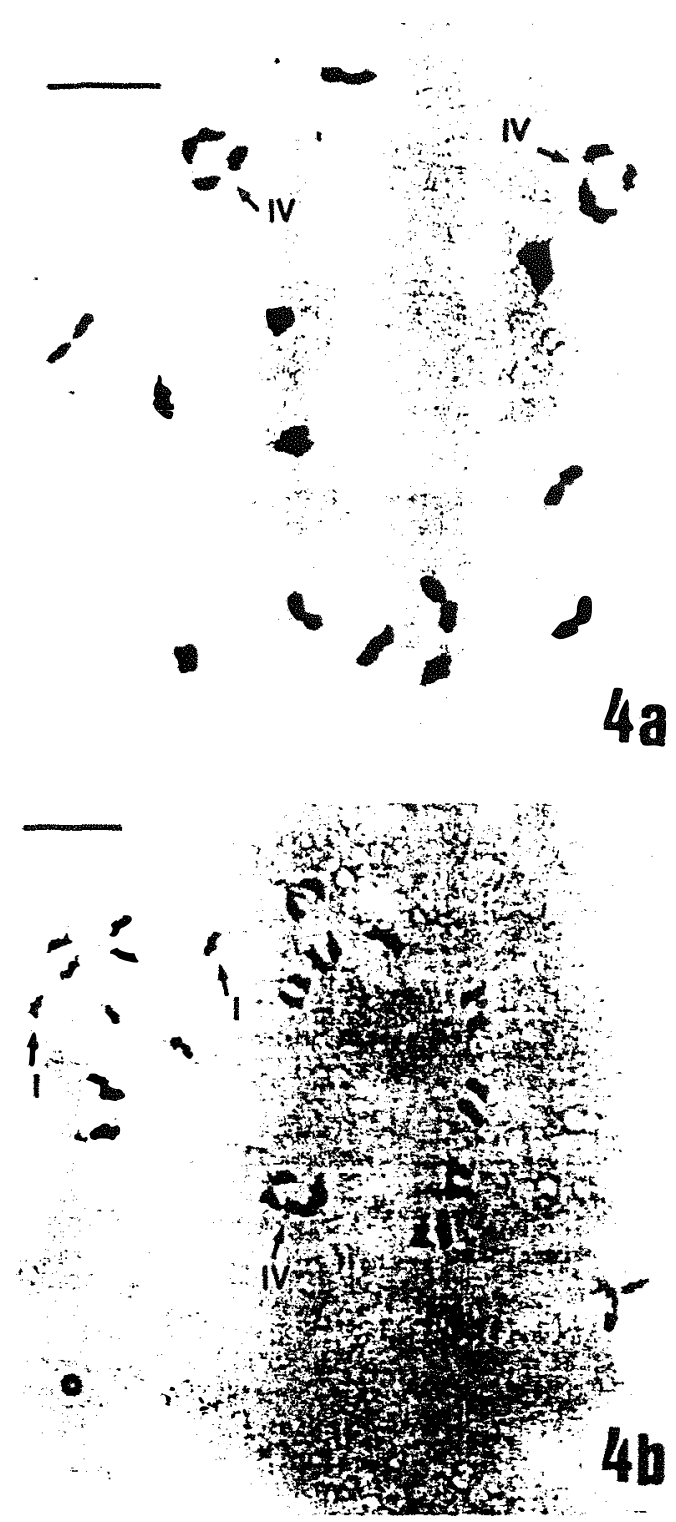

Figure 4. Pollen mother cell of $S H(E+A m) \# 12$ showing: a) 14 bivalents and wo quadrivalents (arrows, IV) and. b) two unis alents (arrows. 1). 15 hivalents and one quadrivalent (arrow. $11 \%$. Bars represent $10 \mu \mathrm{m}$.

83.3 in $\# 12$ and. $93.3 \%$ in $(E+A m) \# 28$ and $\# 35$. Multivalent formation indicates recombination that is indispensable to produce gene introgressions from one species to another.

Hybrid \# $2 S$ shows the lowest number of bridges in anaphase cells (I and II) and laggard chromosomes. The hybrid $(E+A m)$ \# 35 differs from the other three, by the largest number of cells with univalents (33.3\%) which explains the high level of laggard chromosomes and chromatids in the subsequent division

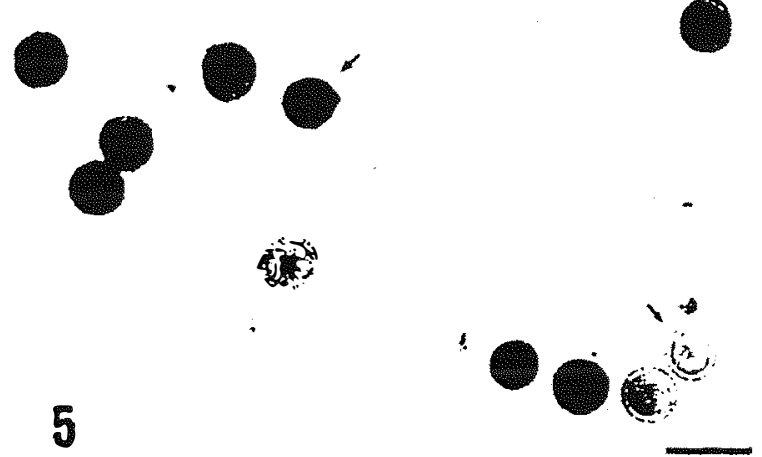

Figure 5. Pollen viability in $S H(E+A m) \# 13$. Bars correspond to $100 \mu \mathrm{m}$.

stages (Table 1). In five somatic hybrids between Brassica alboglabra and $B$. campestris produced through chemical protoplast fusion, Olin-Fatih et al. (1996) also found that all had aberrations. such as bridges and laggards regardless of differences in chromosome number and segregation pattern.

The present data support that recombination of the chromosomes of the two parental species occurred in the hybrids, mainly in the hybrid \# 28 and \# 35 . since most of their cells showed the occurrence of quadrivalents. In view of the presence of quadrivalents in all hybrid genotypes analyzed, $P$. edulis f. flasicarpa and $P$. amethystina may possess some chromosome homoeology. It is interesting to note that $P$. edulis $\mathrm{f}$. flavicarpa and $P$. amethystina show very similar karyotypes (Mayeda \& Vieira, 1994).

Analysis of pollen viability (V) of the two species under study and of their somatic hybrids and the $t$ test for comparison of the means are presented in Table 3. On average. all the materials analyzed presented high levels of pollen viability. The hybrid (\# 35 i showing the lowest mean viability (72.9\%) is the one which presents the higher percentage of meiotic irregularities. In contrast, the high levels of mean viability found for the parental species and the remaining hybrids analyzed (Figure 5) were related to the low percentage of meiotic irregularities observed (Table 1). The correlations between pollen viabilities and meiotic irregularities were high and negative (Figure 6).

Yamagishi et al. (1994). in a study of somatic hybridization involving the species Brassica oleraceac and $B$. campestris, also detected high pollen i iabilit! in the hybrids ( $88 \%$ on average). Many of the hubrids 

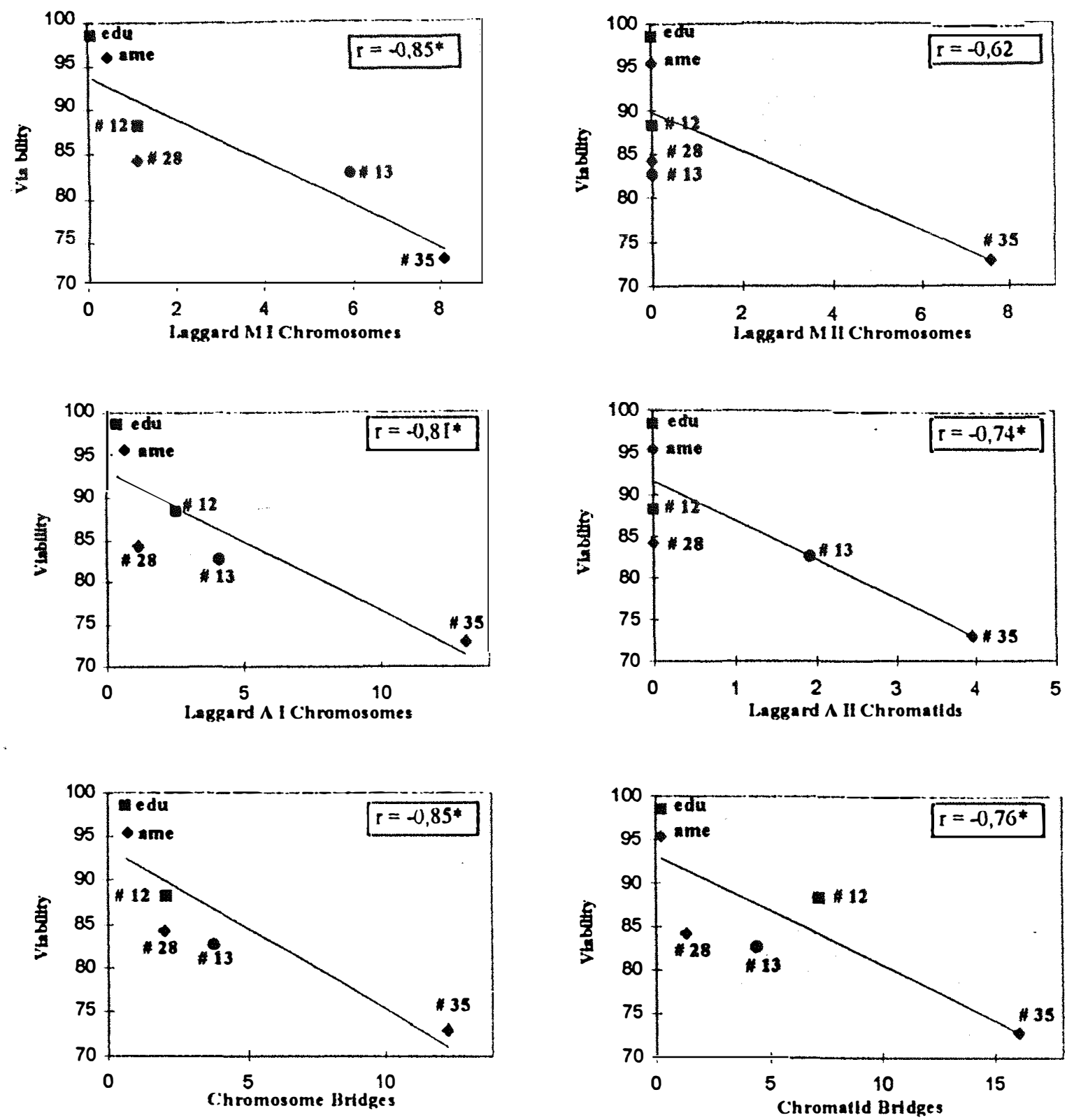

Figure 6. Correlations $(\mathrm{r})$ between mean pollen grain viabilities and meiotic irregularities observed in $P$. edulis (edu). P. ameth stina (ame) and their somatic hybrids $\mathrm{SH}(E+\mathrm{Am}) \# 12, \# 13, \# 2 \delta$ and \#35. "Significant at the $5 \%$ level of probability.

obtained by protoplast fusion between sexually incompatible species have shown low fertility and some of them were completely sterile, a fact that impairs their use in genetic breeding programs (Taguchi ct al.. 199.3). However. the high pollen viability observed in the present study and, mainly multivalent pairing in the hvbrids indicates that these materials can be used for the genetic improvement of yellow passion fruits aim- ing at the introgression of genes for resistance to diseases and pests.

\section{Acknowledgements}

The authors are grateful to Fundacão de Amparo à Pesquisa do Estado de São Paulo (FAPESP, grant 
Table 3. Percentage of pollen viability and t test for the comparison of mean pollen grain viabilities of $P$. edulis [E], P. amethystina $[\mathrm{Am}]$ and their four somatic hybrids $(\mathrm{E}+\mathrm{Am}) \# 12, \# 13$. \#28 and \#35

\begin{tabular}{|c|c|c|c|c|c|c|}
\hline & P. edulis & P. amethystina & $(E+A m) \# 12$ & $(E+A m) \# 13$ & $(E+A m) \# 28$ & $(E+A m) \# 35$ \\
\hline P. edulis & $98.48 \pm 0.96^{1}$ & $3.05^{* *}$ & $10.25^{* *}$ & $15.80^{* *}$ & $14.28^{* *}$ & $25.58^{* *}$ \\
\hline P. amethystina & & $95.43 \pm 1.02^{1}$ & $7.20 * *$ & $12.75^{* *}$ & $11.23^{* *}$ & $22.53^{* *}$ \\
\hline$(E+A m) \# 12$ & & & $88.23 \pm 1.07^{1}$ & $5.55^{* *}$ & $4.03^{* *}$ & $15.33^{*}$ \\
\hline$(E+A m) \# 13$ & & & & $82.68 \pm 3.83^{1}$ & $1.52 \mathrm{n}^{3}$ & $9.78^{*}$ \\
\hline$(E+A m) \# 28$ & & & & & $84.20 \pm 5.50^{1}$ & $11.30^{n s}$ \\
\hline$(E+A m) \# 35$ & & & & & & $72.90 \pm 11.02^{t}$ \\
\hline
\end{tabular}

I Percentage of pollen viability.

$n s$ Nunsignificant.

- Significant at the $5 \%$ level of probability.

- Significant at the $1 \%$ level of probability.

95/3029-0) for financial support. Dr. Antonio Augusto Franco Garcia for helping in the statistical analysis and Mr. Carlos Alberto de Oliveira for technical assistance.

\section{References}

Alexander. M.P.. 1980. A versatile stain for pollen from fungi, yeast and bacteria. Stain Technology 55: 13-18.

Bruckner. C.H.. 1993. Auto incompatibilidade no maracus̆ (Passiflora edulis Sims). Vicosa, 85 p. (Doctoral thesis, Universidade Federal de Vicosa).

De Jong. J.H.. A.M.A. Wolters, J.M. Kok, H. Verhaar \& J. van Eden. 1993. Chromosome pairing and potential for intergeneric recombination in some hypotetraploid somatic hybrids of Lycopersicon esculentum (+) Solanum tuberosum. Genome 36: 1032-1041.

Dornelas. M.C., F.C.A. Tavares, J.C. de Oliveira \& M.L.C. Vieira, 1995. Plant regeneration from protoplast fusion in Passiflora spp. Plant Cell Rep 15: 106-110.

Fahleson. J.. I. Erikson, M. Landgren \& K. Glimelius, 1994. Intertribal somatic hybrids between Brassica napus and Thlapsi per. foliatum with high content of the T. perfoliatum specific nervonic acid. Theor Appl Genet 87: 795-804.

Glimelius. C.. J. Fahlesson. M. Landgren, C. Sjodin \& E. Sundberg. 1991. Gene transfer via somatic hybridization in plants. Tibtech 9: 24-30.

Killip. E.P. 1938. The American Species of Passifloraceae. Field Museum of Natural History. Chicago.

Knight R.J. Jr.. H.F. Winters. 1962. Pollination and fruit set of yellow passion fruit in Southern Florida. Proceedings of the Florida State. Horticultural Soc 75: 412-418.

IBGE. 1993. Producão agrícola municipal. Rio de Janeiro. p. 53 (Instituto Brasileiro de Geografia e Estafstica, Anuário Estatistico do Brasil).

Lefrancois. C..J.P. Chupeau \& J.P. Bourgin. 1993. Sexual and somatic hy'bridization in the genus Lycopersicon. Theor Appl Genet S6: $533-5+6$.
Mayeda, L.Y. \& M.L.C. Vieira. 1994. Estudo carioúpico de cinco espécies do gènero Passiflora (Passifloraceae). Brazilian J Genet 17: 160 (Supplement).

McConnell, J. \& H. Kamemoto, 1993. Morphology and meiotic behavior of three Dendrobium amphidiploids and their diploid counterparts. HortScience 28: 935-937.

Olin-Fatih, M.. C. Lannér \& H. Lindgren, 1996. Analysis of chromosome, mtDNA and cpDNA patterns in five somatic hybrids between Brassica alboglabra Bailey and Brassica campestris $\mathrm{L}$. Euphytica 90: 281-288.

Oliveira, J.C. de. 1987. Melhoramento gerítico. In: C. Ruggiero (Ed.), Maracujá. Vol 1, pp. 218-246. Editora Legis Summa, Ribeiräo Preto.

Oliveira, J.C. de. P.E. Camier \& G.M. Assis de, 1988. Preservac̄o de germoplasmas de maracujazeiros. In: Encontro sobre Recursos Genéticos, p. 200. Anais. Jaboticabal. FCAVJ.

Otoni, W.C., N.W. Blackhall, F.B. d'Utra Vaz, V.W. Casali, J.B. Power \& M.R. Davey, 1995. Somatic hybridization of the Passiflora species. $P$. edulis $\mathrm{f}$. flavicarpa Degener and $P$. incarnata $\mathrm{L}$. J Exp Bot 46: 777-785.

Parokonny, A.S.. A. Kenton, Y.Y. Gleba \& M.D. Bennett, 1994. The fate of recombinant chromosomes and genome interaction in Nicotiana asy'mmetric somatic hybrids and their sexual progeny. Theor Appl Genet 89: 488-497.

Snow, N. \& J.M. MacDougal, 1993. New chromosome reports in Passiflora (Passifloraceae). Syst Bot 18: 261-273.

Taguchi, T., K. Sakamoto \& M. Terada, 1993. Fertile somatic hybrids between Petunia hybrida and a wild species, Petunia variabilis. Theor Appl Genet 87: 75-80.

Vieira, M.L.C. \& M.C. Domelas, 1996. Regeneration of plants from protoplasts of Passiflora species (passion fruit). In: Y.P.S. Bajaj (Ed.), Biotechnology in Agriculture and Forestry, Vol 38, pp. 108-119. Springer-Verlag, Berlin Heidelberg.

Yamagishi, H., M..M. Hossain \& K. Yonezawa. 1994. Morphology, fertility and cross-compatibility of somatic hybrids between Brassica oleracae L. and B. campestris L. Scientia Horticulturae 58: 283-288. 